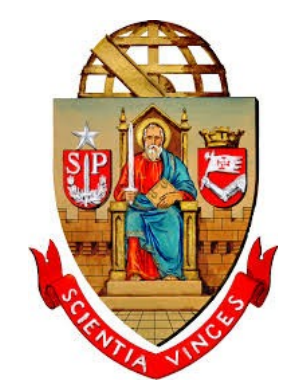

\author{
UNIVERSIDADE DE SÃO PAULO \\ ESCOLA DE COMUNICAÇÕES E ARTES \\ PROGRAMA DE PÓS-GRADUAÇÃO EM ARTES CÊNICAS
}

VICTOR PAULO DE SEIXAS

\title{
Repetir e sentir: \\ Mimo Corpóreo, treinamento \\ e subjetividade
}




\section{VICTOR PAULO DE SEIXAS}

\section{Repetir e sentir: \\ Mimo Corpóreo, treinamento \\ e subjetividade}

Dissertação apresentada à Escola de Comunicações e Artes da Universidade de São Paulo, para obtenção do Título de Mestre em Artes.

Área de Concentração: Pedagogia do Teatro, Formação do Artista Teatral

Orientador: Prof. Dr. Eduardo Tessari Coutinho

São Paulo

2016 
SEIXAS, V. P. Repetir e sentir: Mimo Corpóreo, treinamento e subjetividade.

Dissertação apresentada à Escola de Comunicações e Artes da Universidade de São Paulo para obtenção do Título de Mestre em Artes.

Aprovado em: 


\section{Banca Examinadora:}

Prof. Dr. Instituição:

Julgamento:

Assinatura:

Prof. Dr.

Instituição:

Julgamento:

Assinatura:

Prof. Dr. Instituição:

Julgamento:

Assinatura: 


\section{AGRADECIMENTOS:}

À minha família e em especial para minha mãe Eulici Guimarães por todo o suporte.

Ao Prof. Dr. Eduardo Tessari Coutinho pela paciência na orientação e incentivo que tornaram possível à conclusão desta dissertação.

Agradeço também à todos os professores que me acompanharam durante o processo, em especial à Prof. Dra. Andréia Nhur, à Prof. Dra. Helena Bastos e ao Prof. Dr. George Mascarenhas, que ajudaram na realização deste trabalho.

À Rose Prado pelo apoio e o carinho no início dessa jornada.

Aos amigos, Bruno di Trento, Vânia Leite e Noêmia Scaravelli, que fizeram parte desses momentos sempre me ajudando e incentivando.

A todos os participantes do CEPECA(Centro de Pesquisa em Experimentação Cênica do Ator, ECA/USP) pelas trocas e o diálogo profícuo.

À Denise Namura e Roberto Audio pelas conversas.

Aos participantes do grupo de estudos:

Adriano Cavalcante, Andressa Nishiyama, Chico Américo, Joyce Nogueira, Ella Martines, Isabelle Carneiro Soares, Maico Santos Silveira, Rafael Markez, Thiara Borborema e Yluska Gaião. 


\section{RESUMO:}

SEIXAS, V. P. Repetir e Sentir: Mimo Corpóreo, treinamento e subjetividade. 2016. 114 f. Dissertação (Mestrado) - Escola de Comunicações e Artes, Universidade de São Paulo, São Paulo, 2016.

Esta pesquisa teórico-prática parte da análise da técnica do Mimo Corpóreo buscando procedimentos para auxiliar a sua aplicação na criação cênica e na formação de atores e mimos. Este estudo é influenciado pelo conceito de paralelismo ${ }^{1}$ proposto pelo filósofo Holandês Baruch de Espinosa onde a mente e corpo não apresentam uma relação causal, e sim uma relação de reciprocidade, esse princípio também serve como poética para a execução da parte prática da pesquisa.

Espinosa indo contra a tradição dualista propõe em sua doutrina filosófica uma união substancial entre corpo e mente, os dois são a mesma substância se manifestando em modos ${ }^{2}$ distintos agindo juntos pelo paralelismo. Levamos essa indicação para o processo de treinamento: mente e corpo trabalhando juntos sem relação hierárquica.

Levantamos reflexões sobre a prática do Mimo Corpóreo na formação de atores e mimos e para a criação cênica, estudando a questão da repetição dos exercícios dentro do treinamento corporal. Propomos também uma organização de procedimentos da técnica e uma análise de sua parte conceitual. Realizando um exercício cênico inspirado nos elementos da doutrina filosófica de Espinosa, que será apresentado junto com a conclusão.

Desta forma, procuramos fomentar a reflexão sobre o legado do ensino do Mimo Corpóreo e as suas possíveis aplicações também a outros processos criativos e de formação dentro das artes cênicas.

\section{PALAVRAS-CHAVE:}

Mímica Corporal Dramática; Teatro físico; Processo pedagógico; Etienne Decroux; Mimo Corpóreo; corpo e mente; Composição corporal; e Teatro.

1. Referente a relação extensão (corpo) e pensamento (mente), pela qual não há relação de causalidade ou de hierarquia entre os dois. A relação entre um e outro não é de causalidade, mas de expressão e simples correspondência, pois o que se passa em um deles exprime-se no outro: a mente e o corpo expressam a mesma coisa, cada um como um modo próprio e simultaneamente.

2. Modo ou afecção da substância, que é na substância e por ela se concebe (SPINOZA, 2009.P13). Onde uma consequência que já podemos adiantar: toda coisa singular é modo, e por outro lado, nem todo modo é coisa "singular", pois Espinosa conceberá modos infinitos imediatos e mediatos. 
SEIXAS, V. P. Repeat and feel: Mime Corporeal, training and subjectivity. 2016. $114 \mathrm{f}$. Thesis (MA) - Escola de Comunicação e Artes (USP), University of São Paulo, São Paulo, 2016.

This is a practical/theoretical research, starting from the analysis of Corporeal Mime technique, seeking for procedures to be used in scenic creation and training processes for actors and mimes. This study is influenced by the concept of parallelism proposed by the Dutch philosopher Baruch Spinoza, where the mind and body do not have a causal relationship, but a relationship of reciprocity, this principle also comes as poetic element on the practical part of this research.

Spinoza against the dualist tradition propose in his philosophical doctrine a substantial union between body and mind. The two here are the same substance manifesting in different ways, and acting together within the parallelism. We bring this statement to the training process: mind (subjectivity) and body (form) working together with no hierarchical relationship.

Raising some questions about the practice of the Corporeal Mime training applied for actors, mimes and the scenic creation, by the study the repetition issue on the in body training exercises, we also propose an organization of technical procedures and analysis of the conceptual part. Building a scenic exercise inspired in Spinoza"s philosophical doctrine, which will be show together with the conclusion.

In this way, we are looking here to promote the debate on the legacy of Corporeal Mime teaching, by proposing some possible applications on creative processes and actor/dancing training in the performing arts.

\section{KEY WORDS}

Corporeal Mime, physical theater, pedagogical process, Etienne Decroux, Dramatic Corporeal Mime, body and mind, body composition, theater. 


\section{SUMÁRIO:}

1. Introdução.

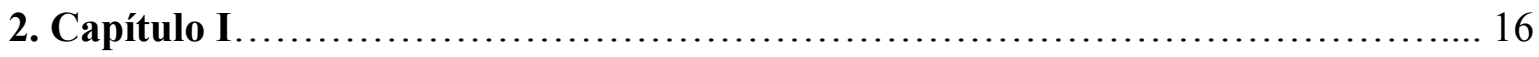

2.1 A redescoberta do corpo no século XX................................ 16

2.2 Jacques Copeau..................................................... 17

2.3 Etienne Decroux..................................................... 20

2.3.1 $\mathrm{O}$ artista.................................................... 20

2.3.2 O pedagogo................................................. 22

2.3.3 A Mímica Corporal de Decroux................................. 27

3. Capítulo II ............................................................ 37

3.1 Sobre o corpo.................................................... 37

3.2 O Corpo como identidade........................................ 38

3.2.1 Uma única substância...................................... 41

3.2.2 Paralelismo.................................................. 43

3.2.3 A ideia do corpo.............................................. 44

$3.3 \mathrm{O}$ corpo não é uma ferramenta.................................... 46

3.4 A Aplicação do paralelismo ao treinamento............................... 49

3.5 Repetir e Sentir.................................................. 50

4. Capítulo III ......................................................... 58

4.1 Sobre o Mimo Corpóreo..................................................... 58

$4.2 \mathrm{O}$ uso do véu no treinamento....................................... 78

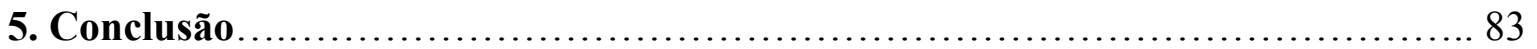

5.0.1 Onde trilhamos?.......................................... 83

5.0.2 O que fizemos?.............................................. 84

5.0.3 O que encontramos?......................................88

5.1 Conceitos desenvolvidos e explorados durante o processo................... 89

5.2 Uma trilogia para criação........................................... 90

6. Referências Bibliográficas ............................................... 94 


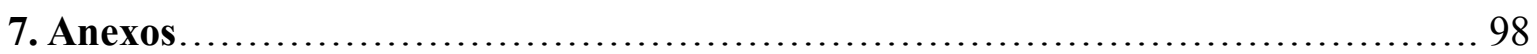

7.1 Ações de divulgação do Mimo Corpóreo no Brasil............................ 98

7.2 O Projeto Mímicas................................................. 98

7.2.1 Mostra de Mímica Contemporânea................................. 99

7.3 Entrevista com George Mascarenhas................................... 105

7.4 Entrevista com Ana Teixeira..........................................117

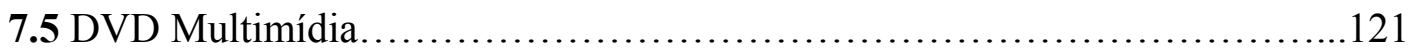

\section{Índice das imagens:}

Figura 1 - Etienne Decroux.

Figura 2 - Jacques Copeau.

Figura 3 - Jean-Louis Barrault: La Mort.

Figura 4 - Charles Dullin.

Figura 5- Casa/estúdio de Decroux em Boulogne-Billancourt (Paris).

Figura 6 - Cavalo marinho desenhado por Decroux.

Figura 7 - Divisão Corporal.

Figura 8 - Escala lateral do corpo (quadril e torre).

Figura 9 - Escala lateral do corpo (cabeça, pescoço, peito e cintura).

Figura 10 - Corpo tridimensional.

Figura 11 - Posições das mãos.

Figura 12 - Oitavos.

Figura 13 - Ponto fixo no espaço.

Figura 14 - Encontros do grupo de estudos 2014/2015.

Figura 15 - Treinamento do grupo de Estudos.

Figura 16 - Victor Seixas no espetáculo: "Tudo evolui exceto o coração dos homens". 
Espere, não me pergunte ainda, eu estou procurando, eu estou experimentando, eu estou fazendo o meu melhor, mas o que eu faço hoje, ainda não representa o meu pensamento, e meu trabalho de hoje é dar à luz ao meu pensamento para amanhã.

COPEAU

\section{Introdução:}

O meu primeiro encontro com o Mimo Corpóreo aconteceu em 1999 na oficina com a companhia $\mathrm{AMOK}^{3}$ do Rio de Janeiro, dentro das atividades do Encontro Mundial das Artes Cênicas, ECUM, em Belo Horizonte - eu já trabalhava com a mímica de outras formas havia mais de seis anos - fui arrebatado pelo treinamento, encontrei algo que se encaixava em minhas expectativas sobre o fazer teatral focado na corporeidade. $\mathrm{Na}$ intensidade desse encontro nasceu meu primeiro espetáculo autoral, um solo chamado de "M.C.C.R.E. ${ }^{2}$ " (Movimentos Comuns e Cotidianos Repetidos ao Extremo e ao Quadrado), que estreou no Centro Cultural São Paulo - CCSP; em 2000, e depois, foi apresentado em alguns festivais durante o mesmo ano. No ano seguinte em busca por uma formação regular fui estudar em Londres, Inglaterra, na International School of Corporeal Mime. Completei o curso em três anos e aproveitei a estadia no estrangeiro para dar continuidade à busca de um teatro "mais corporal”, experimentei também outras práticas, tais como, máscaras, dança contemporânea.

No retorno ao Brasil em 2007, deparei com desconhecimento da maioria de profissionais da área sobre o que vinha ser o Mimo Corpóreo. Tive grandes dificuldades em conseguir espaço para apresentação de trabalhos cênicos sobre esta pesquisa, encontrei grande resistência por parte de algumas entidades culturais e curadorias de editais que insistiam em negar espetáculos corporais de dramaturgia não-linear como pertencente ao gênero teatral, a justificativa era a de que a encenação flutuava em uma espécie de limbo entre o teatro e a dança.

Percebendo a necessidade de divulgar e promover a arte do Mimo Corpóreo, organizei um projeto multidisciplinar chamado de Projeto Mímicas ${ }^{4}$, essa iniciativa contemplava 3. Companhia teatral sediada no Rio de Janeiro dirigida por Ana Teixeira: http://www.amokteatro.com.br/ 4. Veja mais informações nos anexos. 
palestras, intercâmbios, publicação impressa, oficinas e uma mostra anual de Mímica Contemporânea $^{5}$ (www.mímicas.com). Esse projeto durou cinco anos e foi um grande fomentador para vários artistas e pesquisadores da área, promovendo vários encontros entres estudantes e profissionais de vários estados brasileiros.

Durante o Projeto Mímicas, tive a oportunidade de conhecer e realizar treinamentos com Thomas Leabhart, Marize Flash e Yves Le-Breton, antigos assistentes de Etienne Decroux em várias fases de sua carreira pedagógica, esse contato ampliou minha visão de possibilidades desta técnica corporal, auxiliando na busca de apropriação metodológica e sua aplicação em processos de ensino/aprendizagem e criação.

Após esse período fértil, entrei em processo de reflexão sobre todo o material e as questões que surgiram durante os encontros e intercâmbios, repercutindo em meu trabalho artístico e pedagógico, revelando uma necessidade de estudo da aplicação da técnica em processos de ensino/aprendizagem e treinamento. Essa reflexão também fomentou a criação de uma trilogia de solos, chamada de Trilogia da Dúvida, em que o primeiro trabalho tem o seu processo explicado na página 87.

Durante a minha prática pedagógica consecutiva nesse processo de reflexão, fui confrontado com um "problema" que não pode ser resolvido apenas pela aplicação dos exercícios e/ou pela organização da pesquisa - a questão da relação da subjetividade dos exercícios plásticos -, prática realizada pela metodologia: observação-repetição, onde cada exercício demanda uma grande quantidade de repetições. Percebi que a relação entre o movimento e a sua subjetividade não era uma relação compulsória, isto é, a realização de exercícios que partem de formas/desenhos corporais preestabelecidos não despertam, necessariamente, a subjetividade ${ }^{6}$ de todos os participantes/alunos, podendo se transformar numa "ginástica estranha" para alguns; a contínua repetição de formas corporais simplesmente como um fim pode dispersar a concentração, gerando uma desassociação ${ }^{7}$ mental com o que se está fazendo.

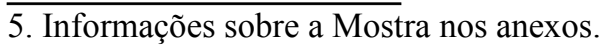

6. Chamamos de "subjetividade" o alinhamento do reflexo interno(mente) dentro das ações corporais pela relação corpo-mente.

7. Uso os termos 'associado e desassociado' para definir o estado de concentração na ação corporal, quando se está 'presente' na ação, mente e corpo na mesma ação; ou quando se está pensando em outra coisa alheia ao que se está se fazendo, repetindo os movimentos mecanicamente.
} 
Sem querer demonizar a questão da repetição dentro do treinamento, que é essencial e necessária, porém buscando uma execução dinâmica em que: "se repetindo uma prática de natureza técnica podemos pouco a pouco modificá-la, alterá-la ou melhorá-la. Para melhorar uma habilidade precisamos mudar as regras que são repetidas." (SENNETT, 2009, p. 203) Defendemos aqui uma forma de repetição "flexível", em que o estudo de sua subjetividade faça com que ela seja permeável à experiência dos praticantes, em função de uma prática para realizar o que chamaremos de movimentos orgânicos:

(...) é uma espécie de força que gera o próprio corpo subjétil ${ }^{8}$ e, portanto, gera o próprio estado de arte dentro do Estado Cênico... a organicidade gera um estado orgânico/inorgânico, natural/artificial coexistentes em um mesmo sistema. E como o Estado Cênico é composto por um sistema que relaciona dinamicamente vários elementos, a organicidade, como a vejo é justamente a força que aproxima e mantêm unidos esses vários elementos. Sendo definida como força, não pode ser um elemento concreto que possa ser pontuado ou quantificado. (FERRACINI, 2006, p. 126)

Portanto assumimos como organicidade algo relacional que:

(...) deve ser trabalhada, gerada e pressionada concretamente por entre todos os elementos constituintes do corpo-subjétil. A organicidade coloca o corposubjétil numa relação dinâmica com seus elementos constituintes e, ao mesmo tempo, são esses mesmos elementos constituintes em relação que geram a organicidade. (FERRACINI, 2006, p. 127).

A organicidade que buscamos, acontece por esta relação dinâmica entre corpo e mente "forma e subjetividade" em relação colaborativa como o proposto pelo paralelismo espinosano, descrito a seguir:

(...) o estudo do movimento só pode ser efetuado de maneira convincente se for acompanhado de uma reflexão sobre a interioridade do sujeito em movimento, chame-se ela emoção, imagem, mental ou vida interior. Ela obriga a incessante vaivém entre moção e emoção. As diversas teorias e treinamentos do ator consistem em elucidar este vaivém que pode tornar-se

8. Corpo subjétil se entende como um corpo que vive a deslocar-se criando a possibilidade de recriação das ações físicas, recriando seus fluxos de ações constantemente. (FERRACINI, 2006, p.10) 
busca da diferença (da dualidade) ou, ao contrário, da fusão, da organicidade entre corpo e espírito. (PAVIS, 1999, p. 253)

Durante a graduação em Filosofia pela Universidade São Judas Tadeu (USJT), 2008-2010, apresentei pesquisa de iniciação científica pelo Programa Institucional Voluntário de Iniciação Científica (PIVIC) e o Trabalho de Conclusão de Curso, TCC, dentro da problemática "Corpo e Mente" na obra A Ética de Espinosa - foi algo natural trazer o conceito de paralelismo 9 como agente provocador como base do estudo da relação "Corpo/Mente" dentro deste trabalho - entendo que para falar sobre a questão da organicidade é necessário discutir antes a relação "Corpo/Mente". Luís Otávio Burnier confirma a importância disso em sua obra A arte de ator, em que afirma o treinamento de uma técnica corporal não poder "[...] negligenciar o contato corpo-pessoa" ${ }^{10}$, reafirmando a importância dessa questão.

Espinosa foi contra a tradição dualista propondo em sua doutrina filosófica uma união substancial entre "Corpo/Mente" em que os dois são a mesma substância se manifestando em modos $^{11}$ distintos e agindo juntos pelo paralelismo. Levamos essa indicação para o processo de treinamento: mente (subjetividade) e corpo (forma) trabalhando juntos sem apresentar relação hierárquica, investigando os desdobramentos positivos que isso pode trazer a práticas de ensino e a aplicação em processos de criação.

(...) $\mathrm{O}$ conflito [no trabalho de Decroux] não é apenas entre o homem e o resto do mundo, mas também internalizado para que o homem esteja em conflito consigo mesmo, porque a sensação de peso agindo de determinada maneira sobre o corpo está em desacordo com a força de vontade que age sobre este mesmo corpo de outra maneira. A Mímica Decrouxiana é de certa forma uma dramatização radical da distinção cartesiana entre mente e corpo. (NYE, 2011, p. 93)

Etienne Decroux por outro lado parecia criar em seu trabalho sobre o conflito dualista “Corpo/Mente", "a mente do artista mímico não está em harmonia com o corpo; ele não

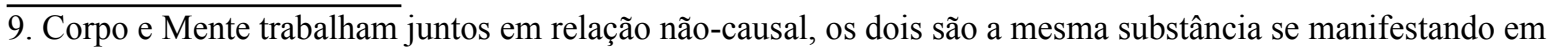
modos diferentes e temporários.

10. (BURNIER, 2002, p.53)

11. Modo ou afecção da substância, que é na substância e por ela se concebe (E I, def. 5). Donde uma consequência que já podemos adiantar: toda coisa singular é modo, e as determinações subsequentes que lhe advêm devem ser, a cada caso, referidas a seu estatuto modal. Por outro lado, nem todo modo é coisa "singular", pois Espinosa conceberá modos infinitos imediatos e mediatos; (ESPINOSA, 2009) 
coloca a mente sobre o corpo, em vez disso, a sua mente permanece independente, inteiramente racional." (NYE, 2011, p. 86), com o ideal de tornar "visível o invisível”"12, o corpo se torna à representação do processo interno do pensamento pela dilatação de sua presença física em cena, "O mímico faz a ação e o espectador, ao ver a ação materializada pensa em sua analogia com o espiritual (...) Nós mímicos, devemos procurar fazer poesia através das ações, não das palavras” (DECROUX, 2003, p. 105). Esta questão também será discutida a diante, em que propomos uma análise desses termos com a ajuda da neurociência partindo de escritos do neurocientista francês, Alain Berthoz.

Antes de escolher quais exercícios da prática seriam os objetos de estudos, entendemos necessário organizar e documentar a abordagem do "Mimo Corpóreo", dividindo a parte técnica em categorias e suas aplicações, diferenciando as partes dos elementos da prática.

Por isso dedicamos um capítulo a escrita de uma breve proposta pessoal de organização e documentação dos termos da parte técnica, experimentando organizar as diferentes categorias, objetivos expressivos e os procedimentos de aplicação, para tornar acessível aos leitores que desconhecem a técnica uma melhor compreensão de sua complexidade e profundidade.

É importante clarificar o significado que daremos a alguns termos utilizados aqui, são eles:

- Biomecânica: como o estudo do movimento pelas articulações e interações do corpo com o meio, não se referindo ao trabalho do diretor russo Meyerhold, mas a seu conceito principal que é o estudo das: "características do movimento do ser humano ou um objeto que são descritos usando parâmetros como velocidade e direção; como o movimento é criado através da aplicação de forças, tanto dentro como fora do corpo." (HAMIL, 2015, p. 05)

- Técnica e Método: definimos como técnica o conjunto de procedimentos, categorias e práticas de um estudo fechado, e método a "forma" de sua aplicação pessoal de cada praticante, "o método pode ser uma maneira de aplicar uma única técnica ou diferentes fragmentos de técnicas distintas para seu fim" (SEIXAS, 2009, p. 51).

12. “é preciso tornar visível o invisível” e não o contrário. (DECROUX, 1994, p. 200) 
- Segunda e terceira geração: utilizamos no texto a terminologia, "segunda geração" aqueles que estudaram com o próprio Decroux, e "terceira geração" - aqueles que estudaram com os que estudaram com o Decroux.

- Mimo Corpóreo: chamamos de Mimo Corpóreo a nossa abordagem da técnica e as abordagens contemporâneas, utilizando a grafia proposta pelo diretor/pesquisador Luís Otávio Burnier, e usaremos a grafia, "Mímica Corporal” ou "Mímica Corporal Dramática" ou às vezes apenas "Mímica" para se referir ao trabalho do próprio Decroux.

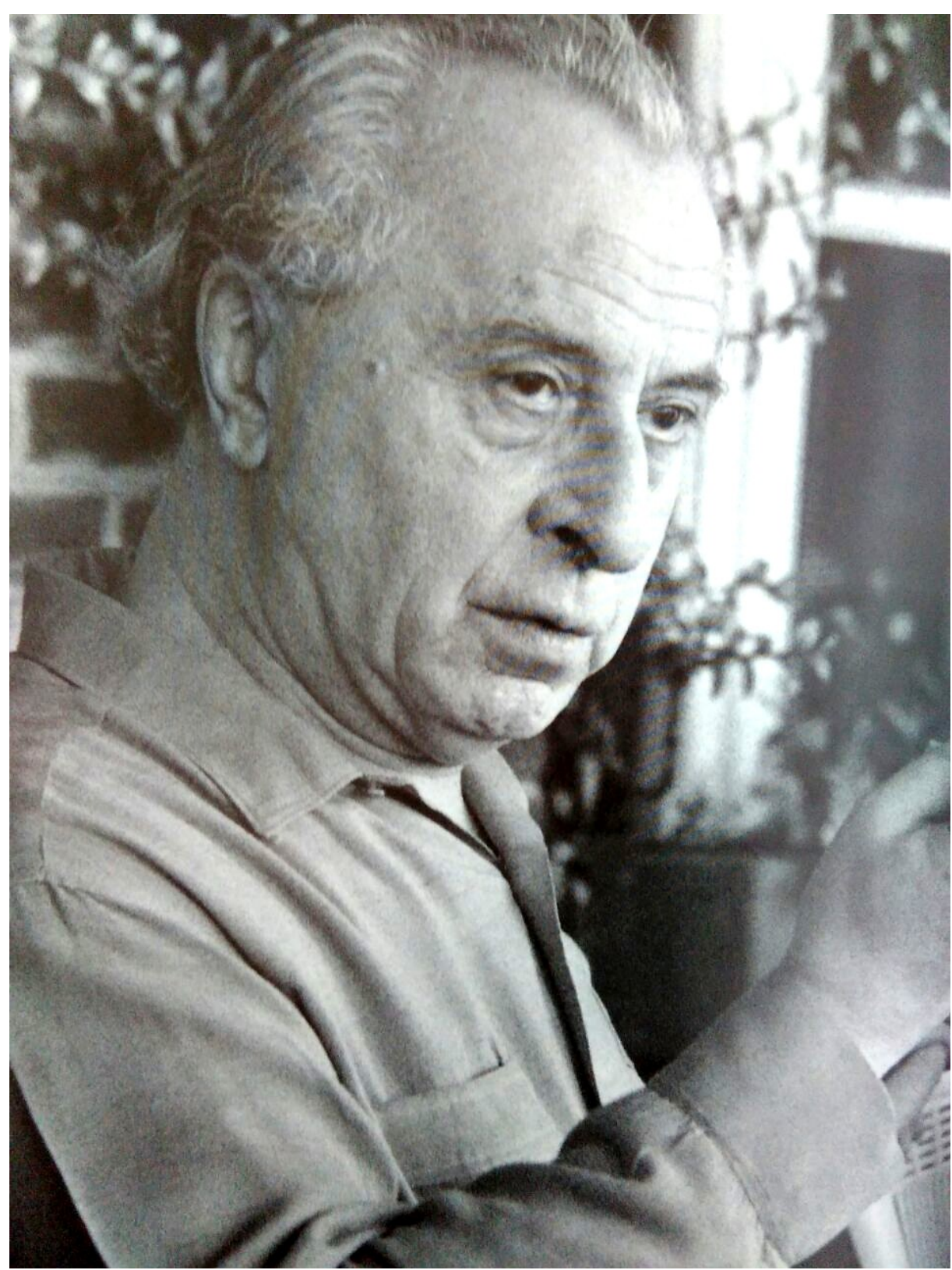

Figura 1- Etienne Decroux (LEABHART, 2001, p. 8). 


\section{CAPÍTULO I}

\subsection{A Redescoberta do Corpo no século XX}

$\mathrm{O}$ início do século XX foi marcado por enormes mudanças sociais, científicas e culturais, uma das mais importantes foi a redescoberta do corpo, mudando o paradigma de tradição platônica de eximir o corpo como parte da identidade do indivíduo, o que influenciou a forma do homem se relacionar entre si e o mundo. Essa visão de identidade trouxe grandes transformações nas formas de se expressar por meio da literatura, teatro e artes em geral, "o corpo, em particular, é colocado no centro de inumeráveis reflexões, concepções e experimentações que envolvem diferentes âmbitos: científico, filosófico, pedagógico e artístico" (ROPA, 2011, p. 117).

Isto é um processo que achou um dos seus pontos mais fortes no Körperkultur que pregava a redescoberta do corpo e seu enorme potencial expressivo, deixado praticamento inexplorado pela tradição teatral, literária e psicológica que preferia uma dimensão de atuação puramente verbal e declamatória. (MARINIS, 2015, p. 114)

Sobre influencia de movimentos como o Körperkultur ${ }^{13}$ "Cultura do Corpo" que começou no final do século XIX na Alemanha abriu-se espaço para a afirmação da presença do corpo como possibilidade estética e identidade, isso modificou também as relações hierárquicas dentro da produção artística, no caso do teatro em que o ator estava subjugado a dramaturgia escrita, agindo como um "pronunciador de palavras", o pensar no corpo em cena levou imediatamente a pensar sobre a importância da presença do ator em cena, reorganizando as prioridades do trabalho e colocando o gesto e a presença física do ator no mesmo patamar que a palavra, isto pedia uma nova postura ética do ator em relação à cena e também um repensar sobre a sua formação.

Essa atenção ao corpo do ator em cena, segundo o professor Marco de Marinis, não acenava para uma inversão de prioridades com o abandono de importância da palavra em detrimento ao gesto, mas o reconhecimento de importância do corpo, "deve haver pouca dúvida de que o fenômeno da chamada:

13. Körperkultur - Cultura do Corpo - corrente estética que levou a uma revolução na mentalidade da época pelo gosto e uso da higiene. Foi uma corrente histórica que partiu de Schopenhauer (1788-1860), envolveu Nietzsche (1844-1900) e Wagner (1813-1883) e encontrou ressonância no campo teatral (BONFITTO, 2013, p. 10). 
(...) "redescoberta do corpo" no teatro europeu no início do século XX foi fortemente influenciado pela dupla ideia de primazia e da natureza originária da linguagem física, por um lado, e por outro lado, da energia expressiva e comunicativa pertencente ao gesto em vez da palavra. (MARINIS, 2015, p. 192).

"Esse processo dá ao corpo a mesma dignidade que já havia na ideia de intelecto e espírito, através do ideal de trindade na concepção do homem” (BONFITO 2013. p. 10), o corpo passa a ser agente direto dentro da concepção da identidade. Essa mudança de pensar provoca a construção de uma nova identidade corporal e, a partir daí, novas buscas nas artes, em que o corpo possa ter espaço como agente direto na criação e na expressão.

Foram diversas manifestações artísticas que colocaram o corpo em destaque, a dança livre e expressiva de Isadora Duncan, corpo energético de Rudolf Laban, a euritmia de Jacques Dalcroze, a Biomecânica e a própria Mímica Corporal entre outras.

A Mímica Corporal, que nasceu desse movimento de redescoberta do corpo, germinou dentro de um dos mais importantes movimentos de renovação do teatro dessa época, foi uma iniciativa que não apenas mudou o espaço físico do teatro, subindo os refletores para o teto do teatro, retirando o fosso, aproximando o palco da plateia, como também mudou o ator que atuou e criou nesse novo teatro. A formação desse novo ator partia do corpo e sua expressão, tanto na formação como na criação.

A Ecole du Vieux Colombier de Copeau, oferecia uma extraordinária educação teatral comparada com os ultrapassados treinamentos para atores dos conservatórios de sua época. Copeau foi o pai de uma educação liberal e completa para o ator em contrapartida ao treinamento restritivo de formação profissionalizante de teatro típica do teatro convencional de sua época, que ele rejeitava completamente.

(LEABHART, 1989, p. 26).

Esse foi o teatro-escola Vieux-Colombier, fundado em 1913 e suspendendo as atividades por causa da I Guerra Mundial no ano seguinte, retornando apenas em $1921 \mathrm{em}$ que durante três anos abrigou a companhia e a escola do visionário:

\subsection{Jacques Copeau (1879-1949)}

Jacques Copeau nasceu em 1879 na cidade de Paris. Foi diretor, crítico e professor de Arte Dramática. Começou sua carreira no teatro aos 32 anos de idade após trabalhar oito anos 
como crítico de teatro e ter dirigido sua própria adaptação de Os Irmãos Karamazov, de Dostoievski; mas, dois anos depois, finalmente abandonaria sua promissora carreira literária para uma carreira questionadora no teatro.

Movido por uma insatisfação com o teatro de sua época e pelo desejo de realizar uma reforma e revitalização da arte da encenação, em 1913 em uma empreitada apaixonada com a ajuda de amigos da revista que foi um dos fundadores e o primeiro editor, a Nouvelle Revue Française $^{14}$, abre numa das margens do rio Sena, o Théâtre du Vieux Colombier, em um prédio que havia sido anteriormente um teatro de variedades, despojando-se do antigo teatro, "das suas tapeçarias de mau gosto e enfeites de gesso dourada e, eventualmente, até mesmo o seu arco do proscênio." (RUDLIN, in HODGE, 2010, p. 43).

Esta mudança da arquitetura em seu novo teatro, era apenas o reflexo das mudanças que Copeau queria realizar no fazer teatral, empreitada que mudou significativamente toda a produção teatral e a ideia de preparação de atores ao longo do século XX.

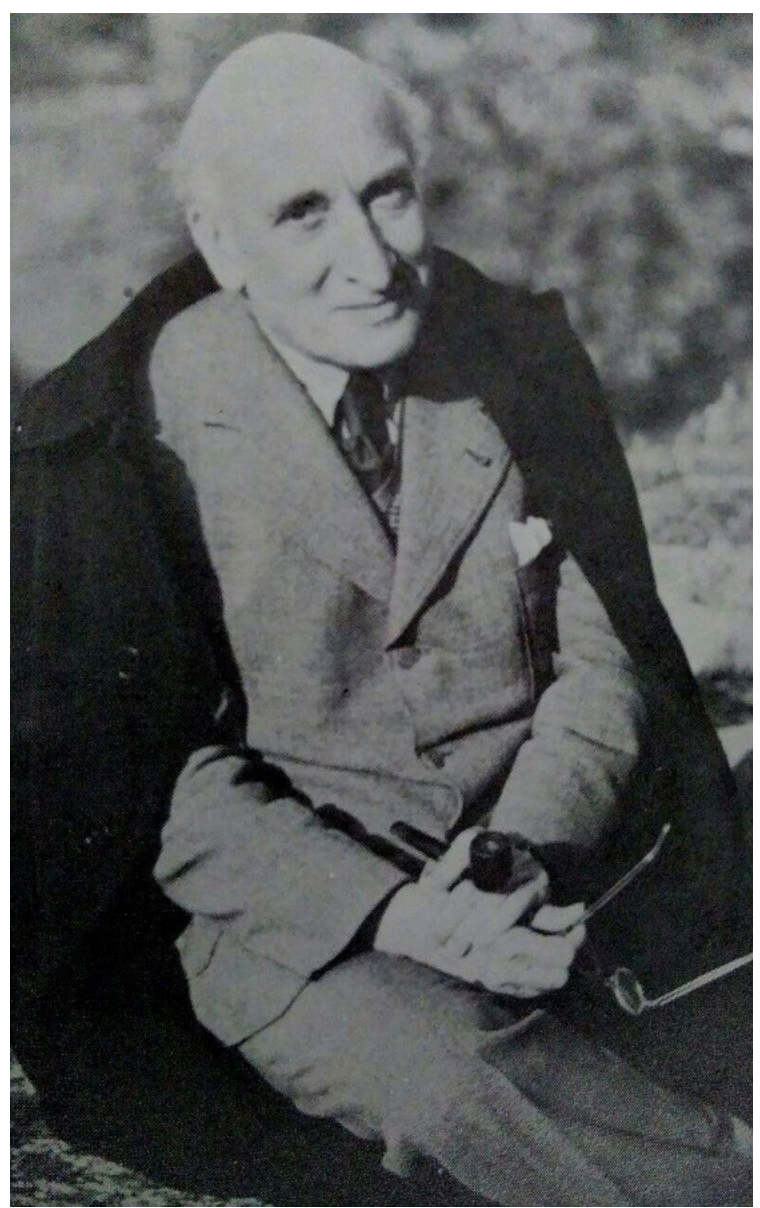

Figura 2 - Jacques Copeau. Fonte (DORCY, 1961, p. 37)

14. Nouvelle Revue Française é uma revista literária fundada em 1909 por um grupo de intelectuais, incluindo André Gide, Jacques Copeau, e Jean Schlumberger. Em 1911, Gaston Gallimard tornou-se editor do Revue, o que levou à fundação da editora, Gallimard. 
A escola Vieux-Colombier começou a funcionar propriamente em dezembro de 1921, com a direção do dramaturgo e escritor Jules Romains e Suzanne Bing, atriz principal da companhia, como professora e assistente do próprio Copeau que somente em 1922 assumiria a direção de sua escola. O treinamento oferecido pela escola era algo inédito para o teatro ocidental, colocava o corpo do ator, sua presença e habilidades em evidência, passava da dança a acrobacia a habilidades artesanais, como desenho e modelagem, além de treinamento de voz, canto, exercícios de expressão dramática (máscara, jogos físicos, mímica) e improvisação (corpo e voz), além de aulas de locução, dicção e declamação e teoria e história do teatro.

A concepção de educação liberal para atores de Copeau incluía além dos cursos citados acima (ginástica olímpica, mímica e dança), aulas de balé clássico, a anatomia da voz, dicção comum, declamação de coro clássico e do Nô japonês, canto e escultura; história da música, figurinos, filosofia, literatura, poesia e teatro e mímica corporal. (LEABHART, 1989. p. 26)

O Método de Criação Cênica empregado na escola de Copeau, diferente do comum em sua época na França, não partia do texto para a cena, mas chegava a ele através do seu treinamento corporal, buscando "enobrecer" o uso da palavra tornando-a resultado do pensamento do ator "em todo o seu ser", tinham como um dos recursos para chegar a esse "estado" o treinamento com máscaras na formação de seus atores, iniciando com a máscara neutra até chegar a dramatizações em grupo.

Durante os três primeiros anos da escola os alunos praticavam além de outras diversas técnicas, o "mimo abstrato", pantomima, composição rítmica, voz, sempre relacionado com a improvisação a partir de roteiros simples e curtos que se tornavam mais complexos e extensos durante a prática.

Com a máscara, sentimos subitamente uma força e uma segurança totalmente desconhecidas. Tendo o rosto oculto, recobra-se confiança e ousase o que nunca se ousaria com o rosto descoberto. A máscara impõe uma grande força e amplitude em cada movimento, exigem movimentos completos e desenvolvidos até o fim, que tenham o mesmo caráter ponderado, regrado e forte, o mesmo estilo que a própria máscara. A máscara dá uma grande estabilidade e um sentimento forte de medida — e também 
uma espécie de consciência de si mesmo e do controle sobre si mesmo. Cada movimento se faz em relação à máscara. (COPEAU, 1974, p. 32).

Colocando o foco no corpo do ator como início de todo processo de treinamento e formação, abriram-se infinitas possibilidades e espaço para a entrada de novas metodologias e técnicas, algumas vindas por influência do teatro oriental e outros de artistas e pensadores contemporâneos de Copeau como Apia, Craig, Dalcrose ${ }^{15}$, entre outros.

Muitas coisas podem ser ditas sobre a escola do Copeau e suas buscas na renovação do teatro de sua época; seu pioneirismo influenciou toda uma geração, encontrando ecos de sua pesquisa até os dias de hoje; mas dentre os elementos utilizados pelo Vieux-Colombier o que vamos observar com mais cuidado é a máscara, neste estudo o véu utilizado como ferramenta principal nessa busca por "um estado de neutralidade" do ator, exercício chamado de "Mímica Corporal" ou "a máscara" pelos alunos; essa parte do treinamento proposto por Copeau fascinaria profundamente um aluno recém-chegado à sua escola:

\subsection{Etienne Decroux}

\subsubsection{O artista}

Etienne Decroux (1898-1991), um dos grandes criadores do teatro no século XX, deixou um legado inquestionável para o teatro contemporâneo, uma técnica corporal completa, composta de parte prática e conceitual, aplicável tanto para o treinamento do ator como para a criação cênica, sendo comparada por Eugênio Barba como a única escola do teatro ocidental a se assemelhar as formas de ensino no teatro asiático ${ }^{16}$.

O trabalho de Etienne Decroux está profundamente enraizado na renovação teatral francesa que ocorreu entre os anos de 1910 e 1920, que começou a partir do manifesto de Jacques Copeau para a renovação do teatro publicado no La Nouvelle Revue Française em 1913, e a subsequente criação do Le Théâtre du Vieux-Colombier. Esse processo continuou e foi ampliado depois pelos Animateurs do Cartel des Quatre, Charles Dullin, Louis Jouvet, Georges Pitoëff e Gaston Baty, assim como várias outras pessoas que trabalharam e estudaram

15. Émile Jaques-Dalcroze (1865-1950), Copeau chegou a usar a metodologia de Dalcroze com seus atores, mas mudou de ideia por achar esse treino mais ligado a música, preferindo usar no treinamento as ideias da "Cultura Física” do desportista e educador físico francês Georges Hébert (MARINIS, 2015. P.52)

16. “...Talvez o único mestre europeu que elaborou um sistema de regras comparável às de uma tradição oriental.” (BARBA, 1995, p. 8) 
com Copeau, especialmente aqueles que, em 1931, formaram a Compagnie des Quinze, sob a direção de Michel Saint-Denis.

Decroux estudou durante um breve período na L'École du Vieux-Colombier em 1920, atuou na companhia de Baty e Jouvet, e até 1934, foi membro da companhia de Dullin no Théâtre de l'Atelier, período que deu início a sua pesquisa, junto com Jean-Louis Barrault.

O desejo de seguir o seu próprio caminho nasceu após o período em que Decroux frequentava a Vieux-Colombier, arrebatado pela beleza de corpos em movimento dentro de um dos treinamentos da escola chamado de "Mímica Corporal", em que os atores improvisavam com máscaras neutras, véus e o "mínimo de roupas que a decência permitia" esta prática o impressionou de tal forma que além de despertar seu interesse pelo trabalho corporal deu a guia para uma pesquisa que durou toda sua vida, e foi o nome que ele deu ao seu trabalho, “(...) Copeau foi o pai, eu apenas criei o seu filho...” (DECROUX, 1994. p. 54)

A carreira de Decroux navegou entre um apaixonado criador, persistente pesquisador e inquieto pedagogo, mas independente de seu momento, ele precisava de atores para levar adiante o seu grande projeto, "ele queria que eles continuassem trabalhando em sua catedral da Mímica Corporal", um projeto que precisava de trabalhadores em gerações por vir" (LEABHART, 2007, p. 37).

Decroux precisava comprovar a validade de seu trabalho formando novas gerações que fossem capazes de corporificar suas ideias, dando continuidade a construção de sua "catedral". Talvez, por isso, ele seja mais lembrado como pedagogo do que como diretor/criador, mesmo tendo criado uma série de peças e figuras coreográficas. Sua preocupação com o ensino cresceu gradualmente, se transformando em foco principal nos últimos anos de sua carreira quando abriu sua própria escola no porão de sua casa em que ensinou até o final de sua vida.

17. "Chamávamos isso de máscara. O contrário das máscaras chinesas, a nossa era inexpressiva. O corpo ficava tão nu quanto à decência o permitia. Medida indispensável. Porque, anulado o rosto, todos os membros do corpo não eram suficientes para substituí-lo. Mimávamos ações modestas: um homem importunado por uma mosca quer ver-se livre dela; decepcionada com a cartomante, uma mulher a estrangula; um ofício, um encadeamento de movimentos de máquina. O jogo tendia para a lentidão da câmara lenta do cinema. Mas enquanto a câmara lenta do cinema é uma desaceleração dos fragmentos do real, a nossa desaceleração era a produção lenta de um gesto no qual muitos outros eram sintetizados. Esse jogo já legível era belo. (DECROUX, 1994, p.21, tradução nossa) 


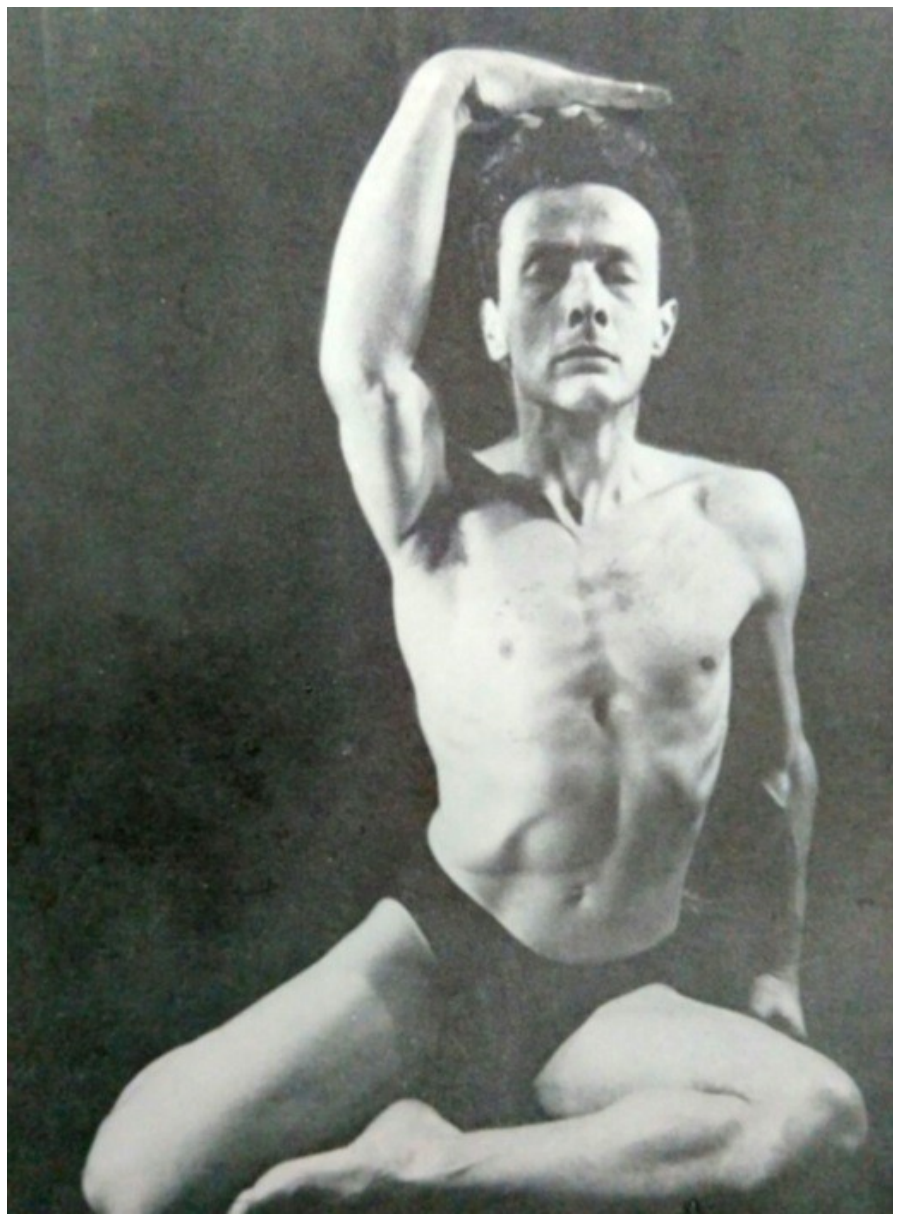

Figura 3 - Jean-Louis Barrault: La Mort. (DORCY, 1961, p. 51)

\subsubsection{O pedagogo}

A pesquisa de Decroux começou a ganhar formato a partir de 1926 quando ele ingressou na companhia de Dullin ${ }^{18}$, após o fechamento do teatro de Copeau e sua curta tentativa frustrada de criar uma comunidade artística ${ }^{19}$. Dullin abriu espaço para Decroux desenvolver a sua prática paralelamente com as atividades da Cia. apresentando sua primeira composição de mímica em 1931, La Vie Primitive, ano que também publicou o seu primeiro texto teórico, esse duo com a sua esposa Suzanne Lodieu, trabalho duo com a sua esposa, logo se transformou em trio com Jean-Louis Barraut que acabava de entrar na companhia de Dullin

18. Charles Dullin (1885-1949) ator, diretor e pesquisador teatral. Formou sua própria companhia em 1921 com o nome de Atelier, onde deu continuidade as lições recebidas com Copeau, abrindo espaço em seu teatro para que Etienne Decroux realizasse sua pesquisa de forma autônoma de sua companhia.

19. Copeau, fechou a sua escola-teatro em Maio de 1924 por problemas financeiros e administrativos, mudando sua companhia para o castelo de Morteuil em Borgonha no sul da França. Com a intenção de realizar uma comunidade teatral, essa experiência de Copeau não deu certo por problemas financeiros; encerrando o projeto em Fevereiro de 1925. Alguns dos colaboradores deram continuidade sem Copeau chamando essa nova iniciativa de "Les Copiaus" (VER MARINIS, 2015. P.213). 
e logo fora "recrutado" por Decroux para a sua pesquisa por apresentar um grande talento para o movimento corporal, Barraut foi o primeiro e talvez mais importante parceiro e colaborador de Decroux, a pareceria dos dois foi breve, mas profícua,

Depois de dois anos de intensa colaboração preparando as fundações para a mímica moderna, eles apresentaram o Ancient Combat (Combate Antigo) para Dullin que reconheceu que este trabalho tinha atingido a perfeição técnica dos atores japoneses. O Atelier de Dullin que abraçava o teatro como um laboratório era um dos poucos espaços em Paris onde experimentações como essa poderiam acontecer. (LEABHART, 2007, p. 10)

Esse período de colaboração com Dullin foi onde Decroux teve a oportunidade e estrutura de começar a ganhar autonomia em sua pesquisa, seu núcleo de estudos dentro do espaço físico da escola tinha total liberdade para experimentar e apresentar publicamente suas criações de mímica, além de encontrar participantes dedicados para suas práticas entre os alunos e os integrantes da companhia.

Durante os vinte anos que Decroux esteve junto com o Atelier, ele trabalhou na companhia como ator, foi assistente de direção do próprio Dullin, proveu treinamento corporal para os atores e ministrou aulas de Mímica Corporal na escola anexa do teatro, se o impulso de Decroux nasceu na Vieux-Colombier, foi no Atelier de Dullin que ganhou forma e objetivo.

Não é sabido se Dullin detinha o interesse em especial pelo uso de máscaras ou véu sobre o rosto para o treinamento de atores, não encontramos nenhuma referência de seu uso em seus textos e artigos escritos sobre a época ou de participantes desse período, levando a acreditar que essa prática não fazia parte da rotina de treinamento, também não encontramos nenhuma referência sobre Decroux ter dado continuidade a usar este recurso durante a sua estadia no Atelier.

Além de partir do corpo como base do treinamento e da criação, influência da escola de Copeau no Atelier de Dullin pode-se destacar outros elementos que foram determinantes tanto no seu trabalho como no de Decroux, a necessidade de construção de um corpo não cotidiano, o gosto pela estilização e metáfora com a influência do teatro oriental, a mímica e o improviso como ferramenta de criação, "para se gerar um bom ator é necessário tirar a rede de proteção da tradição, modelos copiados de atuação e a segurança do texto para se apoiar" (MARINIS, 2015, p. 76). 
A Colaboração de Dullin na construção da Mímica Corporal é inegável, além do espaço físico e suporte para o desenvolvimento de sua pesquisa, Decroux comenta sobre o período que esteve com Dullin como fator determinante para o refinamento de seu gosto artístico, "Dullin me recebeu em uma forma completamente rudimentar, ele me instruiu, me formou. (...) Ele tentou me passar o que é chamado de bom gosto...” (DECROUX, 1978, p. 14).

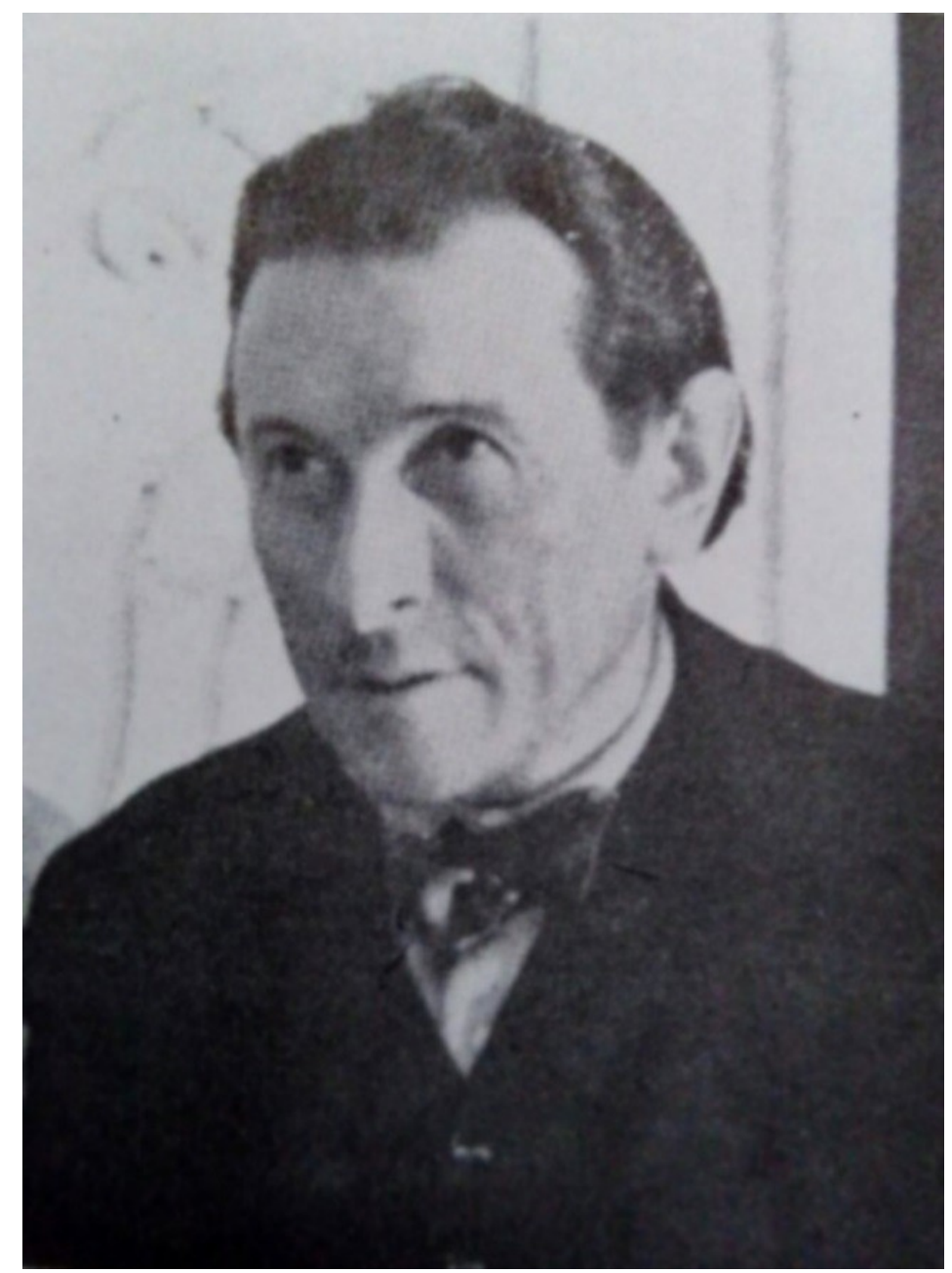

Figura 4 - Charles Dullin Fonte: DORCY, 1961. p. 51

Decroux saiu da companhia de Dullin em 1947 para se dedicar à formação de sua própria companhia e escola, realizando nos anos seguintes diversas viagens para divulgar a sua "nova arte", este mesmo ano a sua nova pequena companhia realizou uma tournée pela Europa, Bélgica, Suíça, Holanda, Israel e Inglaterra, se apresentando ocasionalmente também em Paris nos anos seguintes; esse período foi frutífero para a carreira de Decroux atraindo 
alunos de todas as partes da Europa e da América, além de ser convidado para dar palestras e cursos em diversos países.

A partir de 1953, Decroux passa longos períodos ensinando fora de Paris deixando a sua escola sob o comando de seu filho Maximilien Decroux; 7 meses na Itália no Piccolo Teatro di Milano, 2 meses em Oslo, 3 em Estocolmo e um longo período no EUA de 5 anos em 3 idas e voltas, onde ele ministrou palestras-demonstrações em 10 diferentes universidades, no Actor's Studio e em outros diversos espaços, lecionou na Universidade de Nova Iorque, fundando na cidade uma nova companhia com elenco norte-americano realizando várias apresentações, recebendo uma resposta entusiástica da crítica.

Essa longa temporada nos Estados Unidos se encerrou em 1963, quando ele retornou para França, abrindo um pequeno estúdio no porão de sua casa no bairro BoulogneBillancourt, periferia de Paris, casa construída pelas mãos de seu próprio pai.

Após o retorno dos EUA Decroux se debruçou um pouco mais em sua pesquisa pedagógica, mas sem nunca abandonar a criação de novas peças e figuras e a realizar apresentações públicas, apenas em menor escala de público e de entusiasmo. Se reservando a poucas aparições fora de sua escola e sem manter uma companhia fixa, realizava as suas demonstrações sozinho ou acompanhado de poucos alunos mais assíduos que conseguiam lidar com o intempestivo gênio de seu professor.

\footnotetext{
Decroux começou pela prática teatral e o impulso que o levou a se dedicar exclusivamente a uma prática corporal foi o desejo de corrigir as intoleráveis deficiências fundamentais que ele encontrava no teatro e nos atores de sua época. Por consequência Decroux não queria abandonar o teatro, mas se dedicar integralmente a sua transformação radical com o objetivo de o prenúncio de um "outro teatro" através da proposta de um "teatro que é um outro" (ou seja, é um "outro gênero": mímica corporal). (MARINIS, 2015. p. 188, tradução nossa)
}

Essa preocupação de Decroux em manter o ensino constante, vem da tradição do Vieux-Colombier, que para formar um novo-teatro precisava primeiro de novos-atores, criando a necessidade de se ter uma escola permanente para formar essa nova geração que viria realizar essa mudança, "a escola subterrânea de Decroux, onde ele formava atores para seu novo teatro, o requeria tempo num único lugar, trabalhando em si mesmo e nos seus estudantes." (LEABHART, 2007. P19) 
A escola no porão manteve uma rotina de aulas em dois turnos e de palestras regulares e demonstrações às sextas-feiras a noite, para os próprios alunos e alguns poucos convidados que queriam conhecer seu trabalho e/ou ingressar na escola, essa última fase de Decroux durou 24 anos, de 1963 até o fechamento da escola em 1987, já com 89 anos de idade e a saúde seriamente abalada. Falecendo em 1991, 4 anos após o fechamento da sua escola.

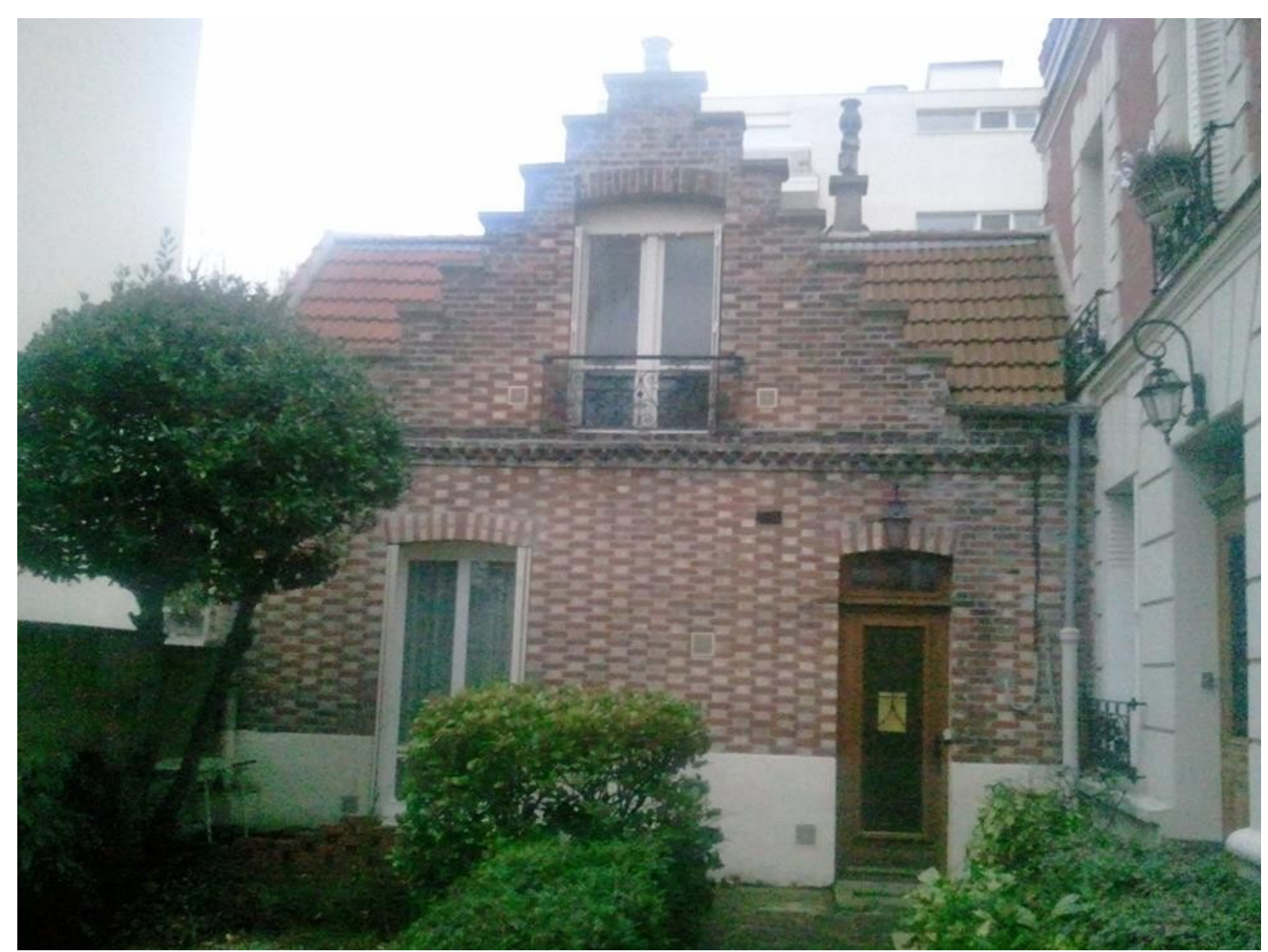

Figura 5- Casa/estúdio de Decroux em Boulogne-Billancourt (Paris). Fonte: Acervo do autor (Foto tirada em Dezembro de 2011)

Seguindo a tradição do Vieux-Colombier, Decroux esteve sempre em constante pesquisa, apresentando poucas mudanças de interesse e algumas fases distintas durante os seus 60 anos de carreira. Devido a pouca produção escrita, apenas um livro, Paroles sur le Mime, de linguagem mais poética que técnica, essas mudanças são observadas pelos relatos de ex-alunos, cada um apresentando uma versão levemente distinta da técnica, conforme o período que estiveram com o falecido "mestre".

Durante um curto período, no início da sua pesquisa, ouve um interesse em estudar a "imitação do real", prática logo abandonada para dar lugar ao estudo da "mímeses do real", algo que se tornou a base da construção dos exercícios e das práticas. Por não existir indicações das suas "mudanças de cursos" de forma escrita, e sim apenas pelos relatos de 
diferentes profissionais, temos de ser cautelosos ao falar de Decroux no singular (MARINIS, 2015, p. 6), Marco de Marinis caracteriza três fases importantes de Decroux:

Fase 1: Decroux como o inventor da Mímica Corporal, um novo gênero teatral(gênero fortemente codificado).

Fase 2: Decroux como pesquisador de uma forma de arte pura (e essencial), baseado no uso da expressividade estética do corpo, pelo estudo das atitudes/gestos/movimentos, mas ainda sem um conjunto rígido de codificação e divisão entre gêneros.

Fase 3: a sua fase mais importante, Decroux que durante mais de 60 anos de pesquisa/trabalho/ensino, "desenvolveu a mais rigorosa, profunda e sistemática investigação da arte de ator" (MARINIS, 2015, p. 8), algo que foi ganhando maior uniformidade e organização nos últimos anos de ensino, em que a técnica foi dividida em algumas categorias, cada qual com um vasto repertório de exercícios e práticas que será apresentada de forma resumida no capítulo III.

A proposta de execução e organização que está documentada a seguir é de certa maneira compartilhada pelos principais alunos da segunda geração ${ }^{20}$ que deram continuidade ao seu legado, sendo organizada pela experiência pessoal do pesquisador junto com entrevistas e aulas realizadas com os principais professores da segunda geração, além da consulta de artigos e livros sobre o assunto.

Infelizmente não há obras publicadas com explicações extensas e completas sobre a técnica, até o momento encontramos apenas estudos de algumas partes sem abrangê-la em toda a sua complexidade, a transmissão da Mímica Corporal ainda é exclusivamente de forma oral, algo que limita a divulgação desse conhecimento para apenas aqueles que procuram esses poucos profissionais que se dedicam a continuar este legado.

\subsubsection{A mímica corporal de Decroux}

Um dos objetivos de Decroux era fazer de sua Mímica Corporal uma disciplina artística autônoma independente da pantomima, dança e teatro falado, ele queria liberar do ator todos os artifícios que ele considerava acessórios, a palavra, música, etc., limitando a atuação ao movimento do corpo, o corpo em cena para chegar o que ele acreditava ser a

20. Para a organização dessa proposta aqui apresentada foram consultadas três diferentes escolas da segunda geração, International School of Corporeal Mime, Thomas Leabhart e Yves Lebreton. 
essência da atuação, "o teatro é de fato um acidente da mímica" (DECROUX em LEABHART, 2007, p. 15). Que é a mímica, e, portanto, o corpo que está no centro e na origem.

Decroux escolheu como símbolo de sua Mímica Corporal o cavalo-marinho, que sem braços e pernas se movimenta por meio de movimentos de sua coluna, essa metáfora correspondia à supremacia do tronco e sua articulação proposta por Decroux ${ }^{21}$, tanto no treinamento de sua técnica como na sua criação artística, onde braços e pernas são acessórios originados no próprio tronco (BARBA, 1995, p. 14). Com uma grande influência no ideal do estatuário, principalmente nas esculturas de Rodin, algo que o fascinava, colocar o tronco no centro da expressão, além de se afastar da ideia comum da mímica que priorizava os gestos com as mãos e caretas com a face na construção de narrativas, buscava no aumento de dificuldade na movimentação uma maior expressividade do corpo, "é preciso um treinamento técnico que fará o ator responder com o tronco com a mesma facilidade que a pantomima do século XIX (ou o gesto ordinário do dia a dia) fez com os braços e a face” (LEABHART, 2007, p. 63).

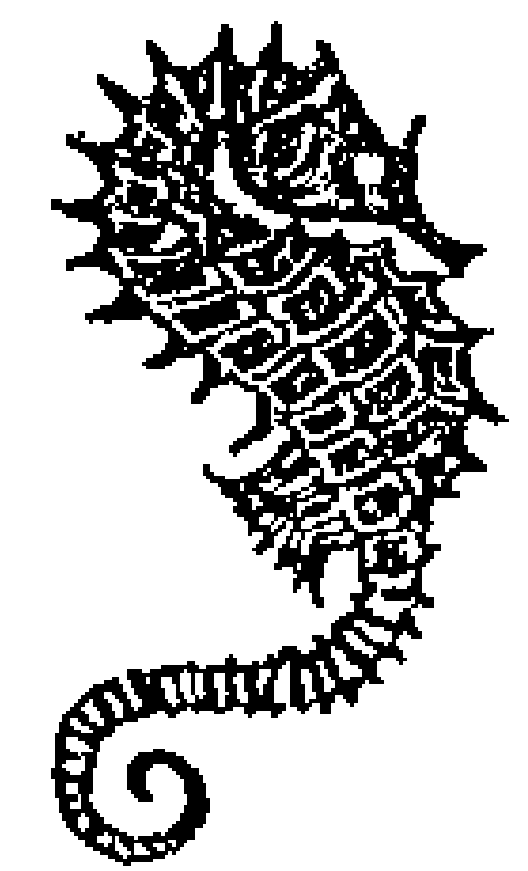

Figura 6 - Cavalo marinho desenhado por Decroux -

Fonte: (LEABHART, 2000, p. 37.)

21. Dentre o repertório de criações de Decroux, existe uma figura criada para treinamento dos braços chamada de l'hippocampe (cavalo-marinho) indicando que talvez Decroux teria abandonado esse ideal após algum tempo. 
Partindo da observação e da mimésis do corpo em ações físicas, Decroux tinha preferência pessoal pela expressão por abstrações e criação por signos, distanciando-se do movimento mimético relacionado à ação real (ilusão) que no início de sua pesquisa chegou até a ser seu objeto de estudos por um curto tempo.

Esse caminho por uma criação mais abstrata levou a muitas discussões sobre a proximidade do trabalho de Decroux a dança, questionado sobre o caráter "dançado" de sua mímica corporal, ele argumentava longamente sobre as distinções que existiam entre essas duas formas, associando o seu trabalho ao esforço, a luta constante contra a gravidade e a dança a leveza e a constante sublimação da gravidade, e mesmo com a sua insistência em separar as duas artes, alguns autores apontam o trabalho de Decroux como um dos precursores da dança moderna na França." (OLIVEIRA, 2011, p. 61)

Segundo alguns pesquisadores ${ }^{22}$, Decroux durante em certo momento de sua carreira chegou a lamentar a escolha do termo "Mímica Corporal" na definição de seu trabalho, "pois a mímica evoca a pantomima, ao passo que o jogo corporal é muito mais amplo nas suas implicações" ${ }^{23}$, e provavelmente essa constante associação fez com que ele assumisse uma postura radical contra a Pantomima como forma de diferenciar o seu trabalho:

Eu normalmente fico impressionado com todas as formas de arte, e não igualmente impressionado com todas da mesma forma, mas há uma que francamente me desagrada. E essa é pantomima. Pantomima: que o jogo de cara e mãos que parece uma tentativa de explicar algo, mas lhe falta as palavras necessárias. Eu detesto essa forma. (DECROUX, 1974, p. 15)

Encontramos regularmente Decroux citado como "o pai da mímica moderna", expressão questionada por alguns dos seus ex-alunos tanto pelo seu declarado conflito com a "ideia comum de Mímica", como pela origem de seu trabalho, que não vem da tradição da Mímica, pantomima ou commedia dell'arte, mas construído a partir das tradições do teatro moderno e influências como Dalcrose, Delsartes e Craig, vindas da escola de Copeau:

22. "A tentativa de definir a MCD como um estilo distinto dos outros se constitui numa batalha perdida de Etienne Decroux. De acordo com Robinson (1996), Decroux confessa ter-se arrependido de batizar sua arte como 'mímica', já que a filiação se configurou quase como um estigma, a partir da associação com a pantomima, estilo que abominava." (OLIVEIRA, 2011, p. 51)

23. Decroux apud Jaqueline Robinson, op. cit., p.271. 
Antes de se dedicar exclusivamente à arte do movimento, Etienne Decroux era um ator. Ele trabalhou sob a direção de Jacques Prévert, Gaston Baty, Jouvet, Antonin Artaud e, especialmente, na companhia de Charles Dullin. Sua pesquisa se desenvolveu em Edward Gordon Craig e Adolphe Appia traços cujos escritos defender um retorno à visão sugestiva da cena em completo contraste com o naturalismo de Antony e o realismo psicológico de Stanislavski (...). (LEBRETON, 2012. p. 23)

Mesmo com a sua "paternidade" questionada, é inegável a importância da pesquisa de Decroux na construção da Mímica Contemporânea, a sua contribuição aparece mais claramente através de notáveis ex-alunos que buscaram outras aplicações distintas dos ideais de seu mestre, alguns inclusive buscando a inspiração na Pantomima de origem pierrotesca, gênero que tinha o desprezo de Decroux.

Entre esses ex-alunos, podemos destacar Marcel Marceau (1923-2007), que após atuar no papel de Deburau ${ }^{24}$ no espetáculo dirigido por Jean-Louis Barrault ${ }^{25}$, numa exitosa tournée pela Europa, em 1947 criou uma personagem inspirada na tradição da pantomima de face branca, o "Bip", que o acompanhou até o final de sua vida; O trabalho artístico de Marceau, teve um grande êxito, ganhando reconhecimento por todo o globo e acabando por se tornar um sinônimo para a própria Mímica.

Mais sobre essa questão, diz-nos Yves Lebreton:

(...) Apresentam erroneamente Etienne Decroux como "o pai da mímica moderna", pois não há uma relação direta entre a sua pesquisa artística e a linha dos Pierrotino, Gaspar Deburau, os mímicos Severin e George Wague. A Mímica Corporal não é uma modernização da mímica tradicional. Ele nasceu na escola Vieux-Colombier de Jacques Copeau e foi o resultado de uma nova pedagogia de formação focada na revalorização da expressão física do ator. (LEBRETON, 2012, p. 23, tradução nossa)

Decroux cortava relações com ex-alunos que buscaram na tradição da pantomima o seu caminho artístico, não admitindo que durante o seu processo de ensino e treinamento, que

\footnotetext{
24. Jean-Gaspard Deburau (1796-1846), foi um dos mais famosos mímicos da história, e um dos percursores da pantomima "face-branca" inspirada na tradição do Pierrô, atuando no Théâtre des Funambules em Paris, foi imortalizado no filme de Marcel Carné, Les Enfants du Paradis(1945), aparecendo como personagem do filme chamado no palco de Baptiste.
}

25. Barrault dirigiu uma versão teatral do filme de Carné convidando Marceau para fazer o papel de Baptiste. 
nenhum dos seus pupilos/atores fizessem qualquer outro curso ou atividade de teatro fora a sua Mímica Corporal, tendo como punição o banimento de sua escola e o desafeto de seu mestre.

Anunciando de forma messiânica a necessidade da criação utópica da sua catedral da Mímica Corporal, essa "nova arte" ${ }^{26}$ seria uma renovação do fazer teatral, "Decroux começou pela prática teatral e o impulso que o levou a se dedicar exclusivamente a uma prática corporal foi o desejo de corrigir as intoleráveis deficiências fundamentais que ele encontrava no teatro e nos atores de sua época." (MARINIS, 2015, p. 188).

O caminho oferecido por Decroux para o que viria a ser essa renovação era demonstrado por suas próprias criações de peças abstratas normalmente com uma narrativa não-linear.

Essa busca utópica de Decroux, a sua obstinação por gerar esse novo teatro se amplificou em sua última fase de ensino/trabalho, após a sua temporada em Nova Iorque, quando diminuiu as apresentações públicas, quase se isolando em sua nova escola, ocupando a maior parte de seu tempo para o ensino e a sua pesquisa, apresentando o seu trabalho quase exclusivamente apenas em sua escola para poucos convidados e "iniciados", aproximando a sua escola da ideia de um "templo" da Mímica Corporal.

(...) na ausência de apresentações públicas, as sessões de sexta à noite eram mais como a formalização de rituais de iniciação na ordem esotérica de Decroux. Richard Schechner fala sobre a distinção entre preparação e ensaio no teatro, dizendo que quanto mais tempo gasto à preparação no lugar de ensaio, mais o teatro se aproxima de ritual (...). (SKLAR, em Zarilli, 2009, p. 118 , tradução nossa)

Foi criado por Decroux um vasto repertório de peças curtas e figuras coreográficas, somente as peças chegam a quase 100 composições (LEABHART, 2007, p. 111), seu processo de criação partia regularmente de improvisos baseados na própria experiência dos alunos para a criação e também na recriação de antigas que se modificavam pelos "buracos na memória" já que não era feito nenhum tipo de registro desse trabalho, e como Decroux criava as peças com a mesma velocidade que as esquecia, apenas algumas sobreviveram pelas raras filmagens e por alunos que continuaram a repeti-las.

26. O próprio discurso de Decroux não é claro sobre essa expressão, em artigos e entrevistas se refere ao seu trabalho algumas vezes como a construção de um novo gênero artístico (nova arte) e outras vezes como uma renovação para o teatro (novo teatro). 
As peças que sobreviveram, seja pelos vídeos antigos ou pela memória de ex-alunos, se tornaram parte do escopo do ensino da própria técnica, tendo a sua reprodução como parte do processo pedagógico de quase todas as escolas atuais, em algumas o aprendizado e a repetição desse trabalho como o objetivo final de seu processo de ensino.

Esse trabalho autoral de Decroux, muitas vezes é apresentado como a manifestação da própria Mímica Corporal aplicada ou como o seu objetivo final (a criação de peças abstratas), isto é mais uma forma de colocar o estilo de criação de Decroux como a encarnação desse "novo teatro". Esse conjunto de afirmações é questionado pelo simples princípio de haver uma diferença entre a obra artística de Decroux e a sua pesquisa pedagógica que não está a serviço "apenas" da reprodução do estilo do seu criador.

As peças criadas por Decroux são suas tentativas de corporificação de seus ideais de uma nova arte, a sua maneira de se expressar e criar utilizando a sua pesquisa, não o fim, afirmar que a Mímica Corporal serve apenas para reproduzir o estilo de seu criador seria um equívoco, e algo extremamente injusto com as possibilidades criativas da própria técnica, engessando-a numa única forma de criação.

Por ter escolhido criar por abstrações e simbolismos se opondo a narrativas lineares e convencionais, o trabalho artístico de Decroux é um pouco hermético em sua forma, "a análise dos críticos confirmam que uma das principais razões para a dificuldade que a Mímica Corporal - também Decroux como interprete - sempre encontrou com o público foi pela negação de qualquer fácil identificação.” (MARINIS, 2015, p. 183).

Essas obras muitas vezes parecem navegar entre a mímica convencional de narrativa mais realista e a dança, “(...) me pergunto se o teatro de Decroux não foi afinal feito para um público inexistente.” (BARBA em LEABHART, 2008, p. 35).

Essas obras também confundiam alguns críticos sobre a natureza de seu gênero, questionando sobre estar mais próximo a dança que ao teatro, algo constantemente negado por Decroux, que associava a dança a movimentos contínuos, fluidos e contra a gravidade (saltos e piruetas), sem a demonstração de esforço, e a sua mímica como a representação do esforço, trabalhando sobre o efeito da luta contra a gravidade sem a fluidez que ele atribuía a dança, afirmando a sua mímica como a "mobilidade imóvel" (LEABHART, 2007, p. 62), mas admitia a proximidade dos dois: 
A arte da mímica é a arte do movimento corporal.

A arte da dança também.

Para deduzir sobre o que foi acima exposto, do ponto de vista de um mundo sentado, estas duas artes são irmãs, exigindo apenas um passo que um filósofo poderia fazer, pela primeira vez, enquanto ele dança (...). (DECROUX,1985, p. 50, tradução nossa)

Decroux era consciente da confusão conceitual que gerava na insistência de imprimir o seu próprio significado para o uso da palavra Mímica, que se diferenciava da ideia comum de imitação ou reprodução do real, "você sabe que as palavras vão pouco a pouco assumindo outro significado como resultado da forma que as usamos" (DECROUX em: LEABHART, 2008, p. 111), tanto que o primeiro artigo escrito de Decroux sobre o seu trabalho, "Minha definição sobre o Teatro", ele não usou a palavra "mímica" ou "corpo" em nenhum momento, também se opondo a usar o termo "gesto", que para ele se aproximava da pantomima e "movimento" que se aproximava da dança.

Encontramos iniciativas de nomear a Mímica Corporal como "mímica abstrata" ou "mímica subjetiva", dois conceitos que reforçam a questão de associar a técnica com o trabalho artístico de Decroux. Essas terminologias começaram a aparecer após suas primeiras apresentações públicas, foram cunhadas por alguns estudiosos de teatro que provavelmente ficaram confusos com o nome Mímica Corporal, já que a obra de Decroux não apresentava nenhuma relação com a ideia comum de mímica até aquele momento, criando uma expressão onde fosse possível colocar dentro da categoria entendida como mímica o trabalho artístico de Decroux.

Recusando-se ao método da imitação superficial e da ilusão (que Marceau e outros logo trouxeram de volta a voga), a mímica de Decroux também resistiu a possibilidade de uma fácil compreensão e identificação por parte do espectador. Isso explica a impressão de um formalismo abstruso, enigmático e de uma técnica árida, excessivamente refinada que as peças de Decroux e suas próprias performances tantas vezes receberem do público (incluindo especialistas), que ficavam claramente frustrados em sua necessidade de empatia e compreensão. (MARINIS, 2015, p. 182, tradução nossa) 
Essas expressões além de semioticamente contraditórias e discutíveis promovem uma enorme injustiça com a própria técnica, pois, além de indicar um fim específico de composição cênica, que se relaciona com o gosto pessoal de Decroux, são termos que reduzem a criação restringindo a mímica dentro de uma situação binária, subjetivo versus objetivo, abstrato versus concreto, algo que não cabe dentro do fazer teatral contemporâneo. Pensar e tentar colocar a criação dentro de "uma caixinha binária" limita profundamente as possibilidades criativas e o desenvolvimento dessa arte impondo limitações absurdas na expressão e rótulos desnecessários.

Existem subjetividade e abstração em toda a forma de mímica, mesmo as que lidam com a ilusão de objetos invisíveis e narrativas mais lineares, Decroux propunha um estudo da mimese da realidade e não a sua reprodução, essa abordagem da sua mímica chegava a um resultado final mais abstrato e simbólico, mas esse era o seu resultado final, o estudo da mimese do movimento e da ação como processo pode ser aplicado numa obra final de vários gêneros e formatos artísticos, hoje em dia existem companhias de dança, circo, teatro físico, palhaços e inclusive pantomima de cara branca utilizando a técnica criada por Decroux em seu treino/material de criação.

A justificativa de usar "Mímica" como definição de sua pesquisa parte do princípio onde começa o seu estudo, da observação das ações reais relacionadas e na análise da interação do corpo com o seu meio, caminhando para um processo de isolamento das articulações e vetores do corpo e do espaço dentro de um plano geométrico, ou segundo ele, promovendo "uma limpeza",

(...) vamos dizer que sobre tudo, a arte da mímica consiste em uma limpeza, ou se você preferir, uma purificação, O que é limpeza? É manter a essência de alguma coisa. Mas você tem que entender que no começo a palavra "pura" é uma palavra da mente racional, e não um elogio. Isso significa que é uma arte, uma atividade que não foi misturada com outra. (DECROUX em: LEABHART, 2008, p.110, tradução nossa)

Essa limpeza proposta por Decroux consiste no estudo da biomecânica do movimento, estudando as articulações e possibilidades físicas em busca do "drama" das ações pela sua desarmonia. O homem segundo Decroux está constantemente em conflito com seu interno e contra o mundo (tudo aquilo que não é ele), quando esse corpo entra em harmonia consigo e 
com o mundo, ele dança, e quando luta contra a sua desarmonia faz a mímica dramática. E mesmo pregando partir do estudo do concreto e da luta/conflito.

Decroux criava e buscava uma experiência estética pelo "belo e harmônico", se referindo a poesia como princípio de composição corporal, "Nós que somos mímicos temos que tentar fazer poesia através das ações, não das palavras." (DECROUX em: LEABHART, 2008, p. 115), e essa poesia corpórea, segundo as suas preferências, abstrações e simbolismos, que Decroux valorava como algo superior a "vulgaridade" da realidade, "A mímica deve ser estudada a fundo com o objetivo de torná-la uma serva invisível de uma poesia que inclua tudo...” (DECROUX, em: DORCY, 1961, p. 86).

O quase isolamento artístico de Decroux do seu mainstream do teatro em sua época teve seu lado positivo no sentido que ele conseguir trabalhar sem a necessidade de "agradar o público", com total liberdade de experimentar, se aprofundar e organizar a sua pesquisa, mas, por outro lado, esse distanciamento do público e da cena se refletiu em toda uma geração formada diretamente por ele, onde muitos saíram de sua escola repetindo o seu estilo de trabalho hermético, "a Mímica de Decroux também resiste a qualquer possibilidade de fácil compreensão e identificação por parte dos espectadores.” (MARINIS, 2015, p. 182)

Mesmo criando com frequência, Decroux não deixou nenhum registro escrito indicando meios ou metodologias referentes ao processo de composição cênica/corporal, e não é sabido através dos relatos e/ou artigos de quem passou por sua escola da preocupação em dar a autonomia de criação a seus alunos/atores, pelo contrário, encontramos muitos depoimentos, alguns anedóticos sobre o seu grande zelo de não aceitar a utilização de sua pesquisa para algo fora de seus objetivos.

$\mathrm{Na}$ busca de atores que servissem como missionários de sua nova mensagem formouse uma segunda geração preparada fisicamente e ideologicamente para continuar a sua obra. Decroux não se satisfazia em mudar os corpos dos alunos, mas também as suas ideologias, e caso ele descobrisse que alguém o estava traindo com outro "mestre", expulsava imediatamente, não permitindo o seu retorno a escola.

(...) na minha opinião é uma tragédia que ele, Decroux, não era igualmente obcecado pela criação e composição de novas produções, e todas as suas tentativas eram ligadas a sua filosofia-estética que eu não acredito que fosse capaz de atingir e emocionar uma audiência. (BARBA em LEABHART, 2008, p. 34, tradução nossa) 
Decroux ensinou regulamente por quase 60 anos, com centenas de alunos de todos os lugares do mundo passando pelos seus cursos todos os anos, e mesmo assim, hoje existem poucas companhias e coletivos artísticos formados dos seus ex-alunos, encontramos menos de quatro escolas (da segunda geração) em todo o globo que continuaram com o ensino e a pesquisa da Mímica Corporal. Isso pode ser o resultado da falta da preocupação de organização de metodologias de criação e a ausência de interesse em dar autonomia artística aos seus alunos, Decroux era um pesquisador obstinando, e mesmo criando com frequência, não era esse o seu foco principal,

Eu não sou terrivelmente interessado em me apresentar. Não é terrivelmente importante para mim, alguém me dizer que sou um Mímico extraordinário. Mesmo assim eu era talentoso. Isso não interessa a mim. Gênio desaparece. Arte é eterna. (DECROUX em LEABHART, 1997, p. 16)

O hermetismo da obra artística de Decroux, a falta de preocupação com a organização de métodos de aplicação da técnica para a composição cênica junto com a falta efetiva de uma ação concreta para dar a autonomia de criação ao ator - mesmo Decroux pregando a supremacia do ator no fenômeno teatral - levou a acontecer hoje um quase desconhecimento desse treinamento e do seu potencial, tanto devido ao pouco espaço para a discussão sobre as diversas possibilidades de uso dessa técnica na criação cênica e na aplicação em processos de formação de atores.

Esse quadro começa lentamente a ser revertido pela nova geração de "Mimos Corpóreos" - a terceira geração - que, talvez, por não ter tido contato direto com Decroux, trabalhem com mais liberdade, propondo novas formas de criação e realizando algumas iniciativas de ensino e divulgação dessa técnica.

A técnica da Mímica Corporal vai muito além da obra artística de seu criador, tem séries de exercícios e estudos da geometria e articulações do corpo em si mesmo e no espaço, além de observar e reproduzir a biomecânica dos movimentos reais propondo estilizações como forma de ampliar o corpo cotidiano, estudando o deslocamento no espaço as dinâmicas dos movimentos e da energia da ação.

A explicação dada no capítulo III é apenas uma referência para uma primeira compreensão da complexidade e estrutura da parte técnica e conceitual da Mímica Corporal, como forma de mostrar que está muito além apenas da repetição do repertório de criação de Decroux, e também para despertar a curiosidade de leitores que ainda não tenham tido contato 
com a técnica. Para compreender profundamente cada elemento contido na explicação neste capítulo, seria necessário um estudo mais aprofundado que não é o objetivo dessa obra, no DVD em anexo tem pistas sobre alguns desses princípios explicados.

(...) pode o ensino de Decroux continuar se for assimilado pelo teatro dominante? Pode a Mímica Corporal existir como uma entidade separadamente ou é apenas mais uma ferramenta para "treinamento de movimento dos atores"? Decroux preocupado com essas questões tratava dela sempre em suas palestras de sexta à noite. (LEABHART, 2007, p. 38, tradução nossa)

\section{CAPÍTULO II}

\subsection{Sobre o corpo}

Neste capítulo elaboramos de forma resumida uma explicação sobre a questão corpo/mente e identidade dentro da doutrina filosófica de Espinosa para dar o suporte no entendimento do conceito de paralelismo. Não é o objetivo deste trabalho se aprofundar na obra do filósofo holandês. Utilizamos o paralelismo apenas como uma provocação inicial, com o objetivo de despertar a reflexão sobre a afirmação do corpo como identidade.

É um prazer poder iniciar a discussão conceitual por Espinosa, por que foi esse o caminho que nos levou a esse trabalho, foi pelo questionamento trazido pela sua filosofia que deixou mais claro os objetivos e o método de ação para a pesquisa. Vamos dar aqui a nossa interpretação sem fazer comparações com outros filósofos, recortando e apresentando as questões que achamos relevantes desta fabulosa obra²7.

Introduzirei esses conceitos para quem ainda não foi apresentado a esse pensamento e levantando questões para serem discutidas para aqueles que já o conhecem, mantendo a afirmação do corpo como identidade partindo da ideia do paralelismo, onde corpo e mente são uma e a mesma coisa agindo de forma coordenada.

Esse capítulo foi utilizado como roteiro na criação de um exercício cênico e será apresentado junto com a exposição desse trabalho, usamos essa pesquisa sobre corpo-mente e

27. Estudamos aqui o livro "A Ética" e algumas correspondências de Espinosa como referência. 
a sua influência na ideia da individualidade para a criação de um espetáculo-demonstração coreográfico que introduz o espectador nesse universo.

A filmagem dessa apresentação não está no DVD anexo deste trabalho e se encontrará no endereço da internet: "http://spinoza.angatu.net"

Espero que essa pequena introdução a esse fabuloso universo de Espinosa seja tão inspiradora para você como foi para mim.

\subsection{O corpo como identidade}

A negação do corpo como parte da identidade do homem, pela separação e hierarquização entre "corpo e mente" (alma), é algo presente na cultura e pensamento ocidental. Sustentado pelos dogmas religiosos de base judaico/cristã e uma corrente filosófica calçada na metafísica, eles projetam o corpo como um instrumento temporário e descartável de uma "alma" imortal, que é o verdadeiro eu.

A maior influência para esse pensamento vem do filósofo grego Platão, que colocava a alma como uma substância independente do corpo, eterna, unindo-se a ele de forma temporária e acidental (PLATÃO, 1991), compartilhando assim o ascetismo do corpo pregado por Sócrates. Platão criou o conceito da mimésis, onde há um mundo ideal e perfeito, o mundo das ideias e o mundo em que vivemos é uma cópia imperfeita do mundo ideal, essa cópia imperfeita foi criada por um deus artesão, já que para Platão um deus perfeito não poderia ter criado um mundo imperfeito.

Assim ele imaginou uma entidade, o Demiurgo, o responsável pela criação das “cópias" físicas do mundo ideal. Esse é um princípio chave nos conceitos de Platão, pois hierarquiza o mundo material, como sendo uma cópia imperfeita, inferior e o mundo mental (as formas ou ideias) como algo perfeito e superior. Essa perspectiva será retomada em toda a sua filosofia.

Assim, Platão definiu o homem como composto de corpo e alma. O corpo pertence ao mundo imperfeito, enquanto a alma seria o que teríamos mais próximo à perfeição, isto é, do mundo inteligível. Desta maneira, toda a teoria filosófica de Platão irá se basear na divisão entre esses dois mundos: o inteligível da alma e o sensível do corpo. O que é chamado de "pensamento platônico" é essencial para a compreensão de toda uma linhagem filosófica que virá depois, na qual é valorizado o mundo inteligível em detrimento do sensível. 
A alma é detentora da sabedoria e o corpo é a prisão, ou seja, a alma é dominada por ele quando é incapaz de regrar os desejos e as tendências do mundo sensível.

Esse pensamento serviu perfeitamente aos ideais dos filósofos cristãos medievais que, para justificar a sua doutrina ascética de desprezo retiraram o corpo como agente de nossa identidade. Em outras palavras, o homem seria somente uma alma e o corpo, no limite, um invólucro passageiro.

Seguindo essa tradição, o filósofo francês René Descartes (1596 -1650), em sua obra filosófica, refletiu detidamente sobre essa questão, e assim construiu uma metafísica onde ele chama de corpóreo (extensão) o que ocupa espaço e de pensamento o que não ocupa espaço. Instaurando assim o que foi chamado de dualismo substancial, onde existem duas substâncias distintas: a mente, ou a substância pensante (res cogitans) e o corpo, ou a substância extensa (res extensa).

Forneceu, sem dúvida, um pouco mais de "espaço" para o corpo na identidade do homem, mesmo afirmando que o pensamento está "preso" a esse fragmento de extensão (corpo), assume que da mesma forma que a alma move o corpo, pode ser influenciado por ele, "assim é o homem cartesiano: um composto de duas substâncias - corpo e alma, mas determinado essencialmente por uma - a mente (...)" (SANTOS, 2009, p. 45).

Neste sentido, o ponto de aplicação da alma sobre o corpo seria a chamada glândula pineal. Mas ele não esclarece, de fato, sobre a união da alma e do corpo, e a sua abordagem ainda coloca de forma hierárquica a alma (mente) sobre o corpo.

(...) pelo próprio fato de que conheço com certeza que existo, e que, no entanto, noto que não pertence necessariamente nenhuma outra coisa à minha natureza ou à minha essência, a não ser que sou uma coisa que pensa, concluo efetivamente que minha essência consiste somente em que sou uma coisa que pensa ou uma substância da qual toda a essência ou natureza consiste apenas em pensar. E, embora talvez (ou, antes, certamente, como direi logo mais) eu tenha um corpo ao qual estou muito estreitamente conjugado, todavia, já que, de um lado, tenho uma ideia clara e distinta de mim mesmo, na medida em que sou apenas uma coisa pensante e inextensa, e que, de outro, tenho uma ideia distinta do corpo, na medida em que é apenas uma coisa extensa e que não pensa, é certo que este eu, isto é, minha alma, pela qual eu sou o que sou, é inteira e verdadeiramente distinta de meu corpo e que ela pode ser ou existir sem ele. (DESCARTES, 1991, p. 166) 
Este dualismo radical de Descartes relega mais uma vez dentro da história da Filosofia Ocidental o corpo como forma inferior, Descartes inicia a Filosofia moderna, carregando conceitos tão antigos como a própria filosofia, o homem é um ser pensante, sua essência é espiritual, pois repousa sobre a alma, tese defendida por Platão (SANTOS, 2009, p.48), concebendo o corpo como apenas um invólucro passageiro, e a composição do homem concentrada em sua mente.

(...) a natureza me ensina, também, por esses sentimentos de dor, fome, sede, etc., que não somente estou alojado em meu corpo, como um piloto em seu navio, mas que, além disso, lhe estou conjugado muito estreitamente e de tal modo confundido e misturado, que componho com ele um único todo. (DESCARTES, 1991, p.166)

Quando finalmente chegamos a Baruch de Espinosa (1632-1677), aparecendo com uma forte crítica à filosofia cartesiana e com um pensamento inovador em vários âmbitos, mesmo aparentemente continuando a defender o corpo e mente como elementos distintos, pois "Espinosa também não vê nada de racional na afirmação da alma movendo o corpo ou vice-versa." (SANTOS, 2000, p.53).

Ele afirma que estes dois são na verdade atributos de uma mesma substância original, posição questionadora na história da filosofia, afirmação que iria contra a ideia de hierarquização da mente como algo superior ao corpo, abrindo caminho para uma discussão que continuará pelos anos seguintes de sua morte.

Em sua metafísica, Espinosa demonstra a existência de uma causa imanente (causa em si), que se autogera e cria todo o universo. Esse deus ou Natureza (natura naturans) é a única substância que existe e compõe todo o universo; essa substância infinita e absoluta é dotada de infinitos atributos, mas o intelecto humano só pode conhecer apenas dois deles: o pensamento e a extensão. Esses atributos são infinitos e se manifestam por infinitos modos finitos.

Assim o homem, como a união de dois modos finitos de dois atributos infinitos de uma substância única, a mente e o corpo, não são mais duas substâncias diferentes e sim dois atributos diferentes da mesma substância. Espinosa afirma: “...a substância pensante e a substância extensa são uma só e a mesma substância, compreendida ora sob um atributo, ora sob outro" (SPINOZA, 200, p. 55).

Por esse modelo, a interação do corpo e da mente necessita de uma nova forma, os dois não são mais duas substâncias diferentes que interagem entre si, mas uma única 
substância manifestando-se em modos diferentes, assim, de agora em diante sua relação se dará por meio do que Espinosa chama de paralelismo, "a ordem e a conexão das ideias é a mesma que a ordem e a conexão das coisas" (SPINOZA, 2009, p. 55). Esta relação intrínseca do corpo e da mente se dá agora num nível substancial. Então, o que acontecer com o corpo vai necessariamente acontecer com a mente e vice-versa.

\subsubsection{Uma única substância}

O ponto inicial no sistema metafísico Espinosano e a ideia de substância, a qual o autor define como, aquilo que existe em si e por si mesmo é concebido, isto é, aquilo cujo conceito não exige o conceito de outra coisa do qual deva ser formado (SPINOZA, 2009, p. 13). Esta substância tem como características infinitude, indivisibilidade, unicidade, liberdade e eternidade.

Como causa de si mesma e de todas as coisas consistindo de um número infinito de atributos, aos quais apenas dois, pensamento e extensão, são cognoscíveis pela inteligência humana. Espinosa identifica esta substância como Deus ou natureza, um ente absolutamente infinito, isto é, a substância que consta de infinitos atributos, cada um dos quais exprime a essência eterna e infinita (SPINOZA, 2009, p.13).

Espinosa pregava que esta substância única é uma causa $s u i^{28}$, diferenciando o uso do termo do conceito escolástico, que afirmava normalmente a existência de diferentes substâncias, colocando a materialidade como uma substância distinta da substância divina.

Nas palavras de nosso autor, "por causa sui entendo isto, cuja essência envolve a existência; ou seja, isto cuja natureza só pode se conceber como existente" (SPINOZA, 2009. p. 13).

Espinosa propôs assim em seu conceito de causa sui a integração de todo o universo, quando esta substância primordial se gera, ela gera o todo, não há mais espaço hierárquico substancial no universo uno Espinosano.

Ao falar sobre atributos distintos, ou em seu gênero, Espinosa está fazendo uma abstração mental, posto que os atributos não constituem entes reais; eles não tem realidade própria. Isto é, eles só têm realidade nominal. Trata-se de uma abstração intelectual para se referir a uma natureza determinada da substância. (SANTOS, 2009, p.109)

28. “Causa de si mesma”, quando a substância se gera, gera tudo no universo. 
Os atributos assim não podem ser considerados como "parte" da sustância, mas são seus gêneros, a sua expressão, pois essa substância é absolutamente infinita no sentido de que não há nada além dela. Os infinitos atributos podem ser finitos em seus infinitos modos ${ }^{29}$ finitos.

O modo de um atributo não passa de uma afecção sofrida por este, "as coisas particulares são as afecções dos atributos da substância, ou seja, maneiras pelas quais os atributos de Deus (ou natureza) se exprimem de maneira precisa e determinada." (SPINOZA, 2009, p. 33). Os modos são afecções sofridas pela substância e são coisas particulares limitados e finitos, eles são a última parte da cadeia causal da substância Espinosana.

As afecções não se causam: eles dependem de outra coisa, tanto para ser, quanto para serem concebidas; elas constituem efeitos de uma causa externa, ou seja, uma causa que não se encontra e nem se explica pelo efeito. Em outras palavras a característica básica das afecções é que elas são em outra coisa, tanto realmente quanto conceitualmente, ora, mas não é este o significado do termo modo? Então Espinosa faz uma perfeita identificação entre modo e afecções da substância? (SANTOS, 2009 p.59)

Mas mesmo os modos dos atributos da substância sendo particulares e finitos, não são estáticos e estão em movimento contínuo, como podemos observar no modo extensão no qual a matéria está em constante criação e degeneração, ou no modo pensamento, no qual as ideias estão em constante fluxo, temos uma dinâmica rede causal. Espinosa propõe um universo onde os modos estão em constante transformação.

(...) se todo corpo está sempre em movimento - tanto mais rapidamente, tanto mais lentamente, tudo no universo estará em uma certa quantidade de movimento, mesmo a matéria sem massa. Isso se justifica pela causa do Universo que é a causa sui, cuja a essência é ativa (...) (SANTOS, 2009, p.141)

Esta rede causal proposta por Espinosa dos modos segue uma relação onde os modos podem afetar e serem afetados em cadeia dentro do seu próprio atributo, isto é, objetos extensos podem se relacionar de forma causal apenas com objetos extensos, ideias apenas com ideias. Para Espinosa atributos diferentes não podem ter relações causais entre si, "cada atributo da substância deve ser concebido por si mesmo". (SPINOZA, 2009, p. 18).

29. "Por modo eu compreendo as afecções de uma substância, ou seja, aquilo que existe em outra coisa, por meio da qual é também concebido." (SPINOZA, 2009, p. 13) 
Mas mesmo assim não podemos dizer que Espinosa propõe um universo que é dualista, pois no final todos os modos são manifestações particulares dos atributos de uma única substância, tudo é a manifestação de uma única e mesma coisa, o universo é uno, mas age pelos diferentes modos de seus atributos.

Assim abre-se uma questão importante: se os atributos diferentes não se podem relacionar de forma causal, como pode ocorrer a interação entre eles, por exemplo, no caso da relação mente e corpo no homem? Espinosa responde esta questão com a tese do paralelismo.

\subsubsection{Paralelismo}

Como é que um pensamento ou ideia pode criar uma representação sobre um determinado objeto? Responder essa pergunta é o primeiro passo para a compreensão da questão “corpo e mente" proposta por Espinosa. Pois todas as características do "estado mental" são ou derivam totalmente das suas características de representação desta forma, a ideia de representação para Espinosa não é só uma representação constitutiva do mental. Para compreender isso é necessário ser explicado o que Espinosa chama de "Paralelismo". "A ordem e a conexão das ideias é a mesmo que a ordem e a conexão das coisas" (SPINOZA, 2009, p. 55).

Para Espinosa, existe uma cadeia causal de modos de extensão, para qualquer coisa extensa $\mathrm{x}$, que seja causada por outra coisa extensa $\mathrm{y}$, existe uma ideia de $\mathrm{x}$, que é $\mathrm{x}$ ou representa sobre x. Essa ideia é causada pela ideia de y que, por sua vez, é causado pela ideia de causa y, etc. A mesma regra é aplicada para todas as coisas extensas e, portanto, existe uma cadeia causal de ideias que é isomórfica e que tem a mesma ordem e conexão como na cadeia de coisas extensas representadas por essas ideias. "Nem o corpo pode determinar a mente a pensar, nem a mente pode determinar o corpo ao movimento ou ao repouso ou a qualquer outro estado (se é que isso existe)". (SPINOZA, 2009, p. 53)

Este espelhamento elaborado entre a extensão e o pensamento é o corpo. Assim se dá a separação explicativa e causal de Espinosa para estes dois atributos diferentes: as ideias entram em relações causais só com outras ideias, assim como o modo extensão só entra em relações causais com outros modos de extensão.

Em primeira instância, o paralelismo de Espinosa pode parecer de alguma forma, como uma visão cartesiana, principalmente quando mantém as cadeias de causalidade do 
modo extensão, como algo separado da cadeia causal do modo pensamento, negando qualquer ligação explicativa sobre uma possível conexão entre corpo e mente como sugerida por Descartes em sua filosofia. Mas, precisamente essa separação proposta por Espinosa, que aparentemente parece aproximá-los, é algo que distingue os dois.

\begin{abstract}
Apesar de bem distintas, as teses de Descartes e Espinosa parecem se confundir algumas vezes pelo uso de termos semelhantes ou mesmo iguais. No entanto, que o leitor não se engane o sentido é bem distinto. Por exemplo, Espinosa diz que o homem é constituído de Corpo e Mente; enquanto que para Descartes, ele é um composto de um corpo e de uma alma (ou mente). (SANTOS, 2009, p. 53)
\end{abstract}

Para Espinosa, cada ideia e modo de extensão, mesmo sendo distintos e paralelos, têm a mesma origem, "são uma só e a mesma substância" (SPINOZA, 2009. p. 55). Assim por sua visão monista ${ }^{30}$, Espinosa une as duas categorias substancialmente, que mesmo distintas em seus modos e atributos, são uma mesma coisa (substância) manifestada de formas diferentes, mas agindo ao mesmo tempo e sem cadeias hierárquicas entre si.

3.2.3 A ideia do corpo

A mente humana é uma parte do intelecto infinito de Deus. E, assim, quando dizemos que a mente humana percebe isto ou aquilo não dizemos senão que Deus, não enquanto é finito, mas enquanto é explicado por meio da natureza da mente humana, ou seja, enquanto constituí a essência da mente humana, tem esta ou aquela ideia. (SPINOZA, 2009, p. 59)

O ponto geral é bastante claro: nós temos uma espécie de consciência de nossos próprios corpos que nós não temos de outros organismos, mostrando também que a mente humana não representa outra coisa que não o seu próprio corpo, isto é, temos esta consciência de nossa individualidade pelas diferenças entre os corpos. Neste sentido, nossa noção de

30. Monismo (do grego mónos + -ismo) - Doutrina filosófica segundo a qual o conjunto das coisas pertencem a uma unidade, que pode ser pelo ponto de vista da sua substância, ou pelo ponto de vista das leis (lógicas ou físicas) pelas quais o universo se ordena. 
individualidade vem pelo conhecimento de nosso corpo, por nossa ideia ou representação mental do corpo, por isso a mente humana, assim como o corpo humano, são indivíduos (na verdade, eles são o mesmo indivíduo).

Também assim, podemos dizer que para Espinosa o que faz um corpo ser o nosso próprio corpo é simplesmente que a nossa mente o representa. A ideia de representar um corpo é a ideia de representar um corpo colocado dentro de uma "rede causal", composta por diversos corpos com a origem na mesma substância, ou seja, se tudo tem uma ligação íntima na origem que une o todo, percebemos os limites que compõem a nossa individualidade na representação do corpo no pensamento, assim a "posse" de um corpo deve ser explicada em termos da noção de representação, isto é, a mente é a ideia do corpo e o corpo é conhecido por sua representação.

O corpo pode ser dito uma parte da substância apenas abstratamente, ou seja, uma maneira de pensar que nos faça compreender que ele não representa $o$ Todo da Natureza, mas que também não pode ser ou estar fora dela: ele é nela; ela o contém e o constitui. A percepção (conhecimento imperfeito) se dá pelos sentidos: através deles, percebemos os corpos separados um dos outros, não somos capazes de ver como os corpos constituem um só todo - A Extensão - que não admite divisão, digo separação entre um corpo e os outros. (SANTOS, 2009, p.190)

Esta íntima relação na composição de um indivíduo não gera ou faz necessária a criação de uma relação causal entre os dois, pois diferente do ideal proposto por Descartes que em seu dualismo substancial foi preciso encontrar um "local" de encontro entre as diferentes substâncias ${ }^{31}$, aqui, como os dois são a mesma coisa, uma mesma substância agindo por seus diferentes atributos, não é necessário encontrar um ponto comum de comunicação.

Podemos compreender assim a importância dos dois modos dos dois atributos na composição do homem, não existe o homem sem um corpo e uma mente. $\mathrm{Na}$ verdade, o homem apenas aparece quando os dois agem juntos pelo paralelismo, algo extremamente complexo de se compreender. Aparece de certa forma como mundos distintos, os dois apenas parecem distintos, pois são parte de uma única substância e concebidos ao mesmo tempo.

31. Descartes sugere em sua obra que o local de encontro entre a alma e o corpo seria na glândula Pineal, por onde os dois se comunicariam. 
O corpo está determinado a se movimentar ou repousar, a se juntar a outros corpos formando um indivíduo maior, mais forte e mais ativo; ele está determinado a existir por uma duração de tempo e a lutar para permanecer no seu ser por tempo indefinido; ele está determinado a afetar e ser afetado; ele está determinado a se utilizar e ser utilizado por outros corpos; a destruir e ser destruído por outros corpos, mas nada disso é ruim, pois tudo revela da essência mesmo de Deus, que é ativa e causa de todas essas determinações. (SANTOS, 2009, p.158)

Assim podemos dizer que não existe o corpo do homem por si só, como não existe a mente do homem por si mesma, o modo do atributo extensão vai aparecer como corpo junto com a sua ideia deste corpo, o modo do atributo pensamento. Essa união substancial é uma das mais fascinantes e complexas proposições propostas por Espinosa que não apenas foi contra a tradição de ignorar a importância do corpo na composição do homem, hierarquizando o "mundo menta" como superior ao "mundo físico", mas colocando a importância necessária desta composição: modos distintos atuando em conjunto sem ordens prioritárias, pensamos e ocupamos espaço e só existimos da maneira que existimos por conta disso.

Assim podemos colocar que, por esta maneira de encarar o conceito de indivíduo dentro da metafísica Espinosista, ele seria visto apenas como um ponto de transição no movimento eterno do pensamento e a realidade substancial de um indivíduo, seria uma ilusão dentro do conceito substancial monista, onde existe apenas uma única substância, expressa em atributos e modos.

Desta forma segue-se logicamente que cada corpo/mente, isto é indivíduo, na medida que exista sobre uma certa definição dentro das modificações dos atributos da substância, deveriam, por este ponto de vista, serem considerados como uma mera parte de um universo uno e, de acordo com esse todo, apresentar uma íntima união com todas as outras partes, já que a natureza de todo o universo não é limitada, mas completamente infinita.

\subsection{O corpo não é uma ferramenta}

A principal proposição sustentada pelo dualismo é a existência de uma diferença fundamental entre o físico e o mental, entre mente e matéria. Essa proposição choca-se frontalmente com as expectativas da ciência contemporânea, que tem buscado, incessantemente, uma explicação para a 
natureza dos fenômenos mentais através do estudo do funcionamento cerebral dos seres vivos. Para a ciência, nossos corpos e, sobretudo, nosso sistema nervoso são parte do mundo físico e, na medida em que alterações da mente não podem ocorrer sem uma alteração correspondente no cérebro, não haveria nenhuma razão a não ser nossa ignorância científica provisória para supor que mente e cérebro devam ser radicalmente distintos. Dessa perspectiva, o dualismo só seria sustentável como parte de alguma crença religiosa. (TEIXEIRA, 2000, p. 78)

Partindo do princípio de relação não causal entre corpo e mente e de uma relação não hierárquica, podemos ir um pouco adiante definindo o "mundo mental" como uma representação do "mundo físico", Espinosa afirma na proposição 23 da Ética II: “A mente não conhece a si mesma senão enquanto percebe as ideias das afecções do corpo.”, essa representação mental é construída através da interação do corpo no meio, de como ele é afetado por causas externas; Já o neurocientista francês Alain Berthoz, acha melhor usar o termo "simulação" no lugar de "representação" para se referir ao processo mental, explicando que o cérebro funciona como um simulador, criando os modelos mentais do corpo e do mundo, modelos atualizados constantemente com as informações recebidas regularmente pelos sentidos.

Para mim, o cérebro é um simulador no sentido de um simulador de voo e não no sentido de uma simulação feita por um computador. Simulação significa que a ação por inteira está sendo orquestrada no cérebro por modelos internos da realidade física que não são operações matemáticas, mas neurônios reais que tem como propriedade forma, resistência, oscilação e amplificação faz parte do mundo físico, afinado com o mundo externo...

(...) Quando falo de simulação, eu quero dizer um conjunto de operações conduzidas por um simulador, uma máquina real que tem, pelo menos, uma porção das propriedades da realidade física...

(...) A palavra "representação" está muito contaminada com a ideia da imagem visual...

(BERTHOZ, 2000, p. 22, tradução nossa)

Defendemos que é necessário abandonar a ideia de dualismo instrumental ${ }^{32}$ antes de entrar na sala de ensaio/treinamento, assumindo o movimento como um dispositivo composto

32. Corrente dualista que instrumentaliza o corpo, o imaginando-o como uma "ferramenta" movida pela alma. 
de ação e subjetividade ${ }^{33}$, pensar no corpo como parte de um processo complexo que compromete também o sensível, realizar um movimento é uma ação que envolve tanto a parte motora do cérebro como a parte criativa em um sistema que engloba: agir, planejar e prever. Essa percepção ampliada é uma "percepção que é mais que uma interpretação de mensagens sensoriais. A percepção é forçada pelas ações; e é uma simulação da ação. É julgamento e tomada de decisão e também é a antecipação das consequências das ações" (BERTHOZ, 2000, p. 9)

Assumindo corpo e mente como uma única entidade trabalhando em uníssono, mover é uma ação repleta de subjetividades que são partes indissociáveis da ação. Para o corpo se mover acontece um complexo processo mental que envolve a subjetividade, "todos os conteúdos de nossa mente são subjetivos" (DAMÁSIO, 2000, p. 165).

Por isso é necessário estar em um estado de escuta sensível sem a real necessidade da busca por "preenchimento" do movimento, este já está cheio de sentido, que será encontrado pela sensibilização dos canais expressivos, permitindo que a subjetividade seja percebida, pois os processos mentais vão acontecer de forma condicional, mas a "atenção" ou consciência da ação a esses processos pode estar associada ou desassociadas, estar "presente" e consciente desses processos é um exercício de concentração constante.

Para compreender na prática esse conceito, é necessário estar alinhado com o ideal da relação corpo/mente contra a cultura dualista, pensar é mover-se, mover é pensar, esse princípio do corpo-pensante, abre o caminho para a investigação da subjetividade da ação que virá junto com o movimento, assim não existe uma ação "desconectada" de sua subjetividade, o que pode ocorrer é uma falta de escuta do sensível, quando a consciência se desvincula do momento, ignorando os processos focando em memórias ou projeções não relacionadas ao momento da ação.

A priorização na forma externa, a supervalorização da imagem sobre o sensível, vem diretamente de uma ideologia de fundo dualista, quando se divide e se hierarquiza a questão mente/corpo, e independente da parte que será colocada como mais importante, as duas saem perdendo.

33. Chamamos de subjetividade os processos internos (não observáveis). "Forma-se, com isto, uma distinção preliminar entre interno e externo, entre "eu" e "não eu", a partir de uma segregação entre dois tipos de sistema nervoso efetuada pela seleção neuronal, um para efetuar o registro interno e outro para efetuar o externo. Distinguir entre o interno e o externo é tarefa vital para a sobrevivência de alguns organismos, mas isto não seria possível se essa segregação inicial não viesse acompanhada, posteriormente, de uma coordenação entre esses dois tipos de sistema nervoso.” (TEIXEIRA, 2000, p.137) 
Tanto a negação do corpo em prol do sensível como a negação do sensível em prol do virtuosismo corporal são formas de hierarquização vindas da cultura de divisão entre corpo e mente. Por isso achamos importante colocar essa questão, quando se entra na sala de ensaio/treinamento, pois a crença existente em nosso imaginário sobre essa relação(corpomente) vai definir nosso conceito de identidade e assim interferir diretamente em como nos movemos, criamos e atuamos. Isto não é apenas um elemento importante para ser discutido, é a base de todo o trabalho que virá.

Essa afirmação não é um pedido de doutrinação aos participantes de processos corporais. Não é necessário que todos acreditem na mesma coisa, porém, que estejam abertos à reflexão de como isso influência todo o trabalho de treinamento, criação e atuação. Para que essa discussão aconteça, é importante ter um leque conceitual de possibilidades.

Escolhemos aqui usar o pensamento de Espinosa, mas existem diversos outros pensadores que também se dedicaram a essa questão, e diversas linhas teóricas que afirmam a importância do corpo que podem ser usados conforme o gosto pessoal e as crenças de cada um.

Essa reflexão é principalmente importante em processos de formação onde o corpo e a sua expressividade serão explorados. Assumir essa questão como parte do estudo - e a sua reflexão - só tem a acrescentar aos processos de aprendizado no qual, no treinamento prático, o aluno irá criar ou modificar a sua "representação" mental de seus esquemas corporais no processo de adquirir uma nova habilidade especializada. Esse processo só terá a ganhar com essa reflexão, pois "habilidades especializadas não representam apenas um rol de procedimentos, mas toda uma cultura formada em torno dessas ações.” (SENNET, 2009, p. 124)

3.4 A Aplicação do paralelismo ao treinamento:

No início da pesquisa prática, quando entramos na sala de ensaios, procuramos levar o ideal de paralelismo proposto por Espinosa para a realização dos exercícios e para o estudo da relação corpo/mente durante a realização dos mesmos, mas tentar levar esse conceito como um "regra” nos limitou e restringiu o trabalho sensivelmente, levando nossa atenção e energia em tentar conseguir seguir essa regra no lugar de desenvolver a potência cênica da prática e/ou aplicá-la para a criação cênica, por isso resolvemos abandonar os conceitos de Espinosa como “regras” e levá-los como poética, inspiração para começar a discussão sobre os nossos 
processos e questionar os nossos conceitos já preconcebidos, carregamos a ideia de paralelismo em todo o percurso, mas ficamos livres para subvertê-la se necessário.

\subsection{Repetir e sentir}

Não tive o privilégio de encontrar pessoalmente Etienne Decroux, depois que descobri a sua obra, pois ele já havia falecido há alguns anos. Vim conhecê-lo pelo relato de seus exalunos e pelos poucos escritos que deixou. Durante meu processo de aprendizado da sua técnica, pelas escolas e profissionais da segunda geração que tive a oportunidade de conhecer e estudar, escutava quase que diariamente histórias anedóticas sobre esse excêntrico criador.

Alguns o apresentavam como uma espécie de mestre, outros como um cientista obcecado em seu laboratório-porão, outros ainda o apresentavam como um grande parceiro de trabalho. Tantas histórias e depoimentos de uma personalidade explosiva e fascinante que, em um curto período, me transformei em "um arqueólogo" da história e pensamento de Decroux, esquecendo o porquê eu resolvi estudar essa técnica e o que realmente me importava: aprendê-la para a criação de um trabalho corporal e autoral.

Decroux por ter deixado pouquíssimos escritos e todos numa linguagem mais poética que objetiva, se transformou para mim numa figura emblemática, o acesso as informações sobre a sua obra, se dá por relatos de ex-alunos. A sua vasta criação coreográfica, exercícios e práticas, também sobreviveram pela memória de seus alunos. Como ele teve várias mudanças em seus mais de 50 anos de ensino/pesquisa, existem também algumas divergências entre eles.

Praticamente todos os artigos, depoimentos e declarações de ex-alunos sobre Decroux disponíveis se focam prioritariamente sobre os seus anseios de um novo teatro. Fala-se muito sobre a sua personalidade explosiva e pouco sobre a prática da Mímica Corporal, se gasta mais tempo tentando achar uma categoria para a Mímica Corporal, "nova arte", "Mímica abstrata", "Mímica Subjetiva", entre outras expressões, do que compreender os elementos da própria prática, estudando a sua aplicação na criação cênica, formação e preparação de atores e bailarinos. Talvez a forte personalidade de Decroux tenha suplantado a sua própria obra.

A Mímica Corporal não é um estudo secreto, mesmo que nunca tenha sido uma forma muito popular. A personalidade "revolucionária puritana" de Decroux desencoraja os meramente curiosos, e a sua arte parece esotérica para muitos. "A pequena, estrita ordem sagrada" de Decroux permanece fora 
do "mainstream", porque ele está menos preocupado em entreter espectadores do que com a transformação de seus alunos - mentalmente e corporalmente - em sua imagem idealizada do ator-prometeico. Este ideal é conseguido através do domínio físico da técnica do Mimo Corpóreo e através de assimilação de seus princípios teóricos.

Os alunos que permanecem com Decroux tempo suficiente para dominar o seu sistema tem sofrido um processo de desconstrução e reconstrução que mais se assemelha ritual de iniciação do que teatro. (SKLAR, 2002, p. 160, tradução nossa)

Essa adoração quase que messiânica da personalidade de Decroux, uma figura indubitavelmente fascinante, não acredito ser algo realmente útil para a promoção da técnica e nem para a sua aplicação no teatro contemporâneo. Colocar o foco do entendimento sobre a Mímica Corporal na interpretação das suas ideologias declaradas e não na sua obra prática, pode isolá-la em alguns poucos apaixonados por esse espírito de "seita iniciática" que permeia em torno da técnica criada pelo excêntrico francês.

Como reflexo deste processo de "mistificação" da personalidade de Decroux, a sua obra artística, as peças e figuras corporais abstratas, o "repertório de Decroux", recebe em alguns processos de formação de novos "mímicos corpóreos" um destaque especial, valorando a sua memorização e repetição correta como o final do aprendizado, e/ou colocando como objetivo criativo do treinamento a criação de peças corporais abstratas copiando o estilo artístico de Decroux.

Ele deixou algumas normas para a criação e execução de peças corporais, este conjunto de regras normalmente são colocadas dentro do "pacote" como parte da própria técnica ou como a própria definição da Mímica Corporal. Não vamos entrar aqui na longa discussão sobre a validade desta questão, se o treinamento da Mímica Corporal serve a este propósito e se essa seria a "nova arte" de Decroux.

Em minha abordagem sobre a técnica, em minha prática, isolo aquilo que é referente ao estilo de criação do mestre francês dentro do sistema da técnica, para aproveitar aquilo que servirá ao meu propósito com esta pesquisa. Isto é, realizar um treinamento voltado a dar autonomia de criação e promover uma dilatação das possibilidades expressivas de cada praticante sem prendê-lo a uma estética específica. Em minha opinião, essas regras propostas por Decroux, para a criação de cenas, fazem parte de uma busca por um resultado estético 
específico, algo que não interessa a este estudo. Ao contrário, busco alternativas para libertar a criatividade e possibilidades de criação cênica.

Das regras propostas por Decroux, podemos destacar algumas das principais:

- Estética não-realista e expressão por metáforas

Diferenciando esse trabalho do conceito tradicional de mímica onde se representa o real, aqui o objetivo é criar metáforas e representações abstratas do real. “...mímica deveria representar/apresentar, além de fatos concretos e ações materiais, os "movimentos da alma" e toda a "vida da mente". Em outras palavras deveria expressar (de uma forma despersonalizada e essencial) os sentimentos, paixões e pensamentos que estão por trás desses fatos e dessas ações...” (MARINIS, 2015, p.153, tradução nossa)

“A Mímica age e produz realidade não a reproduz, cria seu próprio mundo no lugar de se tornar passivamente encantada pela realidade apresentada." (MARINIS, 2015 , p. 28, tradução nossa)

- Metáfora ao avesso

A metáfora ao avesso é uma proposta estética de criação dentro do ideal abstrato (não-realista), um conjunto de regras que se focam na representação abstrata de algo concreto (também pode-se partir de ideias, sentimentos e sensações), "com o propósito de atingir ideias ou emoções que estão em um plano abstrato e que sempre poderão ser interpretadas de diferentes maneiras. $O$ trajeto de construção da metaphore à l"envers acontece, portanto, do concreto para o abstrato, não do abstrato para o concreto." (MASCARENHAS, 2007, p. 77)

- Equilíbrio instável e a luta contra a gravidade

Para Decroux, manter o equilíbrio instável era uma forma de manter o "drama da ação", pela eterna luta contra a gravidade e como demonstração de processos do pensamento. “(...) o artista mímico precisa atuar em condições de uma permanente instabilidade precária, que é desequilíbrio, porque isto é a única forma de produzir a tensão necessária na ação para fazê-la viva e eficaz.” (MARINIS, 2015, p.156) 
- Predominância do torço

O torço (quadril, cintura e peito) tem prioridade na expressão, "na mímica corporal, a hierarquia dos instrumentos de expressão são os seguintes: primeiro o corpo, depois os braços e as mãos e por último o rosto" (DECROUX, 1985. p. 68)

- A despersonificação do intérprete.

Decroux defendia que o ator não deveria mostrar a sua natureza e que seu corpo estivesse em função da representação de algo "além de sua personalidade", "O artista deverá mostrar a sua criação sem mostrar a sua persona” (DECROUX, 1985, p. 87)

Estabelecendo este limite entre a parte dedicada a reprodução da estética de Decroux e o treinamento expressivo, vamos nos focar na parte que nos interessa: o treinamento aplicado ao desenvolvimento da autonomia corporal do artista cênico.

Quase todas práticas corporais que partem da metodologia observação/repetição, realizam o aprendizado da técnica pela cópia de poses, gestos, exercícios estilizados, onde a repetição constante é necessária. Normalmente nesses processos de aprendizado, o parâmetro para avaliar uma realização correta é conseguir copiar o mais próximo possível as formas observadas num outro corpo que não é o seu.

(...) Não um treinamento entendido como repetição formal de movimentos, mas a execução atenta de instruções com a intenção de reforçar os novos caminhos propostos para a flexibilização de padrões e a criação de movimentos. Transformações no corpo são possíveis através de reforços constantes de determinadas ações. Isto não quer dizer que este reforço é feito na prática de repetições mecânicas e desatentas. Muito pelo contrário, para a qualidade da implementação de novos comportamentos na execução de movimentos é necessária a atenção focada, com o intuito de se perceber as possibilidades de movimento envolvidas e as mudanças de estado relacionadas. De outra maneira não poderia ser, uma vez que a compreensão da não separação mente/corpo é fundamental neste trabalho. (NEVES, 2010. p. 54) 
Após concluir o curso na International School of Corporeal Mime ${ }^{34}$, me confrontei com essa questão. Após alguns anos repetindo quase que diariamente essa prática, já sabia executar várias peças e figuras e outros exercícios de Decroux, mas não sentia a autonomia para criar um trabalho autoral. Esse novo repertório de movimentos foi algo tão forte, que mesmo em improvisos livres, acabava realizando colagens utilizando partes e fragmentos de gestos e formas dentro do que tinha aprendido.

Durante esse período de formação, tive contato com algumas práticas voltadas para a composição cênica, mas estas ainda continham limitações rígidas na criação, carregando expectativas de um resultado final estético e estilização próxima à prática dos exercícios, com a regra de manter a fidelidade ao estilo de criação abstrata proposta por Decroux. Aprender utilizar a técnica para criar de forma fluida e livre foi algo que tive que descobrir fora das escolas de Mímica Corporal, através de contato com outras práticas e bastante reflexão sobre esse trabalho.

Assim podemos concluir que práticas corporais muito fechadas podem restringir as possibilidades de movimentação de seus praticantes para dentro dos limites dessa mesma prática quando trazem junto conjuntos de regras e ações prontas. Mesmo apresentando uma gama quase infinita de combinações possíveis entre seus movimentos definidos, "várias regras podem restringir a maneira em que os movimentos podem ser executados da mesma maneira que as regras gramaticais vão limitar o número de frases corretas." (HAGENDOORN, 2010, p.223). Isso não é um problema se o objetivo for criar apenas dentro desse repertório.

Seguindo essa lógica, podemos aceitar que é possível realizar práticas de repetição e imitação sem necessariamente ter regras rígidas para sua utilização. Buscando formas dinâmicas de realizar essas práticas, o sociólogo Richard Sennett nos dá algumas pistas em seu livro "O Artífice", quando discorre sobre a aquisição de novas habilidades através da repetição: "melhorar uma técnica nunca é um processo mecânico, de rotina" (SENNET, 2009, p.36). Aproximando a ideia de treinamento como desenvolvimento de habilidades, Sennett ainda propõe ainda que uma habilidade é uma prática treinada, “...o desenvolvimento de uma habilidade, depende de como a repetição é organizada... E quanto mais a habilidade é desenvolvida, maior é a capacidade de realizar repetições...” (SENNETT, 2009, p. 37-38).

Esse processo de copiar movimentos pode parecer ser algo apenas externo, de fora para dentro, mas se dá pelo mental e corporal. Segundo o neurocientista francês Alain 
Berthoz, o sistema que realiza o movimento corporal está intrinsecamente ligado ao dispositivo de percepção, não podendo ser dissociado um do outro, "a percepção não é apenas uma interpretação das mensagens sensoriais: ela é forçada pela ação, é simulação interna da ação, é julgamento e tomada de decisão, é emancipação das consequências da ação" (BERTHOZ, 2009, p. 15). Nosso processo de percepção depende de uma simulação interna da ação percebida, “percepção é uma ação simulada” (BERTHOZ, 2009, p. 15).

Assim, o processo para realizar ações corporais "exige um repertório de percepções relacionadas com o repertório de ações de cada indivíduo" (BERTHOZ, 2009. p. 22); para que a ação gestual aconteça e seja repetida com facilidade, é preciso construir uma simulação mental para o conjunto do repertório motor e do repertório sensorial de ações conhecidas.

Essa construção se dá pela observação e a repetição desta ação diversas vezes na prática, com o corpo e a mente engajados neste processo de aprendizado. Para aprender a copiar um movimento estamos com todos os sistemas cognitivos focados nesta função, um trabalho que exige tanto o mental como o físico.

Vamos criar aqui uma diferenciação entre repetir e reproduzir, chamaremos de repetição quando não há interpretação do agente da ação e reprodução quando este coloca a sua dinâmica deixando a sua personalidade realizar pequenas modificações na execução de uma ação ou movimento, assim a repetição será copiar movimentos externos a nós e a reprodução, realizar esses movimentos “copiados" de nossa memória.

Mas o que acontece depois que construímos essa simulação mental e ganhamos a preparação física para realizá-las?

Normalmente a reprodução das ações cotidianas e repetitivas se tornam "automáticas" após algum tempo de repetição, começamos a realizar sem a necessidade de prestar a atenção no que está se fazendo, chegando até o momento que não será mais preciso pensar/observar os movimentos para conseguir realizá-los, Sennett chama esse conhecimento de conhecimento tácito, 'Quando falamos em fazer algo 'instintivamente' muitas vezes estamos nos referindo a comportamentos que de tal maneira entraram em nossa rotina que não mais precisamos pensar a respeito." (SENNET, 2009, p. 62).

Neste momento encontramos o nosso primeiro problema, o conhecimento tácito, no que concerne as habilidades cotidianas será extremamente útil em nossas vidas, como dirigir e escovar os dentes, a automação para a reprodução das tarefas repetitivas nos permite a ganhar tempo e gastar menos energia na sua execução, mas quando passamos para as habilidades artísticas que como qualquer outra habilidade, "é uma prática decorrente de treinamento" 
(SENNETT, 2009, p. 64); isso pode ser um problema tanto para o processo de repetição dentro do treinamento para adquirir essa nova habilidade como para o processo de reprodução/expressão com essa nova habilidade.

Diferente de práticas esportivas e/ou cotidianas, as habilidades artísticas buscam evitar os movimentos autômatos, procurando a "organicidade" que é resultado do alinhamento entre corpo e mente na mesma ação. Isso acontece com o envolvimento do executor com o que está se fazendo, se manter "presente" é estar em um estado especial de atenção, um dispositivo mais complexo que apenas estar concentrado que envolve nosso sistema de percepção, memória, repertório motor e inclusive a criatividade:

Para mim, a atenção não é apenas um mecanismo relacionado com a percepção, como um comandante-chefe que decidirá onde e em que se preste a atenção; percepção é um mecanismo de antecipação de que se prepara para a ação, um mecanismo que define o mundo por nossas ações e intenções, cujos vestígios encontramos a em todos os níveis de nosso sistema nervoso, do mais elementar aos níveis cognitivos mais elevados. A atenção é não só a percepção consciente de estímulos reais e pequenas percepções, atenção pode usar imaginação. (BERTHOZ, 2009, p. 57.)

Desta forma, como podemos realizar as repetições de forma potente para o ator/mímico?

A repetição é necessária para o desenvolvimento de qualquer habilidade, Sennett apresenta um calculo aproximado: "o tempo necessário para alguém se torne um especialista costuma ser estimado em 10 mil horas" (SENNETT, 2009, p. 193). Então dentro de uma prática que demanda grande tempo repetindo algo, como fazer para que esta não se torne uma ação "automática", sem a "organicidade" proveniente da atenção do executor quando os movimentos começam a ficar mais fáceis de serem realizados e não é mais necessário "pensar sobre o que se está fazendo"?

Sobre essa questão, estudamos esse princípio em sala de aula através da observação e dos depoimentos dos praticantes sobre a realização contínua dos exercícios. Quando os praticantes começaram a compreender passo a passos a repetição dos exercícios, mesmo ainda sem dominar a prática por completo, eles relatavam que tinham dificuldade em manter a concentração, se desassociando da ação e observando suas mentes pensando em outras coisas alheias ao que se estava fazendo na sala de ensaio. 
Vamos definir como "estar presente" quando quem realiza a ação está com a atenção externa, os processos mentais e motores engajados na mesma ação. Chamei no plural: "os processos mentais" pois, seguindo a indicação de Berthoz, a atenção externa de estar presente não é apenas receber os estímulos sensoriais e estar consciente deles no momento, é um processo mais complexo. O cérebro, além de trabalhar com os estímulos sensoriais, o repertório motor de ações e a criatividade, está constantemente tentando "prever as ações futuras" com o uso de nossas memórias que, segundo o autor, são o combustível desse processo: “...memoria é um mecanismo que permite prever o futuro. o cérebro estimulado usa a memória para implementar processos mentais de predição.” (BERTHOZ, 2009, p. 264).

Esse princípio de predição de futuro proposto por Berthoz é uma construção biológica pela seleção natural da evolução do cérebro para a sobrevivência da espécie, "o cérebro é um simulador biológico que prevê extraindo da memória e realizando suposições." (BERTHOZ, 2009, p 5) Prever os próximos movimentos nos dá uma vantagem na defesa contra predadores e/ou para conseguir capturar presas para se alimentar. Para que esse dispositivo funcione, o cérebro precisa criar um "modelo virtual" de realidade onde será processada as informações baseadas em nossa memória e assim propor as futuras ações do objeto que observamos. Segundo Berthoz fazemos isso sempre que observamos qualquer movimento, isto é, estamos sempre num constante processo de predição de movimento. Para que esse sistema aconteça, a percepção precisa ser encarada como a base principal da cognição e, por isso, ele propõe a existência do "sentido de movimento" (mesmo afirmando que é contraproducente "dividir" os sentidos, pois o cérebro nos processos mentais não divide os estímulos/memória em sentidos). Esse princípio cria uma reação dinâmica entre a percepção e a memória, dentro desse complexo emulador que é o cérebro.

Assim concluímos que processos de aprendizagem de novas habilidades corporais, além de precisar de muitas horas de repetição da mesma prática, também precisam ser acompanhados de um estudo de como realizá-las de forma a não transformar uma prática expressiva numa ginástica fria. Mantendo a repetição como uma exploração através da manutenção da presença (concentração) do praticante, mesmo quando este começa a dominar os exercícios, fazendo-os sem dificuldades físicas ou de memorização.

Fizemos na parte prática, experimentações sobre rotinas para conseguir atingir esse objetivo, realizar a prática de repetição sem cair em ações frias e tornar esse treinamento uma repetição dinâmica, em que descrevemos as estratégias para manter a concentração dessa prática tornando-a potente em sua realização. 


\section{CAPÍTULO III}

\subsection{Sobre o Mimo Corpóreo}

Nessa sessão proponho uma escrita descritiva da minha pesquisa sobre o Mimo Corpóreo da maneira que organizo e nomino os elementos da técnica. Mesmo sabendo da dificuldade em descrever exercícios físicos e o risco de não fazer jus a sua complexidade e beleza prática, resolvemos criar esta referência de escrita como forma de fomentar o diálogo com aqueles que já pesquisam essa linguagem e buscam a sua própria forma de organização, como também para aqueles que desconhecem essa técnica possam compreender um pouco melhor esta pesquisa, visualizando a sua complexidade e vislumbrar possíveis aplicações.

Em nenhum momento esperamos que a descrição a seguir substitua a prática e muito menos que seja usada como uma espécie de manual para o treinamento sem um instrutor habilitado, reiterando o discurso anterior, essa organização escrita é uma forma de compreender melhor a técnica propondo a sua organização metodológica, sem querer propor algo definitivo, mas dar um pontapé inicial a uma possível organização e documentação da prática mais detalhada.

A seguir vamos descrever as bases do treinamento, dando um enfoque mais detalhado nas partes que acreditamos que possam ter suas descrições compreendidas mais claramente sem a demonstração prática. Algumas categorias serão apenas nomeadas sem muitas explicações detalhadas, pois são exercícios complexos em demasia para serem descritos verbalmente sem a demonstração, essa tentativa poderia se tornar algo completamente sem sentido.

Optamos por traduzir todos os termos para língua portuguesa, alguns termos eram originalmente em francês outros em inglês e alguns tinham diferentes nomes de inclusive significados distintos. Por essa razão propomos uma grafia em português, a mesma que utilizamos na prática nos últimos anos de pesquisa.

Todas as categorias listadas possuem uma série de exercícios e práticas para seu treinamento, esses não serão contemplados aqui, optamos por apenas listar as categorias sem colocar os exercícios usados para sua capacitação, pois além de ser algo extremamente complexo de se fazer, necessitaria de um estudo exclusivo apenas para a essa realização, que não é o objetivo principal deste trabalho. 
Vamos dividir a técnica nas seguintes categorias:

1. Articulações; 2. Dinamoritmo; 3. Contrapesos; 4. Estados de representação; 5. Exercícios plásticos; 6. Composição.

(*) No DVD em anexo (MENU:Demonstrações-CEPECA) existe uma explicação sobre as articulações com pequenas demonstrações.

As bases do Mimo Corpóreo:

\section{Articulações}

Fazendo uma correlação direta com o estudo musical, onde se pode dividir o som em notas e cada uma a ser executada com um tempo e dinâmica diferentes com infinitas cominações dentro das regras de composições harmônicas, esse mesmo princípio será levado para o trabalho corporal. O próprio Decroux algumas vezes comparava o estudo de divisão corporal com a ideia de teclas de um piano, "deixe os atores agirem no que se diz a respeito de seu corpo como um pianista age com o teclado de seu piano" (DECROUX em: LEABHART, 2008, p. 72).

Conceito base de todo o trabalho, onde será dividido em escalas: Corpo; Espaço; Energia; e Ações.

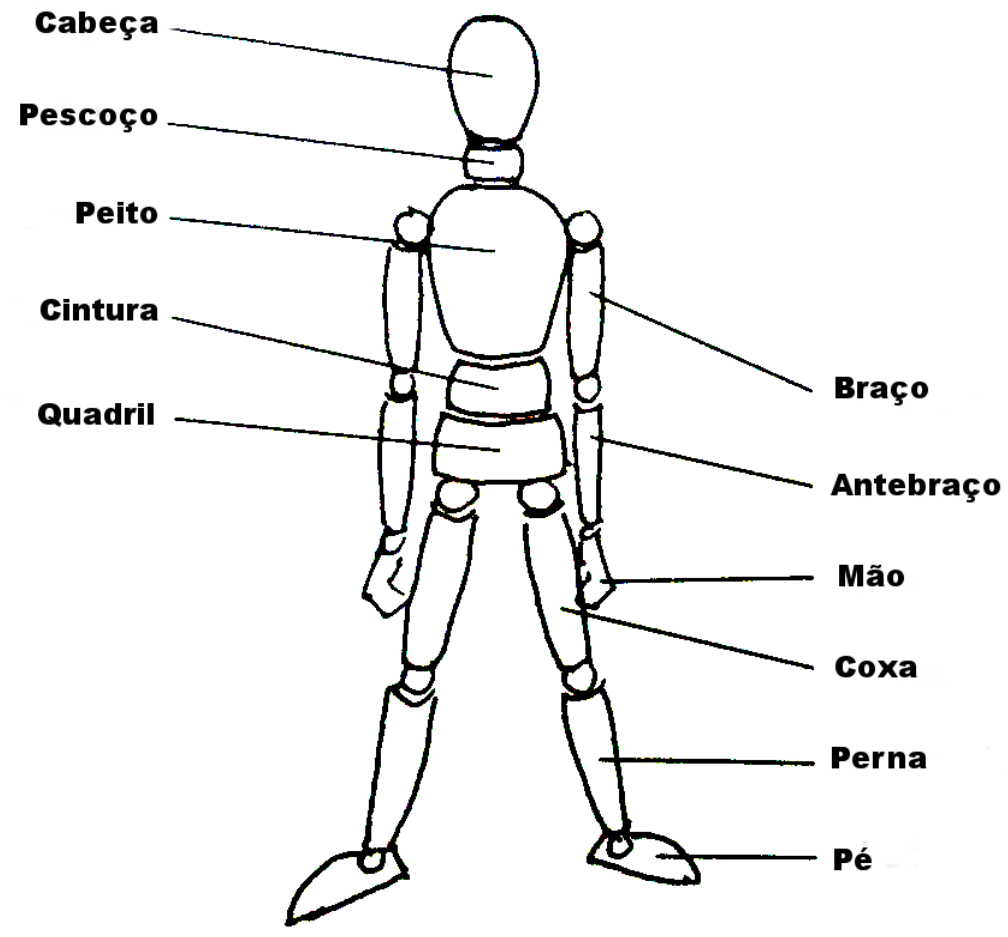

Figura 7 - Divisão Corporal. Fonte: (ANGER, 1998. p. 13) 
Tipos de articulação:

a) No Corpo: Divisão do tronco em diferentes blocos: cabeça, pescoço, peito, cintura, quadril e torre (corpo inteiro) ver figura 8 e 9.

Esse princípio é trabalhado tridimensionalmente, lateralidade, rotação e profundidade (frente e atrás, veja figura 10). Também é feita uma divisão dos braços, pernas, neste caso com uma divisão mais óbvia seguindo as articulações ósseas e das mãos com posições construídas (ver figura 11).

b) No espaço: Divisão vertical e longitudinal do espaço em torno do corpo em linhas de $45^{\circ}$ de distância entre si (oitavos). Ver figura 12

c) Na energia: Este estudo não tem parâmetros preestabelecidos inicialmente como os demais, mas consiste do mesmo princípio em dividir em escalas diferentes níveis do tônus muscular, entre o estado relaxado e o tenso.

d) Nas Ações: Esse é um princípio mais conceitual que físico, que consiste em olhar sobre a ideia de escalas as ações, decupando em partes de cada elemento em si e em conjunto com outras camadas, ex: isolar os movimentos de cada articulação de uma ação, e/ou dividir e estudar as suas camadas: movimento, dinamoritmo e as relações com outros objetos.
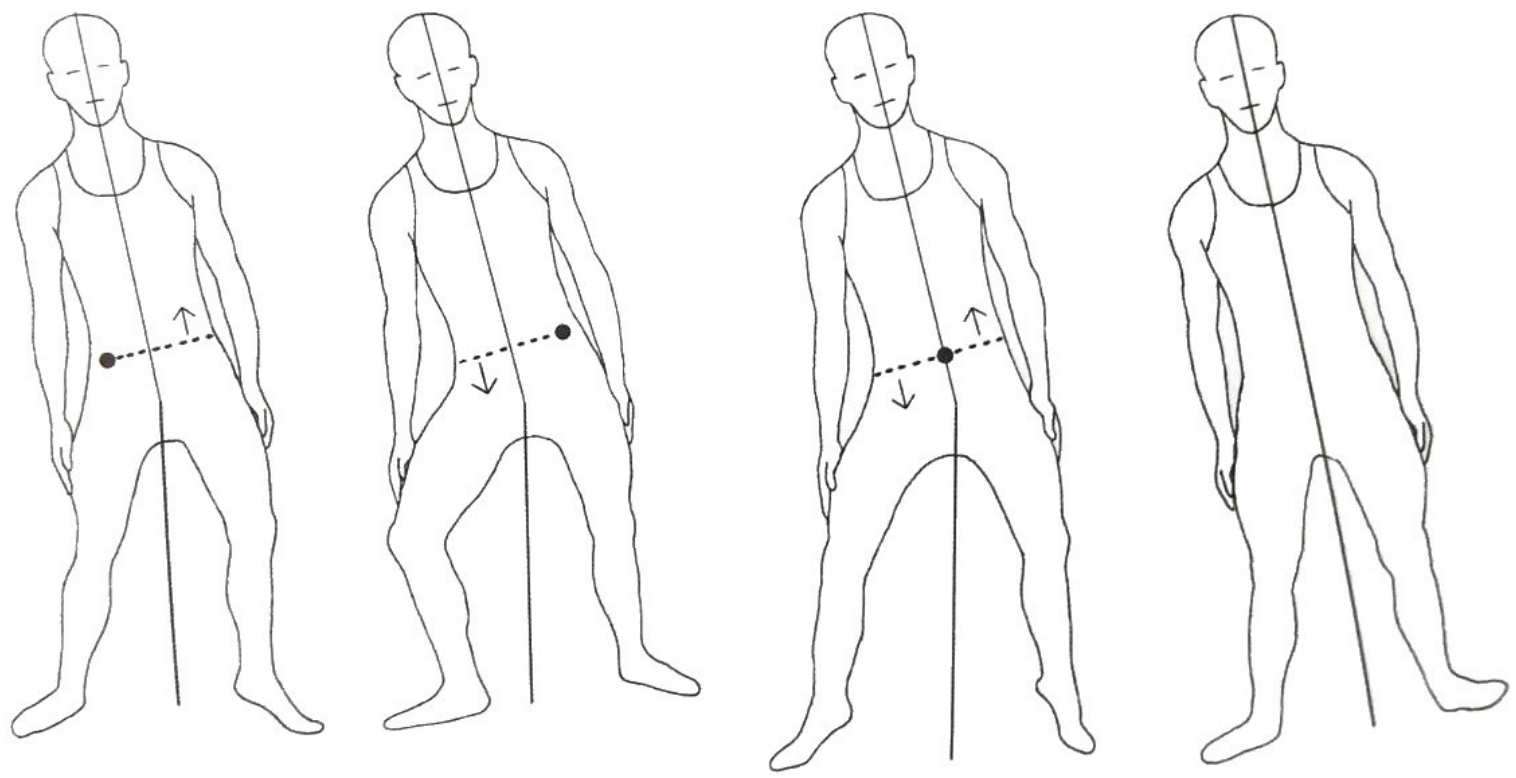

Figura 8 - Escala Lateral do corpo (quadril e torre). Fonte: (LEABHART, 2007, p. 118) 

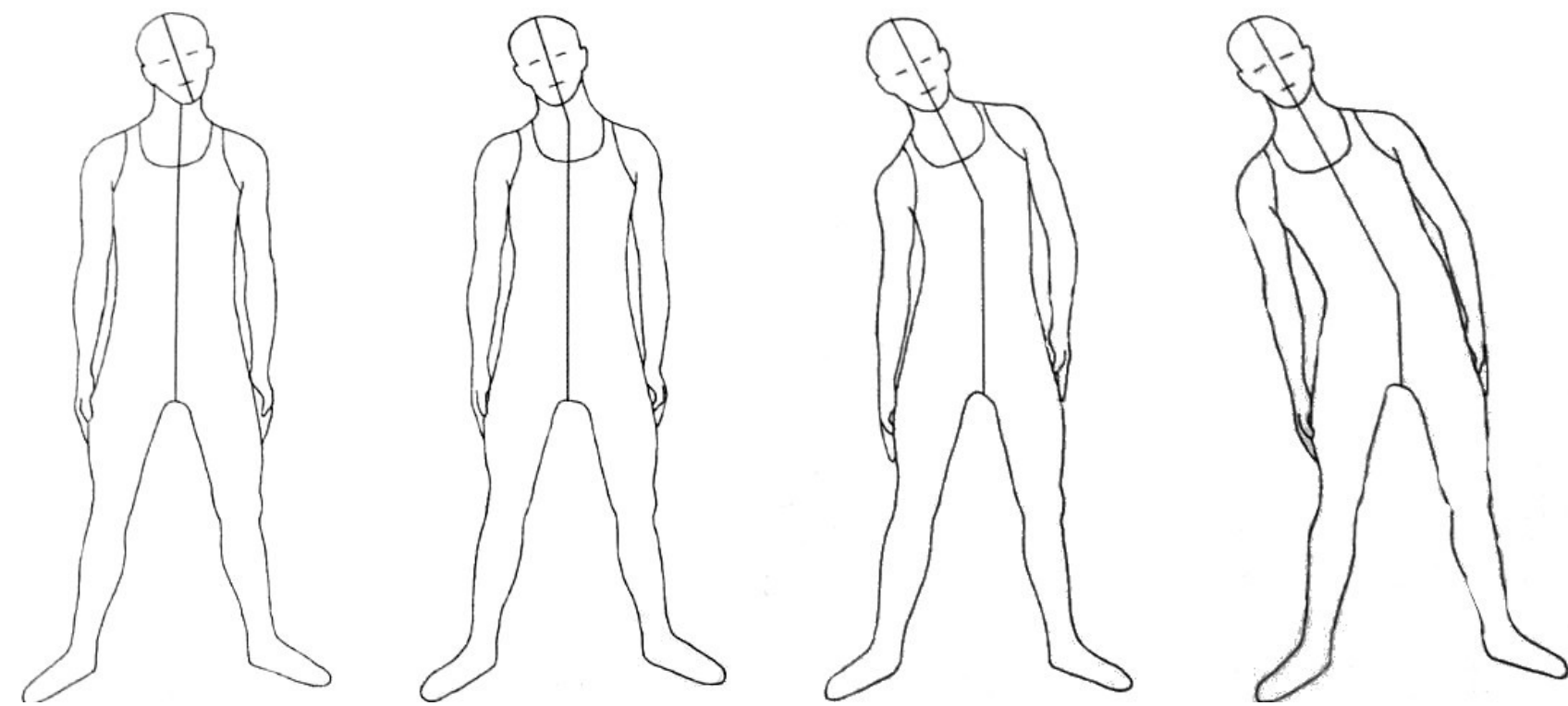

Figura 9 - Escala lateral do corpo (cabeça, pescoço, peito e cintura). Fonte: (LEABHART, 2007. p. 117)

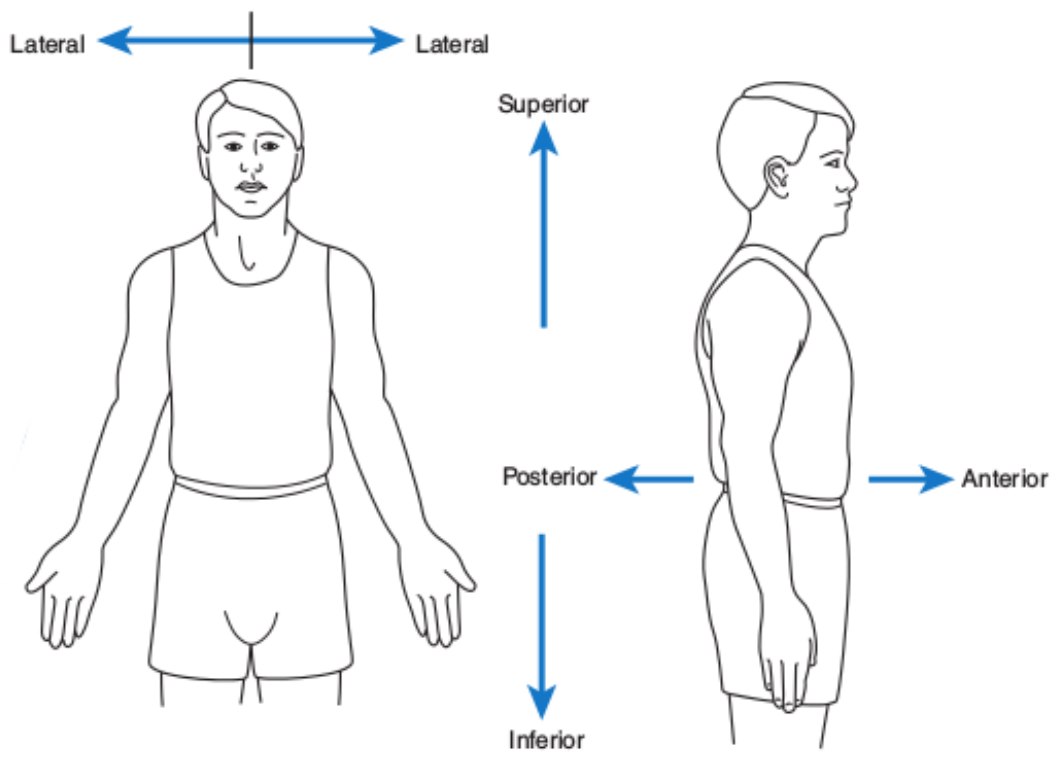

Figura 10 - corpo tridimensional. Fonte: (HAMIL, 2015, p. 11) 


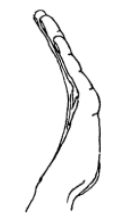

1

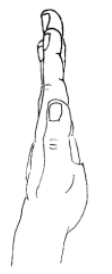

4

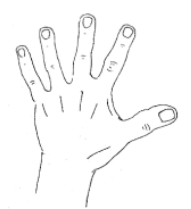

2

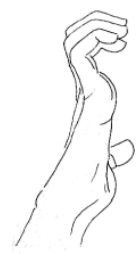

5
1 - Margarida

2 - Tridente

3- Concha

4 - Palheta

5 - Salamandra

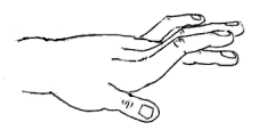

1

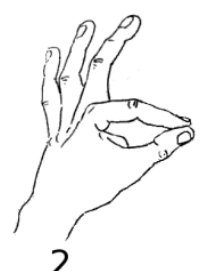

2

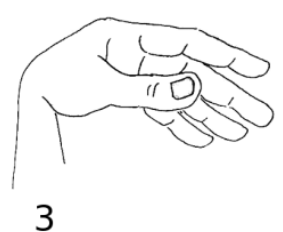

3
1 -Toque

2 - Pássaro

3 - Rabo de cavalo

Figura 11 - Posições das mãos. Fonte: (ANGER, 1998)

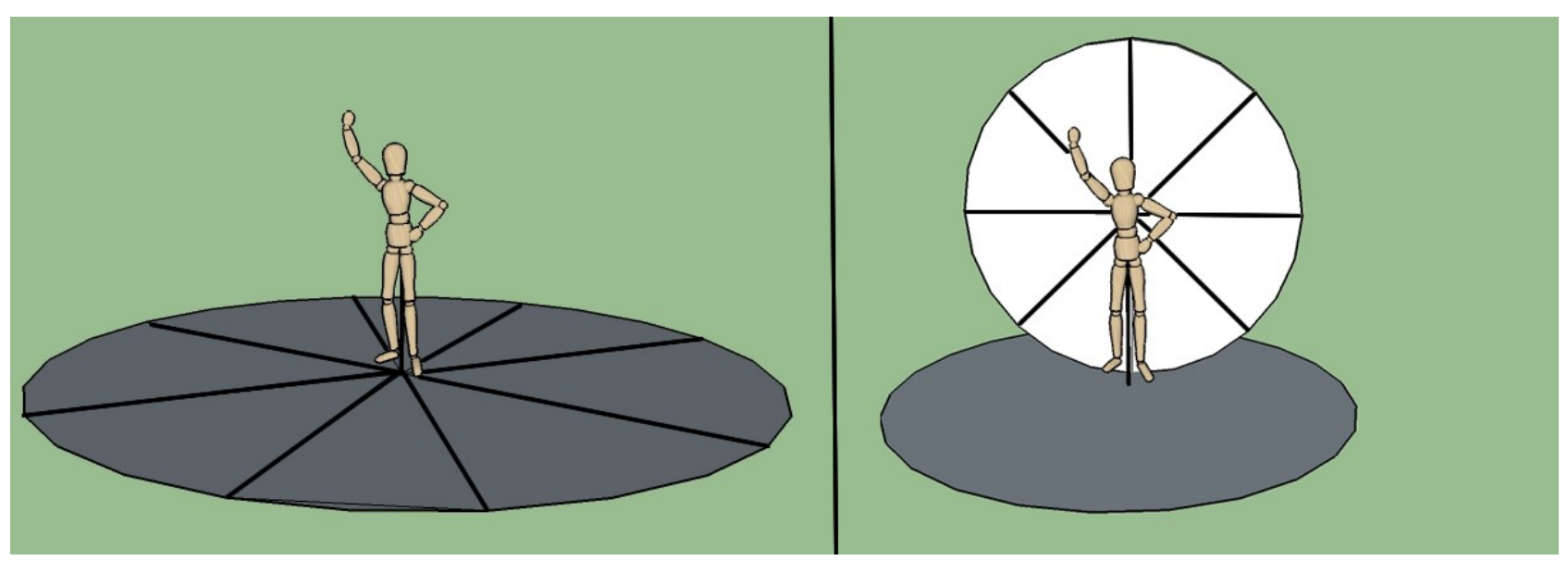

Figura 12 - oitavos no espaço, em dois planos. Fonte: arquivo do autor. 
Após definir as divisões dentro dessa ideia, existem princípios para o treinamento de várias combinações possíveis para o treinamento das articulações, essa base a seguir é prioritariamente para o corpo, mas algumas definições podem ser aplicadas de forma conceitual nas ações, as variações básicas são:

- Isolamento (staccato) - isolar o movimento de uma única parte da escala, movendo apenas esta parte sem mover as outras.

- Acumulativo - Mover parte por parte "acumulando" em grupos e movendo-os juntos, acrescentando parte-por-parte e as movendo em conjunto, como a metáfora de um trem em movimento com vários vagões aonde numa curva os vagões vão se alinhando um a um.

- Contradição - mover duas ou mais partes em direções distintas.

- Reestabelecimento - primeiro mover uma parte e depois alinhar todas as outras partes da articulação na posição da primeira que se mantêm fixa no espaço. Sempre terá uma parte fixa e as outras terão que se adaptar para se "encaixar" sob a parte fixa e reestabelecer uma linha reta com o corpo, o reestabelecimento sempre começa e termina em linha reta.

- Compensação - Uma parte do corpo "insiste" em ficar numa posição em relação com o espaço, outra parte abaixo (interligada) se move retirando ela da posição inicial, assim ela se move para retornar o ângulo anterior e compensar o deslocamento, essa lógica seguirá nos movimentos das partes seguintes que vão "compensando" para manter o ângulo inicial. A compensação pode ser realizada em diversos desenhos diferentes e também em direções diferentes da inicial, o importante é realizar esse "jogo" entre as articulações que vão se reorganizando para manter uma linha ou posição inicial, diferente do reestabelecimento, aqui nenhuma parte fica fixa no espaço e não precisa construir linhas retas aqui.

- Translação - "transportar" verticalmente uma parte no espaço. A translação no corpo vai trabalhar somente com a cabeça, peito e quadril. As partes "secundárias", pescoço, cintura e torre vão dar o suporte a translação. 
- Ondulação - realizar movimentos contínuos e proporcionais de várias partes em sequência para formar a ilusão de um "movimento de onda."

- Triplo e quádruplo desenho - combinação acumulativa de movimentos de vetores diferentes (lateral, rotação e profundidade) esse exercício pode ser realizado em conjunto com as variações acima. O quádruplo desenho é o deslocamento de um triplo desenho (a combinação acumulativa de lateral, rotação e profundidade) em translação.

\section{Dinamoritmo:}

Essa categoria é o estudo da complexidade do conjunto da dinâmica das ações, velocidade, intensidade, tônus, etc., o termo Dinamoritmo formado a partir de uma colocação de duas palavras, dinâmica e ritmo, "significa o coletivo de qualidades dos movimentos físicos, em toda a sua complexidade, que estão ligados a: seu contorno ou trajetória, a sua velocidade, o seu poder ou força.” (ALANIS, 2014, p. 10).

Dentro desse estudo que também é chamado por alguns de "a gramática do movimento", existem algumas categorias de estudo, os tocs, casualidades motoras e alguns outros dinamoritmos. Para realizar o treinamento dessa categoria, existem diversos exercícios dentro da prática que aqui não estão listados ou demonstrados, apenas está descrito as categorias.

Para a proposta de organização descritiva a seguir, partimos da referência de organização feita pela diretora e pesquisador Leela Alanis em sue artigo "The DynamoRhythm of Etienne Decroux and His Successors" na 24. ${ }^{\circ}$ edição do Mime Journal ${ }^{35}$, realizando uma tradução livre de algumas partes e acrescentamos algumas categorias e práticas de nossa pesquisa que não são encontradas no artigo original, também optamos por transcrever todas as nomenclaturas do francês para o português.

Tocs: Os tocs partem de exercícios práticas de qualidades predefinidas que podem ser aplicados em qualquer movimento ou ação, pontuando, realçando a intenção do gesto e/ou criando micro-narrativas.

35. http://scholarship.claremont.edu/mimejournal/vol24/iss1/2 
Podemos definir os tocs como contrações musculares que variam de intensidade desde a mais suave até uma mais explosiva, os tocs trabalham normalmente dentro de movimentos com percursos definidos, como agentes que modificam a qualidade desse movimento e/ou seu percurso. Normalmente, a mesma parte do corpo começa e termina o toc, que também pode acontecer como um movimento pequeno em staccato, agindo também como pontuações.

\section{Os tocs podem ser:}

Curtos: Tocs que servem como pontuação para algum movimento e/ou ação, necessariamente não precisam fazer parte desta ação/movimento, servem como pontuações ou como estímulo para seu início/fim.

Longos: Tocs que fazem parte de um movimento/ação, eles também podem servir para começar ou terminar algum movimento/ação, mas são parte essencial destes.

\section{Exemplos de toc curtos:}

Toc Simples (ou pontuação), é uma contração muscular de uma única parte do corpo com seu relaxamento em seguida como forma de pontuar, iniciar, terminar ou destacar uma ação, pode ser também realizado por um movimento staccato rápido de alguma parte do corpo isolado do resto. Também pode aparecer no meio de algum movimento causando uma suspensão na ação ou no deslocamento. Esse toc normalmente não interfere nas ações ou deslocamentos principais.

Este toc pode ser simples ou duplo (quando é repetido 2 vezes em sequência)

Toc Ressonância é quando o percurso de um movimento se inicia com um toc simples seguido de um movimento contínuo e mais lento que o toc, como se o percurso realizado em velocidade inferior ao toc fosse resultado deste. O toc ressonância pode ser toc simples e toc duplo (dois tocs antes de iniciar o movimento lento) e o toc pode ser interno ou externo, com o toc realizado como parte do percurso do movimento ou como outra parte do corpo, resultando do segundo movimento como reflexo dessa parte que se moveu. (pode ser feito toc duplo ressonância)

Toc Eletricidade, este toc é menos explosivo que os demais, tencionando a musculatura de forma mais contínua provocando um espasmo mais longo como se tivesse recebendo uma 
descarga elétrica, esse toque é utilizado normalmente como início de um movimento como se esse toc fosse uma resistência impedindo o movimento de iniciar.

Toc "Show Biz", este toc acontece no final do movimento e com as mãos, partindo de um movimento livre para uma pausa em staccato e tonificada. Esse toque consiste em deslocar a mão relaxada em movimento livre encerando o deslocamento numa pausa tonificada.

Toc Partida, vem como início de um movimento, como um sinal de partida. A diferença deste para o toc ressonância, é que depois desse toc não se precisa realizar o movimento como resultado dele, o movimento depois do toc não precisa ter uma dinâmica constante e pode ser seguido de um conjunto de movimentos.

Toc Parada, acontece quando um movimento tem uma "parada repentina", como se uma parte do corpo em movimento encontrasse um obstáculo e se torna impossível para que ele continue o seu curso. Como uma suspensão, não é o final do movimento, mas uma interrupção brusca em seu curso, a continuidade do movimento depois desse toc recebe uma mudança de velocidade e intensidade, tendendo a mais resistência e a desaceleração.

Toc Motor, acontece em uma parte específica, onde o corpo, ou uma parte do corpo se contrai muscularmente. Esta contração provocará um movimento ou deslocamento que enfrenta uma grande dose de resistência muscular que força a sua trajetória no espaço, com todo o corpo ou uma parte do corpo. O toc motor também pode ocorrer no final de um movimento como resultado de sua parada.

Toc Global, envolvendo todo o corpo, começando com uma total contração muscular ou implosão que faz com que o corpo todo se mova, ou alternativamente pode provocar o enceramento de um movimento de todo o corpo. O que diferencia um toque "Global" de um "Motor" é que o segundo pode iniciar ou terminar um movimento com uma parte (ou sequência de partes articuladas) do corpo ou com o corpo inteiro, enquanto o "Global" sempre vai implicar no envolvimento de todo o corpo e não precisa apresentar resistência durante deslocamentos posteriores a esse toc.

Toc Retorno, quando uma parte do corpo avança numa velocidade constante e de repente dentro do percurso do movimento, como um espasmo, recua de forma acelerada e rápida retornando a velocidade anterior na direção contrária, como se saísse em retirada ao encontrar algo "desagradável". Este toc também é chamado de "antenas de caracol", pois faz alusão a 
qualidade do movimento de suas antenas quando encontram um obstáculo.

Toc Luz, a ideia deste toc é ser mais suave que os outros, pode ser quase imperceptível, iniciando ou terminando um movimento ou acontecer como uma leve suspensão no meio de um percurso de um movimento. Este não apresenta praticamente nenhuma resistência.

\section{Exemplos de toc longos:}

Esses são tocs de ação mais longa, diferentes da categoria anterior, eles podem acontecer durante todo o percurso do movimento. Eles também podem aparecer como partes longas de ações e movimentos mais complexos, sem necessariamente provocar mudanças nos movimentos anteriores e posteriores servindo como destaque de partes ou como qualidade desta ação. Podem ser (e normalmente são) usados em conjunto de outros toques curtos, como ideia de consequência desses tocs. Eles podem acontecer no início, durante ou no final de outros movimentos/ações. São eles:

a) Derreter - como o próprio nome já diz, cria uma ilusão de "derretimento" de uma ação ou movimento/percurso, dando a ideia que este se desmancha no ar. Esse toc pode apenas retardar o movimento/ação principal que depois retorna a sua origem, pode terminar por completo a ação ou dar origem a outra ação conectada a primeira, dilatando a velocidade e os movimentos, o "derreter" normalmente acontece sem demonstrar resistência. No caso de demonstrar forte resistência, passa a ser chamado de "gravador".

b) Brusco - identifica uma sucessão brusca de pausas ou suspensões repetidas durante o percurso de um movimento sem apresentar necessariamente regularidade nas paradas, como se algo atrapalhasse o deslocamento, o tornando irregular.

c) Vibração - Trata-se de uma demonstração de esforço numa luta muscular para realizar um movimento, a vibração acontece por uma "resistência imaginária" mas visível em se mover, esse toc é realizado apenas pelas extremidades do corpo que se movem com dificuldade e esforço.

d) Mecânico - Esse toc acontece no início e no término de um movimento com um percurso pré-definido, para realizar esse toc, primeiro se recua na direção oposta para onde se quer avançar e finalmente avança em velocidade constante, e para encerrar o percurso se usa a 
mesma estratégia ao reverso, avança para depois do ponto do final do percurso para recuar até o ponto final de parada.

Esse toc dá a impressão de movimentos mecânicos se aproximando da qualidade de movimentação de sistemas hidráulicos.

\section{Sistemas de casualidades:}

\section{Sistemas de causalidades - Choque-Ressonância - Consequências}

Os sistemas de causalidades e um estudo dentro da ideia ação-consequência, implicando dois ou mais movimentos que estão conectados por uma relação causal, existe um movimento inicial que dependendo de sua dinâmica poderá causar um ou uma sequencia de movimentos também com dinâmicas distintas. Existe uma relação intrínseca entre o primeiro movimento e os seguintes, essa ação pode ser feita com partes distintas do corpo, com corpos distintos ou com a relação corpo-objeto.

\section{Algumas dessas categorias:}

a) Casualidade em Nuvem - Movimentos lentos e dilatados, um movimento numa parte do corpo provoca outro movimento em outra parte com a mesma dinâmica sem necessariamente ter terminado de se mover. (pode acontecer durante seu trajeto ou no final como consequência posterior)

b) Casualidade em Mola - Um movimento que encontra resistência crescente até o seu final, provocando um movimento contrário com uma força e velocidade maior, seguindo a ideia de alguém que pressiona uma mola e depois se vê empurrado de volta por sua força.

c) Casualidade em Espiralado - Um movimento rápido e intenso que gera uma sequência de movimentos com dinâmicas e direções diversas.

d) A causalidade em Corda - A causalidade em corda representa a conexão imaginária entre duas partes do corpo, supondo uma corda imaginária unindo as duas. Quando a primeira parte se move para longe da segunda a corda se estica trazendo com um pequeno atraso e com uma saída brusca a segunda parte, se move puxada pela corda imaginária esticada. 
e) A causalidade em Bastão - $\mathrm{Na}$ Causalidade em bastão é preciso imaginar duas partes conectadas por um bastão sólido, quando uma dessas partes inicia o movimento, a segunda parte é empurrada e imediatamente se move acompanhando a primeira.

f) Casualidade em Gaze - Um movimento muito suave que surge como resultado de um movimento rápido e brusco.

g) O Rebocador - Fazendo referência a um barco rebocador, essa casualidade descreve um movimento de duas ou mais partes conectadas, aonde a primeira irá se mover e carregar as seguintes que oferecem certa resistência, mas terminam se alinhando a direção da primeira, acompanhando a sua velocidade.

h) Olho Elétrico - Esta casualidade representa a ação e reação de duas partes que não estão conectadas fisicamente no corpo. A reação se dá pela ideia de uma parte querer "copiar" a outra buscando repetir o movimento ou a qualidade deste movimento com um pequeno atraso que é o tempo de uma parte "escutar" a outra e agir. Essa casualidade pode ser também ser feita com movimentos distintos e sem relação de direção e velocidade, representando o diálogo de duas partes desconectadas fisicamente, mas conectadas pelo olhar.

i) Efeito Teia de aranha - Um movimento de uma parte do corpo que começa muito lento de forma quase imperceptível, provoca o movimento de outras partes com as quais está conectado. Provocando um efeito de quase reverberação o primeiro movimento provoca a movimentação de outras partes sem necessariamente indicar a sua dinâmica, velocidade ou direção.

j) Efeito de Barco - Esta casualidade faz uma metáfora com o movimento de um barco que empurrado sobre a água desliza na direção da força que recebe. Significa um movimento de uma parte do corpo que tem uma velocidade constante sem encontrar resistência, como resultado de um impulso de uma dinâmica igual ou distinta.

k) Causalidade Hidráulica - Essa casualidade é quando acontece uma relação simétrica em duas partes de um mesmo corpo, que conectadas diretamente ou não, agem em sequência com 
movimentos quase mecânicos (com final e início claros, isolados do resto do corpo e com pequenas pausas entre as ações), seguindo a lógica de causa-efeito, um movimento vai gerar a força para o segundo, que acontecem em sequência.

l) Efeito Obstáculo - O efeito acontece quando uma parte do corpo é impedida de se mover como se encontrasse um obstáculo que não pode ultrapassar, e como consequência, outras partes assumem o movimento que estava sendo realizado com a mesma dinâmica e continuam o movimento.

\section{Outros dinamoritimos:}

Partida imperceptível - Como o nome indica, a partida imperceptível é um movimento que começa muito lentamente e sem nenhum acento em sua execução. Essa partida dará sequencia a uma movimentação com velocidade e tônus distintos de seu início.

Partida brusca ou Colapso - A partida brusca acontece acelerando e aumentando o tônus na parte inicial de uma ação destacando esse começo para voltar a velocidade normal, destacando seu início como se precisasse de um impulso extra para começar a se mover. A partida brusca em colapso é quando acontece "uma preparação" para esta partida, na forma de um relaxamento anterior ou movimento no sentido contrário de onde a partida vai acontecer.

Parada em Atitude - Atitude designa uma parada em suspensão, onde a energia do ator continua em movimento pela sua intenção, o movimento para, mas a intenção do movimento continua.

Mobilidade imóvel - Em qualquer movimento, podemos construir uma escala de resistência que vai de zero ao seu máximo que impede do movimento acontecer, esta é a imobilidade móvel, que é o movimento impedido por uma resistência maior que a sua força, mantendo o esforço na direção de realizar o movimento que não consegue acontecer.

Imobilidade transportada - Dividindo o corpo em parte inferior e superior (pernas e quadril x tronco) manter imóvel a parte superior do corpo e mover apenas a parte inferior sem que isso modifique a posição da parte superior, transportando-a pelo espaço. Uma parte em 
movimento e outra imóvel.

Raccourci - é um termo provavelmente "emprestado" do balé que significa encurtar, e está relacionado aqui com o princípio de condensar de uma ideia, tempo e espaço.

Pode ser realizado criando gestos ou ações curtos que sintetizam ações longas e complexas ou isolando um movimento dilatado de sua intenção, diminuindo o gesto, mas mantendo a força da intensão num gesto "encurtado", trazendo aqui o princípio de escalas.

Ponto Fixo - é manter uma parte do corpo "parada no espaço" enquanto o resto do corpo ou parte dele se move. O trabalho em torno do ponto fixo é algo comumente associado a Mímica pela criação e reprodução de objetos imaginários, concentrando a atenção no objeto que "não está lá", sendo ele representado pela imitação mimética. Esse recurso de construção de objetos ou apoios imaginários também pode ser usado na forma de suporte a outras criações que necessariamente não sigam essa característica estética.

O ponto fixo é uma ferramenta que vai além da imitação e reprodução do real, ele pode ser usado como recurso visual/coreográfico, metafórico para ações simbólicas (estar preso a uma ideia, por exemplo) ou para pontuar ações ou gestos.

O ponto fixo foi desenvolvido por Decroux no início de sua carreira pedagógica como parte do seu breve estudo sobre a ilusão, pesquisa abandonada para dar o seu foco no trabalho mais abstrato. $\mathrm{O}$ uso do ponto fixo nunca foi abandonado, mantido de forma mais tímida em suas criações artísticas, sem chamar o foco para si aparece em diversas peças e figuras compostas por Decroux.

\section{O ponto fixo pode ter duas relações:}

\section{- Em relação com o espaço:}

Alguma parte do corpo num local fixo no espaço, é a forma mais conhecida, para criar essa ilusão de manter uma parte do corpo parada no espaço é necessário sempre 2 ações (ou movimentos) a principal e a compensatória.

A principal é o que o público irá ver a compensatória é a ação que permite acontecer a ilusão, essas ações são dois movimentos realizados ao mesmo tempo e na mesma velocidade.

Exemplo: Segurar um objeto imaginário fixo no espaço e afastar o corpo deste objeto mantendo a mão segurando-o, a ação principal que todos irão ver é o corpo se afastando enquanto a ação que cria a ilusão e não será "percebida" é a de flexionar o braço na mesma 
velocidade na direção oposta do deslocamento do corpo, "compensando" o afastamento do corpo, mantendo a mão no mesmo lugar no espaço, criando a ilusão que ele está segurando algo. (Veja figura 13)

\section{- Em relação com objeto:}

Esse ponto fixo é para ser feito quase exclusivamente com as mãos, seguindo o mesmo princípio do anterior com a diferença de ter aqui dois pontos fixos um ao outro e não no espaço. Esses pontos têm que manter a distância e proporcionalidade entre si mesmo quando o corpo ou os membros se movem, para isso acontecer, é necessário realizar vários movimentos compensatórios, mantendo-se em mente que o que será percebido pelo público é a manutenção da distância e a proporção desses dois pontos.

Exemplo: segurar um bastão imaginário, as duas mãos têm que seguir a mesma proporção e distância como se tivessem segurando um bastão real, a posição e a distância entre as duas não pode alterar enquanto se movimenta o braço e o resto do corpo, para isso será necessário diversos movimentos compensatórios, que também não serão "percebidos” pelo espectador.
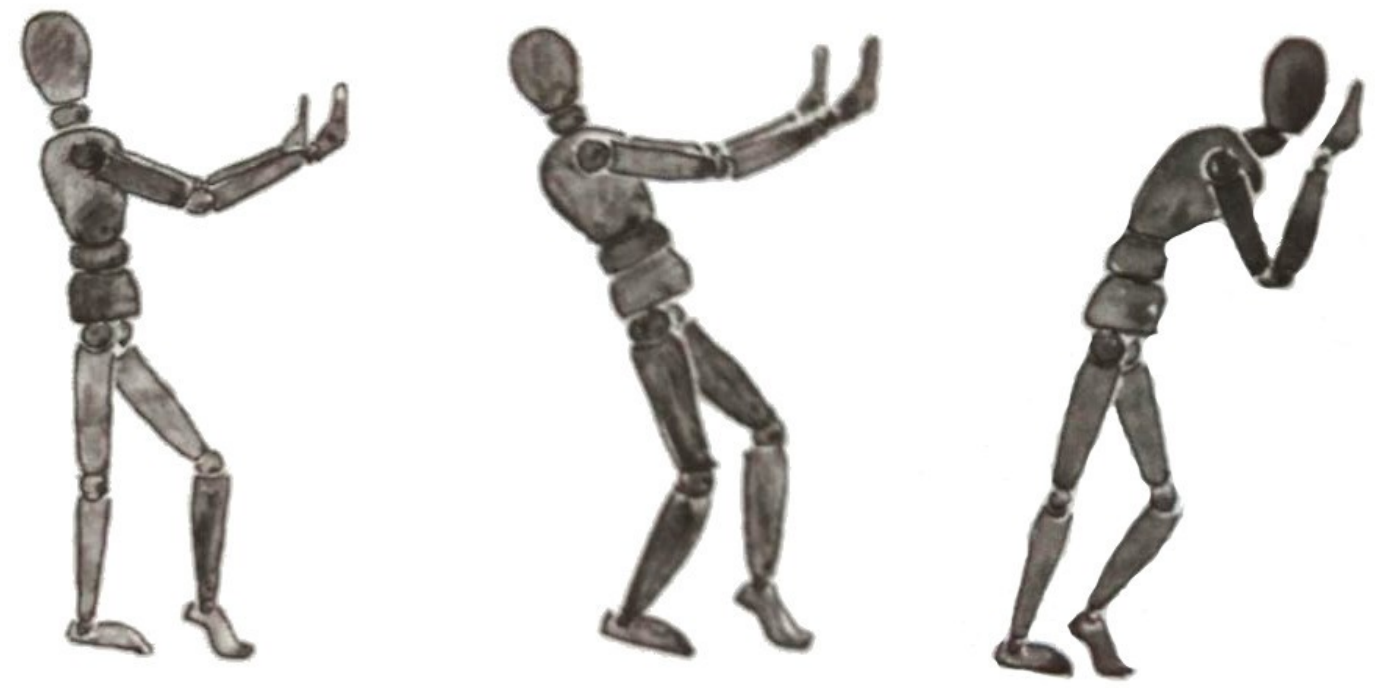

Figura 13 - Ponto fixo no espaço - Fonte: (ANGER, 1998. p. 62) 


\section{Contrapesos:}

Foi onde começou o estudo da Mímica, "foi com os contrapesos que eu comecei a estudar a mímica. Tudo tem peso." (DECROUX em LEABHART, 2008, p. 145), e consiste no estudo da relação com a força da gravidade, o peso do próprio corpo que se move e se relaciona com objetos leves e pesados a sua volta, partindo de dois princípios: puxar e empurrar. Começando por esses contrapesos, é feito uma série de exercícios que reproduzem no corpo as suas possíveis variações, pegar, carregar, levantar, receber, elevar, atirar, etc. Se relacionando com situações reais ou hipotéticas estudando os vetores do peso nas articulações e no deslocamento do corpo foram construídos uma série de exercícios que mesmo alguns sendo estilizados, realizam a biomecânica real do corpo na execução de tarefas e muscularmente simulam o esforço que seria da ação real.

Os contrapesos são a reprodução da mimese do esforço e não a mímica da ação, por exemplo, alguém que carrega um fardo pesado, o contrapeso desta ação não será demonstrar o fardo (o objeto) ou a relação com o objeto, mas reproduzir muscularmente a biomecânica do corpo no esforço de carregar esse objeto colocando o corpo na situação de esforço e muscularmente realizar esse "esforço imaginário".

Os contrapesos se dividem em algumas subcategorias: Contrapeso Escolar e Contrapeso Moral ${ }^{36}$ :

"Escolar"; podem ser "leves ou pesados", são os que lidam com objetos reais e normalmente estão ligados ao trabalho braçal/artesanal e o esporte. Exemplo: levantar um fardo, jogar um disco, empurrar um objeto pesado, costurar etc.

"Moral"; é a representação de "dramas internos", segundo Decroux, tudo tem peso, inclusive os pensamentos, nos contrapesos Morais, é colocado a mesma ideia de puxar e empurrar só que de forma metafórica de lidar com o peso dos sentimentos/pensamentos.

O estudo do contrapeso consiste no estudo e criação de "ilusões corporais" da relação com o peso, partindo de ações concretas, além desse trabalho de criação sobre a observação e reprodução do esforço, existem como parte do treinamento alguns exercícios estilizados que simulam algumas situações específicas, alguns desses são:

36. Também é chamado de "contrapesos profissionais”, alguns exercícios plásticos que lidam com a ideia do esforço e do peso, entre eles algumas "figuras de estilo" e o exercício do tensor. 


\section{- Supressão de suporte:}

Esse exercício consiste num "jogo" de tirar um dos suportes de apoio do corpo e deixar o corpo cair, "segurando" no meio da queda ou rapidamente reestabelecer o apoio de volta antes de começar a queda.

A partir de uma posição onde o equilíbrio está dividido entre as duas pernas de base, tira uma das pernas do chão, sem compensar o peso e o equilíbrio para o lado oposto com o resto do corpo que se mantém imóvel, podendo ceder a queda retornando a colocar o apoio antes de cair por completo e pressionar o chão até o corpo voltar para a posição inicial ou retornar rapidamente o apoio antes do corpo começa a cair.

\section{- Caindo sobre a cabeça:}

Esse exercício consiste em jogar o peso do corpo para empurrar algo pesado para baixo, sendo necessário usar o peso do corpo para deslocar esse objeto, "caindo sobe ele" começando o movimento pela cabeça e jogando o corpo todo (empurrando com os braços) "o peso do corpo se transporta de uma queda em horizontal para empurrar verticalmente com o eixo central na pélvis" (LEABHART, 2007. p. 80)

\section{- A Máquina:}

Esse contrapeso é inspirado no movimento de uma máquina rudimentar de desenredar lã, vista por Decroux no começo de sua vida adulta deixando a imagem gravada na sua memória (LEABHART, 2007, p. 80). Aqui o movimento é de levantar algo muito pesado que está no limite de nossa capacidade, por isso é necessário "vestir" o peso, ir para baixo desse objeto, trazê-lo para próximo ao corpo e levantar o corpo junto com o objeto o levantando de baixo para cima em linha reta, descendo em curva e subindo em linha reta.

\section{- Tesoura (sissonni):}

Esse contrapeso acontece no deslocamento do peso do corpo por um movimento de abrir e fechar, diferente do passo do balé esse deslocamento pode ser em horizontal ou vertical, e pode ser ou não relacionado ao transporte de peso (empurrar e puxar).

Ainda existem alguns exercícios de contrapesos estilizados a partir da observação de ações ligadas ao trabalho, esses contrapesos podem ser realizados juntos com os outros "maiores" e podem ser combinados entre si, alguns deles são: 
- Pistão: uma força aplicada numa linha reta em qualquer direção sob resistência, com o início e final do percurso definido e claro, esse esforço acontece somente durante o momento do percurso.

- Mola: igual ao pistão, apenas que no final do movimento ele é empurrado de volta.

- Tensor: com o vetor de força no inverso da mola, aqui a resistência está na ação de puxar algo que resiste e puxa de volta.

- Em obstáculo: consiste em realizar um movimento em curva para pegar algo (também empurrar ou puxar algo), esse desvio de rota é realizado para se esquivar de algum obstáculo que está na frente, tanto o movimento de ir como voltar tem que se relacionar com a ideia desse obstáculo.

\section{Estados de representação:}

Os estados de representação são categorias de estudo que lidam com diferentes qualidades preestabelecidas de movimentos e a sua realização, esse exercício era originalmente chamado de "categorias de representação" e resolvemos trabalhar como a terminologia "estados", pedindo aos atores que não apenas demonstrem com o corpo as categorias, mas que descubram seus processos internos relacionados com o que tem que demonstrar externamente, entrando nesses "estados" pela percepção da dinâmica corporal de cada categoria. Esse é um estudo que parte prioritariamente da relação do ator com peso (estar) e tempo (trajetória) em suas ações e seus gestos.

São elas:

- Homem no Esporte - Movimentos e ações onde o esforço corporal é aparente, o ator demonstra o esforço físico onde ele é necessário na ação. Essa categoria está relacionada principalmente ao esforço do trabalho e/ou ao esporte, se subdividindo em 3 subcategorias:

a) No Trabalho

Quando o ator se relaciona com o esforço do trabalho braçal, essa subcategoria também é chamada por algumas pessoas de "na aflição" ou "Na dor" pois é a demonstração do esforço pesado quando os músculos estão no limite de sua 
resistência, dentro de uma intensidade alta sem tempo para descanso. $\mathrm{O}$ corpo aqui se deforma pelo esforço contínuo se tornando a própria imagem do esforço realizado.

b) $\mathrm{Na}$ Arte

Os movimentos se referem também ao trabalho manual (artesania), mas de forma mais harmônica que o anterior, onde o esforço é intenso mas acontece uma preparação anterior ao movimento e é permitido níveis diferentes de tônus e pausas entre as ações.

c) No estilo

Ideia de demonstrar o trabalho corporal intenso com leveza e graça, onde os músculos trabalham sem grande esforço, essa subcategoria também é chamada de "na Ilha", pela ideia utópica de uma ilha onde seus fortes habitantes realizam seu trabalho braçal em harmonia

- Homem na Sociedade - Movimentos e ações onde o esforço não é aparente, o ator sublima a demonstração do esforço físico, mesmo que a ação seja algo muscularmente intenso de se realizar, o esforço não é demonstrado, essa categoria representa basicamente a ações que não precisam de esforço físico para a sua realização.

- Homem nos Sonhos - o ator lida com a quebra da realidade, mundo dos sonhos/imaginário, representando isso em seus movimentos como se o corpo fosse transportado para fora do mundo real. Essa categoria vai acontecer pela dilatação da relação do tempo e do espaço, podendo também alterar a relação entre peso e a gravidade. Essa alteração visa a criar esse estranhamento nos movimentos que não pertencem mais a lógica de um corpo lidando com o mundo real e suas relações de espaço. Essa categoria, diferente das outras anteriores, não lida com tipos de movimentos específicos que vão demonstrar o esforço ou não, mas "uma maneira de fazer, uma maneira de ofegar. Um movimento com certo ritmo, certa textura muscular que faz com que o corpo tenha um ar dilatado e não faz o retrato do momento presente." (SOUM, 2015, p. 22)

- Estatuário Móvel - É “a arte de mover o corpo” (LEABHART, 2007, p. 20), o ator constrói com o corpo e suas articulações em três dimensões, figuras/imagens que representam pensamentos/sensações, de forma não narrativa, levando a metáfora de uma estátua que se move lentamente e parte por parte. 


\section{Exercícios plásticos:}

Os exercícios plásticos são compostos de várias categorias que dialogam com todas as demais apresentadas anteriormente, seguindo o princípio de trabalhar a partir do corpo nãocotidiano, os exercícios plásticos são a extrema estilização do corpo e das ações.

As categorias que lidam com a dilatação do corpo-cotidiano:

\section{1) Peças:}

São peças coreográficas criadas originalmente por Decroux que aplicam os princípios da técnica em criações abstratas. Quase todas as peças estão relacionadas ao trabalho, a maioria em formato solo com algumas em duo e poucas em grupo.

\section{2) Figuras de estilo:}

Como as peças, apenas que mais curtas, as figuras são pequenos poemas corporais, e representam além da imagem do trabalho, se relacionando com as artes plásticas e literatura. Existem figuras fixas e em movimento, todas em formato de solo.

\section{3) Estudo de caminhadas:}

O estudo de caminhadas e marchas estilizadas pelo estudo de várias possibilidades de deslocamento.

As Marchas se dividem pelas 4 categorias pelos "estados de representação", caminhadas no esporte, na sociedade, nos sonhos e no estatuário móvel.

\section{4) Exercícios estilizados:}

São peças corporais curtas criadas sobre a estilização de ações comuns. Partindo desses objetivos simples (entregar, se despedir, etc.) se cria um percurso poético dilatado e articulado, aplicando todos os princípios da técnica, algumas delas são:

- $\mathrm{O}$ ato de oferecer

- Atos de Politesse

- Despedidas

- Pegar e colocar

- Tensores

- Ato de designar

\section{Composição:}


A composição dentro do processo de treinamento do Mimo Corpóreo pode seguir dois princípios base, acontecendo primeiramente "dentro" e depois "fora” da técnica.

Dentro é a experimentação com os elementos no processo de aprendizado da própria técnica, realizando exercícios criativos e de composição com os elementos do treinamento intercalando-os entre si, repetindo movimentos e ressignificando-os pela intercalação dos exercícios na forma de estimular a sua compreensão, esse treinamento deve ser feito junto com o treinamento formal de repetição e serve como estímulo criativo para os praticantes se sentirem seguros para avançar a uma segunda fase de composição, quando a técnica já está com um nível maior de compreensão.

A aplicação fora da técnica é quando se utiliza o ganho do treinamento para a criação cênica, a limpeza dos gestos, precisão dos movimentos, isolamento de partes do corpo, níveis de tônus, etc. Esse viés de aplicação é livre de regras mais rígidas e vai ser formatada individualmente para cada processo, sempre buscando não repetir poses ou movimentos e/ou gestos utilizados dentro da prática, liberando o corpo do excesso de formalismo do treinamento.

Como o processo de treinamento do Mimo Corpóreo demanda uma quantidade elevada de repetições de um mesmo exercício e/ou posição, se torna uma tendência quase natural que o praticante ganhe um grande repertório de "gestos prontos" que podem virar material para a composição cênica num processo de colagem, por isso é importante manter uma prática de limpeza gestual, mantendo o ganho com o treinamento e eliminando os artificialismos que podem aparecer pela repetição regular de alguns exercícios.

Os métodos de composição são a composição direta e o improviso, a composição direta na primeira fase (dentro) é realizado através da proposta de intercalar diferentes exercícios, realizando eles de formas diferentes e experimentando aplicar outros princípios da técnica entre si.

O improviso parte de ações simples e não se utilizam de palavras para estimular os praticantes a aplicar a sua expressão corpórea, levando o ideal criado por Decroux de "no improviso o ator deve começar como um ator de cinema e terminar como um acrobata", o improviso pode ser em solo ou em grupo, usando ou não o véu. 


\subsection{O uso do véu no treinamento}

Um homem seminu, com um véu cobrindo o rosto, desenhando o espaço com o seu corpo sobre uma base instável, essa imagem icônica de Etienne Decroux ficou marcada no imaginário, definindo tanto o seu trabalho como representando a própria técnica, quando o assunto é a Mímica Corporal, essa é a primeira imagem que aparece, no lugar do símbolo escolhido por Decroux, o desenho de um cavalo-marinho. A força de sua própria imagem, seu corpo seminu com o rosto coberto por um véu ficou marcado no inconsciente.

Essa representação talvez exista tanto pela sua escolha de aplicar todo o corpo na criação cênica, como também uma forma de diferenciar seu trabalho do de seu aluno mais notável, Marcel Marceau que se utilizando dos ensinamentos de Decroux desenvolveu um trabalho baseado no resgate da pantomima clássica ${ }^{37}$, hoje, tanto sua personalidade como o seu trabalho ganharam tanta notoriedade que Marceau se tornou um sinônimo para mímica.

\footnotetext{
A ideia de uma arte dramática que se expresse pelo movimento do corpo e que possa abrigar sob o seu vasto teto, não somente aquilo que causa risos, mas também que desperte terror, pena e um sonho caminhante que ainda estava por ser encontrada. Agora ela foi encontrada. Eu já fui iniciado nesta prática pela escola da Vieux-Colombier.

O que eu inventei foi minha crença nesta arte.

Um dos exercícios nesta escola consistia em representar cenas curtas, muitas eram trágicas, com o rosto coberto e o corpo quase nu. (DECROUX, 1985, p.29)
}

Segundo Thomas Leabhart, foi Copeau que reintroduziu o uso de máscaras no mainstream do teatro ocidental, resgatando o "poder da máscara" que tinha sido esquecido após a morte da commedia dell'arte na Europa, poder de pelo corpo com o uso das máscaras, "restaurar a verdade física contra a atuação falsa" (LEABHART, 2007, p.48).

Usando as máscaras inexpressivas como principal ferramenta em sua escola, chamando-as de máscaras nobres, Copeau buscava como função primaria que o ator se conectasse a "algo maior do que a figura de si próprio" (FREIXE, 2014, p.61) propiciada pela alteração da consciência do praticante com o uso da máscara, mudando a sua relação com a cena, "transformando o palco vazio através de sua presença, não primariamente através da literatura, música, figurinos ou cenografia" (LEABHART, 2007, p.51), essa busca de Copeau se tornou o princípio do trabalho de Decroux, que nomeou o seu trabalho de Mímica

37. Inspirada na "Pantomima-de-cara-branca" do século dezenove, que tem como origem a imagem do Pierrô vindo da commedia dell'arte, onde se priorizavam os braços, mãos e o rosto com os artistas apresentando cenas mudas, normalmente cômicas. (LEABHART, 2007. p.32) 
Corporal, nome dado ao treinamento com máscaras na escola e durante toda sua carreira sempre atribuiu a criação de sua técnica ao seu antigo professor.

Depois de reabrir sua escola em Paris em 1962, Decroux gradualmente perde o interesse em realizar demonstrações públicas ou criar mais espetáculos se concentrando apenas na pesquisa e no ensino. Na mesma ocasião deixa de usar em sua prática, o véu (e qualquer tipo de máscara), chegando a afirmar que o seu uso "chamava tanta atenção como um rosto expressivo" (LEABHART, 2007, p. 57), propondo no lugar manter um rosto inexpressivo e translúcido, "que, evitando trejeitos, se modifica como as nuvens se movendo lentamente no céu" (LEABHART, 2007, p. 57).

(...) sentado quieto entre os expectadores eu presenciei um espetáculo fabuloso.

Consistia em mímica e sons. Toda a performance aconteceu sem uma palavra sem maquiagem sem figurinos sem nenhum efeito de iluminação, sem cenários e nenhum outro acessório.

Os atores eram tão habilidosos que conseguiram condensar várias horas em alguns segundos e conseguiram agregar vários locais em apenas um. Simultaneamente sobre nossos olhos eles tiveram num campo de batalha, na vida ordinária no mar e na cidade.

Os personagens alternavam de um para outro com total veracidade.

A atuação foi emocionante e foi compreendida por uma beleza plástica e musical. (DECROUX, 1985, p. 4-5, tradução nossa)

Decroux não deixou grandes indicações sobre o uso pedagógico do véu e da máscara em seu treinamento, em seus poucos relatos e escritos sobre o assunto ele aborda mais a questão conceitual e estética da máscara do que elementos que remetam a aplicação no processo de ensino e treinamento.

Entrevistando alguns ex-alunos de Decroux sobre esse assunto, perguntando sobre o uso do véu no treinamento, Yves Lebreton afirma que, "durante o período que esteve na escola em Paris (1964-1968) nunca teve contato com o uso de máscaras ou véus durante as aulas e treinamentos" ${ }^{\prime 3}$ e Thomas Leabhart, conta que usou máscaras em algumas demonstrações públicas "a pedido de Decroux, e sem nunca receber indicações sobre seu uso" 39 .

Algo ainda pouco discutido, o uso do véu dentro do treinamento e formação do Mimo Corpóreo faz parte do imaginário sobre o trabalho e a técnica de Decroux, e ainda é utilizado por algumas escolas como parte do treinamento pelo princípio de velar o rosto e revelar o

38. (LEBRETON, 2013) Entrevista realizada com Yves Lebreton pelo autor.

39. (LEABHART, 2011) Entrevista realizada com Thomas Leabhart pelo autor. 
corpo que "desprovido da expressão facial, fica à disposição do intérprete o restante do seu corpo." (MASCARENHAS, 2010)

O véu elimina a expressão facial e, portanto, permite a expressão de necessidades, desejos, emoções e pensamentos através apenas dos movimentos do corpo (Decroux, p9. 2001). Decroux comenta que é uma ação preguiçosa para um ator o uso de máscara de um personagem, isso simplificaria a sua tarefa ao ponto de que só serão percebidas quaisquer características que sejam incorporadas pela máscara (Decroux, p148, 2007).

Um ator "sem rosto" pode representar todos os tipos de personagens com a seu corpo (DECROUX, p. 30, 1978), e a grande vantagem de uma máscara neutra é que ela permite ao ator interpretar todas as possíveis emoções "sem parecer ridículo" e no processo tornar o corpo um "rosto simbólico", representando tudo o que precise ser retratado (Decroux, p. 148, 2007).

Como a obra artística de Decroux caminhava em direção a criações mais abstratas, ele experimentou diferentes tipos de mascaramentos, eventualmente preferindo o véu, "que consistia em colocar um tecido translúcido esticado sobre o rosto e o queixo, revelando apenas o contorno das características do rosto" (FELNER, 1985, p. 61).

Segundo a observação de Felner sobre uma das peças abstratas de Decroux, chamada As árvores, "aqui o véu serve para misturar o rosto com o corpo; camuflar a cabeça persistentemente humana, sem tirar a atenção da ação, e permitindo que a totalidade corpo se torne uma metáfora de uma árvore" (FELNER, 1985, p. 62).

O véu nesta peça expande o conceito de máscara para um mascaramento do corpo, eliminando o rosto o trabalho corporal se torna uma máscara representando uma árvore, "o corpo-máscara do ator permite uma nova relação ator/personagem como um entrelaçamento entre sujeito e objeto, entre o eu e as coisas que o atravessam" (STELZER, 2009)

Meu primeiro contato com o uso do véu foi durante a minha formação pela antiga escola International School of Corporeal Mime em Londres, onde esse recurso era utilizado apenas como suporte para o treino do repertório e alguns exercícios de improviso algo reservado apenas para alunos avançados. A única indicação recebida para o seu uso neste período era de buscar destacar a expressão do corpo eliminando o rosto.

Essa experiência despertou meu interesse sobre estudar o uso do véu dentro do processo pedagógico do Mimo Corpóreo, pois acredito que esse elemento é de grande potência e tem muito a colaborar em processos de ensino e criação, e não por acaso se transformou praticamente na imagem icônica do legado de Decroux. 
Aplicamos o estudo em exercícios de improvisação e suporte em cenas prontas; não como objetivo final, mas sim como meio de descoberta de novas possibilidades expressivas aplicadas como estudo da plasticidade de um corpo extra-cotidiano.

Chamo o uso do véu na minha aplicação do Mimo Corpóreo de "anti-máscara"; no lugar de vestir uma máscara, colocando um elemento sobre o rosto com o qual o corpo deve se relacionar.

Utilizamos a metáfora inversa de retirar um elemento, neste caso o rosto do ator, e por esse processo o corpo se torna uma máscara, gerando um corpo fictício. Partimos sempre da primeira orientação de Decroux de "decapitar" o ator através da anulação de seu rosto, obrigando-o a passar da expressão de mãos e rosto a uma expressão global do corpo - "corpo máscara". Para o uso do véu, pedimos aos praticantes que se concentrem na totalidade do espaço que o corpo está ocupando, passando as ações que seriam executadas pela face para o tronco e membros.

Assim, a anti-máscara leva a ideia de retirar uma parte do corpo, o rosto, diferente do trabalho com máscaras que o rosto é substituído por outro, a anti-máscara retiramos fora o rosto, olhos boca, olhar, etc... É um corpo sem rosto, com a sua expressão exaltada. 


\section{CONCLUSÃO}

5.0.1 Onde trilhamos?

Algumas informações do mundo são selecionadas para se organizar na forma de corpo - processo sempre condicionado pelo entendimento de que o corpo não é um recipiente, mas sim aquilo que se apronta nesse processo coevolutivo de trocas com o ambiente. (GREINER, 2007, p. 130)

Essa pesquisa foi construída sobre duas bases, a reflexão sobre a questão corpo/mente partindo do conceito de paralelismo de Espinosa como fomentador ao treinamento prático e uma análise sobre a técnica do Mimo Corpóreo, onde fizemos uma proposta de organização de seus princípios e um estudo sobre a sua aplicabilidade através da separação entre princípios de criação e treinamento visando a aquisição de uma nova habilidade corporal; Também observando quais os conceitos voltados a criação pela proposta estética criada por Decroux para justificar a sua "nova arte".

Esse processo de organização foi importante para nós conceitualmente, trazendo argumentos para justificar nossa escolha em afirmar a aplicação do Mimo Corpóreo como habilidade corporal, assim possibilitando a criação de rotinas específicas, expostas no capítulo III, para esse fim, e também abrindo a possibilidade de propor aplicações de seus exercícios para a criação cênica.

A partir dessa base e sua conceituação, estudamos a importante questão da repetição dentro do treinamento de novas habilidades e também para exercícios de criação corporal, onde rotinas terão que ser repetidas exaustivamente.

Esse estudo sobre a técnica nos trouxe a ideia de três possibilidades de abordagem:

- O Mimo Corpóreo enquanto treinamento para o desenvolvimento de novas habilidades

- O Mimo Corpóreo enquanto estética quando aplicada junto com um conjunto de regras de aplicação

- O Mimo Corpóreo enquanto poética quando essa nova habilidade é utilizada de forma livre para a criação cênica 
Neste trabalho abordamos apenas sobre a primeira possibilidade, O Mimo Corpóreo como treinamento, e criamos um exercício cênico como exemplo de possibilidades da terceira opção, uma criação utilizando os princípios da técnica, essa performance será apresentada junto com a defesa e estará disponível no endereço virtual: spinoza.angatu.net

Sobre a questão do treinamento, a parte que nos interessou estudar foi a de como realizar as repetições, que começamos a explicar seus processos conceitualmente no capítulo anterior e aqui vamos explicar os procedimentos que utilizamos na parte prática.
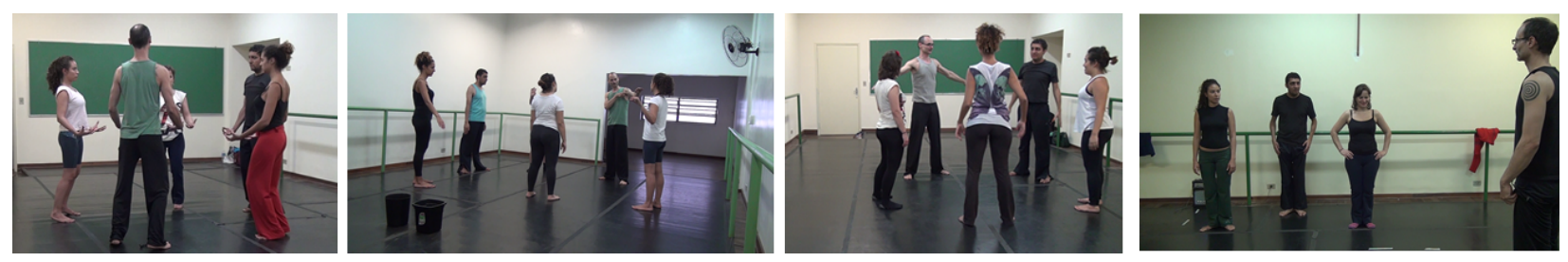

Figura 14 - Encontros do grupo de estudos 2014/2015. Fonte: arquivo do autor

5.0.2 O que fizemos?

Durante todo o período desta pesquisa foi mantido um grupo de treinamento, onde foi aplicado, experimentado e discutido exercícios relacionados a esse estudo e também da nossa prática pedagógica dos últimos anos em oficinas e workshops.

Dentro desse espaço montamos rotinas de trabalho experimentando formas de aplicação para alguns exercícios com o objetivo de compreender o que foi discutido no capítulo anterior, isto é, que partindo do conceito de paralelismo proposto por Espinosa, não impor situações hierárquicas na relação corpo/mente, pensar na repetição de formas corporais e na imitação de gestos como exercício dinâmico na aquisição de novas habilidades corporais e pensar na questão da aplicação da prática em criação cênica sem regras rígidas de utilização.

Esse estudo nos fez perceber as fronteiras que existem entre o processo de desenvolver uma nova habilidade física (pelo treinamento) e o processo de criação a partir da aplicação de uma técnica. O desenvolvimento de novas habilidades através de um treinamento de uma técnica específica tem características próprias e demanda um grande ideal de repetições, mas esse treinamento mesmo precisando ser mais objetivo neste caminho, não precisa ser algo frio e isolado da parte criativa. 
Podemos aplicar elementos sensíveis para que esse processo de repetição seja algo dinâmico e o praticante esteja sempre "presente", isto é, com a mente alinhada com o que o corpo está fazendo. Esse é o ideal que escolhemos para ser o valor padrão usado para o estudo da prática de repetição/imitação.

Iniciamos o estudo de manter a concentração dos participantes durante o treino pelo estudo da dificuldade dos exercícios. Percebemos que quando os alunos encontram dificuldade na realização das ações eles precisam estar "presentes" por inteiro para conseguir compreender e reproduzir o que foi demonstrado, e conforme essas ações vão se tornando mais fáceis de se realizar, mais familiares aos praticantes, não há mais a necessidade de uma concentração dedicada a ação.

Seguindo esse caminho, experimentamos manter sempre um alto nível de dificuldade como forma de manter a concentração "alta" nos exercícios, trazendo novos elementos quando esses começavam a se tornar familiares ao praticante, mas isso mesmo funcionando aparentemente, demonstrou ser extremamente desmotivante, além de ser cansativo para a maioria do grupo.

Sennett nos dá uma pista de como seguir, usando como exemplo o aprendizado musical, quando "a prática deixa de ser uma mera repetição digital para se transformar em uma narrativa" (SENNETT, 2009, p. 181.).

Esse foi o caminho que foi explorado dentro da prática desta pesquisa, quando os participantes do grupo de estudo começam a se sentir seguros com os exercícios e começam a repeti-los sem muita dificuldade, era o momento de transformar a repetição digital em repetição narrativa ${ }^{40}$, no lugar de aumentar a dificuldade do exercício em si, colocamos outros elementos como novas "camadas" dentro da prática.

Fazendo alguma coisa acontecer mais de uma vez, temos um objeto de reflexão; as variações nesse ato propiciador permitem explorar a uniformidade e a diferença; a prática deixa de ser mera repetição digital para se transformar numa narrativa; movimentos adquiridos com dificuldade ficam cada vez mais impregnados no corpo; o instrumentista avança em direção a maior habilidade. (SENNETT, 2009, p. 181.).

40. Assumimos na pesquisa o termo proposto por Sennett, "repetição narrativa”, como uma ação em camadas, uma camada com o desenho do movimento outra camada com um sentido que influência a dinâmica desse desenho. 
A primeira "camada" é a própria forma que o praticante tem que aprender a repetir, assim que ultrapassa essa epata ele terá que colocar novas camadas, que trazem a dinâmica a ação, para realizar essa prática experimentamos os diferentes exercícios:

1. Mesclar diferentes exercícios em uma única prática:

Inicialmente tentamos colocar juntas duas ou mais práticas interpoladas, o que aumentou o nível de dificuldade, mas sem muito sucesso. Acabamos abandonando essa tentativa e nos fixando no dinamoritimo, utilizando essa categoria da técnica em conjunto como outros exercícios na tentativa de criar micronarrativas.

2. Conscientização dos elementos "sensíveis":

Respiração, foco do olhar ${ }^{41}$, concentração presente/ausente ${ }^{42}$, pausas e suspensões.

Criando partituras destes elementos dentro da coreografia/ações junto ou com a dinâmica rítmica também com o intuito de gerar as micronarrativas.

Sobre o foco do olhar demos uma atenção especial a esse elemento trabalhando a realização dos exercícios: estudando a relação do olhar e foco, estipulando duas variações de focos, fixo e aberto, dentro de dois tipos, interno e externo. Podendo como exercício, coreografar o olhar, "marcando" dentro da realização dos movimentos os momentos que os focos devem mudar, definindo qual é o mais adequado, e observando a mudança na concentração e presença.

\section{Raccourcir:}

Aumentar e diminuir o tamanho do desenho do movimento, realizando o mesmo em diferentes proporções, estudando as diferenças nas intenções e a suas intensidades. Esse exercício é exclusivamente de exploração das possibilidades de uma coreografia/ação.

Exemplo: como realizar o exercício plástico com a metade da intensidade, tamanho ou realizá-la apenas com as mãos, olhos etc.

Esse exercício estuda "o tamanho" do movimento, tanto físico quanto por sua intenção (intensidade), tratando os dois como partes distintas de um mesmo. Treinar o dilatamento e a diminuição do movimento e a sua intenção, juntos e separados.

41. Foco fixo, foco aberto / fechado e olhar periférico.

42. Jogar com as possibilidades entre não estar concentrado na ação que esta sendo realizada e estar concentrado excessivamente no que se está se fazendo. 
Exemplo: aumentar o movimento, deixar que a intenção acompanhe, depois diminuir o movimento e manter a intenção alta.

4. Treino de micromovimentos:

Ainda dentro do treino do raccourcir, experimentar realizar o mesmo exercício em vários tamanhos e intensidades diferentes.

5. Treino com o véu, exercícios e improvisação:

Executar os exercícios com o véu e sem o véu, observar as diferenças na realização de cada forma, e com o uso do véu experimentar o conceito de mascaramento, o corpo como máscara, experimentando também improvisos com o véu.

6. O uso de música e musicalidades com os exercícios:

Experimentar realizar exercício de repetição em conjunto com músicas ou efeitos de musicalidade.

7. Aplicação imediata de exercícios de criação após o treino prático de exercícios de observação-repetição; composição de narrativas com elementos técnicos.

Após realizar exercícios que exigem a repetição de algum procedimento criar uma pequena narrativa (cena curta) com os elementos do mesmo. Seguindo o princípio da repetição-narrativa, construir pequenas cenas a partir da execução do exercício.

O resultado destas dinâmicas aplicadas nos exercícios baseados na repetição trouxe de volta o elemento da dificuldade, mas não como um obstáculo a ser ultrapassado, mas como um desafio a ser explorado. A ideia é de abordar a prática como um processo de pesquisa e descoberta contínua, pois diferente de repetir o gesto observado, a exploração não apresenta um resultado comum, e nem uma forma correta de realizá-lo.

Buscamos trabalhar os exercícios em camadas: a primeira camada é o movimento em si, o desenho que precisa ser repetido de uma forma já preestabelecida, e as outras camadas subjetivas que não tem uma forma correta ou comum de serem realizadas, que vão depender da experiência e disponibilidade de cada praticante. 


\subsubsection{O que encontramos?}

O estudo da técnica por esse viés foi extremamente enriquecedor, pois além de trazer desafios para os praticantes, com o elemento da exploração tanto das possibilidades expressivas como das sensíveis, também é um constante laboratório para quem está conduzindo, que constrói a prática junto com os participantes através do material expressivo que eles vão trazendo, questionando seus métodos e aplicações.

A prática neste formato desperta a curiosidade dos praticantes e estimula a criação. Durante o período de treinamento surgiram inúmeras ideias de possibilidades para os exercícios dos participantes que, motivados pela constante exploração de suas capacidades expressivas e sensíveis, se sentiam livres para criar, mesmo cercados pelas regras de aplicação dos exercícios.

Uma das descobertas mais importante durante o processo para os participantes foi que a perspectiva de treinamento em longo prazo, que de início parecia algo assustador (depois de apresentado o cálculo de 10 mil horas de Sennett), se tornou algo prazeroso. Pois com a mudança de perspectiva, atingir o objetivo de "dominar os movimentos" se tornou secundário nesse caminho de exploração das possibilidades do exercício. Isso apresentou possibilidades de caminhos para futuras organizações de processos de ensino em longo prazo da técnica do Mimo Corpóreo.

O fato de discutir os elementos teóricos e conceituais com o grupo também ajudou a “despertar o cientista" em cada participante, quebrando a formalidade convencionada na relação professor/aluno, gerando um ambiente mais criativo, onde todos estão abertos para o processo de descoberta.

Acreditamos também que esta pesquisa possa servir a outros processos de treinamento/criação, podendo servir de referência a qualquer outra prática corporal que sinta a necessidade de buscar elementos para discutir a sua aplicação e estratégias de realizar treinos onde se utiliza do elemento da repetição constante de exercícios.

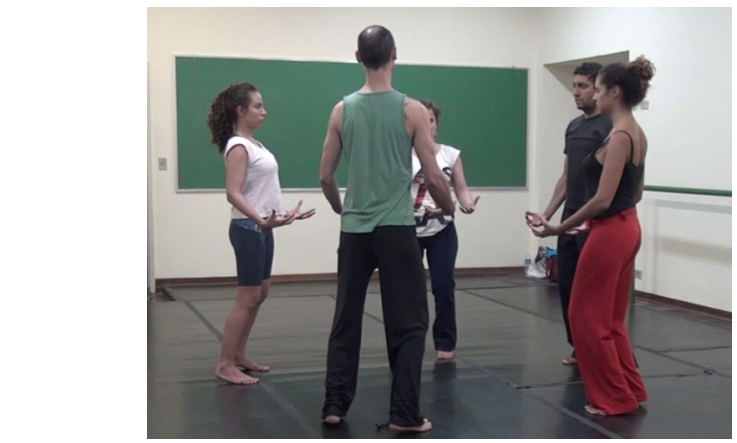

Figura 15 - Treinamento do grupo de Estudos. Fonte: acervo do autor 
5.1 Conceitos desenvolvidos e explorados durante o processo:

- Exercícios plásticos

São exercícios estilizados que trabalham na dilatação do gesto cotidiano. Alguns são relacionados a ações simples, como pegar e colocar um objeto, outros mais complexos, como o ato de se despedir, ou pequenas figuras relacionadas a ideias ou ações, sempre com a movimentação dilatada, fragmentada e estilizada (não realista).

- Escalas

Podem ser corporais, espaciais e na energia. É o exercício de divisão do corpo, espaço e o tônus de forma geométrica e matemática, e depois articular essas divisões separadas, combinadas e em dinâmicas (ondulação, contradição etc.).

- Micronarrativas

A questão das micronarrativas surgiu durante o treino de composição corporal, onde vários praticantes repetiam a mesma sequência de movimentos. $\mathrm{O}$ grupo analisando o exercício pós-prática, observou que algumas repetições eram interessantes de se olhar, enquanto outras repetições mesmo corretas não "chamavam a atenção" e davam a impressão de estarem vazias.

Buscando uma resposta para essa questão, repetimos várias vezes à mesma sequência de movimentos tendo em mente observar as pequenas diferenças que as execuções mais "interessantes" tinham de diferente das outras "menos interessantes". Percebemos que as que nos chamavam mais atenção eram repletas de pequenas ações, algumas quase imperceptíveis, como olhar, mudança na respiração, pausas e mudanças de ritmo.

Tomamos isso como exercício, preencher a repetição do movimento com o que começamos a chamar de micronarrativas, pequenas ações que demonstram um processo de pensamento/emoção por trás do movimento, como parte da própria execução do movimento. As micronarrativas são manifestações externas de uma ação interna, são, na verdade, uma demonstração sutil, quase imperceptível de processos de pensamento/emocionais do ser humano.

Essas dinâmicas podem ser criadas dentro de um desenho gestual ou coreográfico pela aplicação do estudo da dinâmica rítmica ou elementos sensíveis, como respiração, foco do olhar, pausas, etc. Com a intenção de demonstrar que existe um processo de pensar/sentir 
junto com a ação repetida, essas ações não interferem no roteiro externo do movimento realizado, servindo apenas como mudança de sua dinâmica.

- Repetição Narrativa

Como está explícito no nome, a ideia é agregar camadas por baixo do próprio movimento que tragam um "elemento narrativo" ou que ele sirva a narrativa de uma ação que necessariamente não esteja ligada a ele. Diferente do conceito de micronarrativas, onde construímos conscientemente uma dinâmica sensível nos movimentos, a ideia aqui é trabalhar com o movimento em conjunto com outros elementos que vão servir de estímulo para esta construção sensível de forma inconsciente. Por exemplo: imaginar realizar uma mesma ação em diferentes espaços geográficos, numa geleira no polo norte ou numa praia no verão. Essa camada "geográfica" trará mudanças na dinâmica do movimento (de fato mudanças maiores e mais perceptíveis que as micronarrativas). Essas camadas podem ser geográficas, sentimentais (raiva, medo, amor etc.), temporais (rápido, lento, fora do tempo), outros movimentos, texto falado ou qualquer elemento que agregue uma mudança na realização do exercício e esteja ligado com essa intenção narrativa.

- A Anti-máscara:

Usar o véu translúcido cobrindo a cabeça e rosto, como um mascaramento corporal, onde o rosto se torna o corpo todo, esse conceito de corpo-máscara é aplicado na prática como fomentador de estudo da percepção das subjetividades dos exercícios, dando a possibilidade dos praticantes experimentarem os estados diferenciados entre realizar exercícios com e sem o uso do véu, refletindo sobre a ideia de transformar o corpo em uma máscara com a retirada do rosto, este conceito se tornou algo de grande importância na pesquisa e está norteando boa parte do treinamento.

\subsection{Uma trilogia para criação}

Este trabalho não se propunha inicialmente a debruçar sobre a questão da criação cênica, algo que merece todo um estudo dedicado a isso, mas percebi que essa preocupação é algo constante em todas minhas ações, colocando ou não no papel, estou sempre em processo de busca de formas de aplicação da técnica para a minha criação cênica, a pesquisa e o espetáculo se pertencem. 
A pesquisa reconheceu que a composição corporal também faz parte do processo pedagógico, achamos de extrema importância acrescentar esta discussão através da inclusão de uma criação autoral, como estou aplicando a prática desta pesquisa em criações cênicas. Assim assumimos o exercício cênico, a sua criação e execução como parte integrante desta pesquisa.

Como disse não vamos nos debruçar conceitualmente aqui no processo de criação que precisaria de um estudo dedicado somete a essa questão, mas apresentar um trabalho cênico como demonstração de possibilidades.

O processo de estudo sobre a criação começou, na prática, por meio de um projeto chamado de "trilogia da dúvida", que contempla a criação de três espetáculos solos sobre a minha busca cênica/corporal, focando no Mimo Corpóreo a pesquisa sobre a criação dentro do ideal de uma dramaturgia corporal.

O projeto levou esse nome "trilogia da dúvida", pois se inspira em momentos de grande dúvida dentro da vida de figuras importantes para a história do pensamento ocidental, Charles Darwin, Giordano Bruno e Nicola Tesla, personagens que influenciaram a nossa história e ajudaram a construção do mundo contemporâneo.

Esses três pensadores têm em comum um momento de vida, onde eles poderiam ter abandonado seus ideais, mas escolhem seguir em frente, pagando o preço de suas escolhas, entrando para a história.

Cada um dos três espetáculos segue um gênero e estética distintos, promovendo o encontro do legado de Decroux com outros importantes criadores das artes cênicas, todos partindo sempre do corpo/movimento como elemento primordial na criação. O primeiro espetáculo é uma obra de teatro visual, com um diálogo de Decroux e o diretor polonês Tadeusz Kantor, o segundo é uma obra de dança-teatro, promovendo um encontro de Decroux com o coreógrafo norte-americano Bob Fosse e o terceiro será um espetáculo mais textual promovendo o encontro de Decroux com algum diretor mais ligado a escola naturalista.

Desta trilogia, o primeiro espetáculo é chamado de: "Tudo evolui exceto o coração dos homens", esse espetáculo fez a primeira temporada na cidade de São Paulo em Agosto de 2015, estreou em 2011 dentro do intercambio artístico com o centro cultural Comme Vous Émoi em Paris/França e já participou de vários festivais pelo Brasil e no Chile.

O segundo espetáculo se chama: "Infinita é a minha vontade ou um corpo em colapso pela razão instrumental" está em processo de elaboração, começando dentro do projeto: "LUGARIZAÇÃO” de residências coreográficas promovida pelo espaço O LUGAR da Cia 
Corpos Nômades em 2014 e foi também parte da residência coreográfica oferecida pelo CRD SP (centro de referência a dança da cidade de São Paulo). E a terceira parte se chamará: "TESLA, toda a energia em movimento".

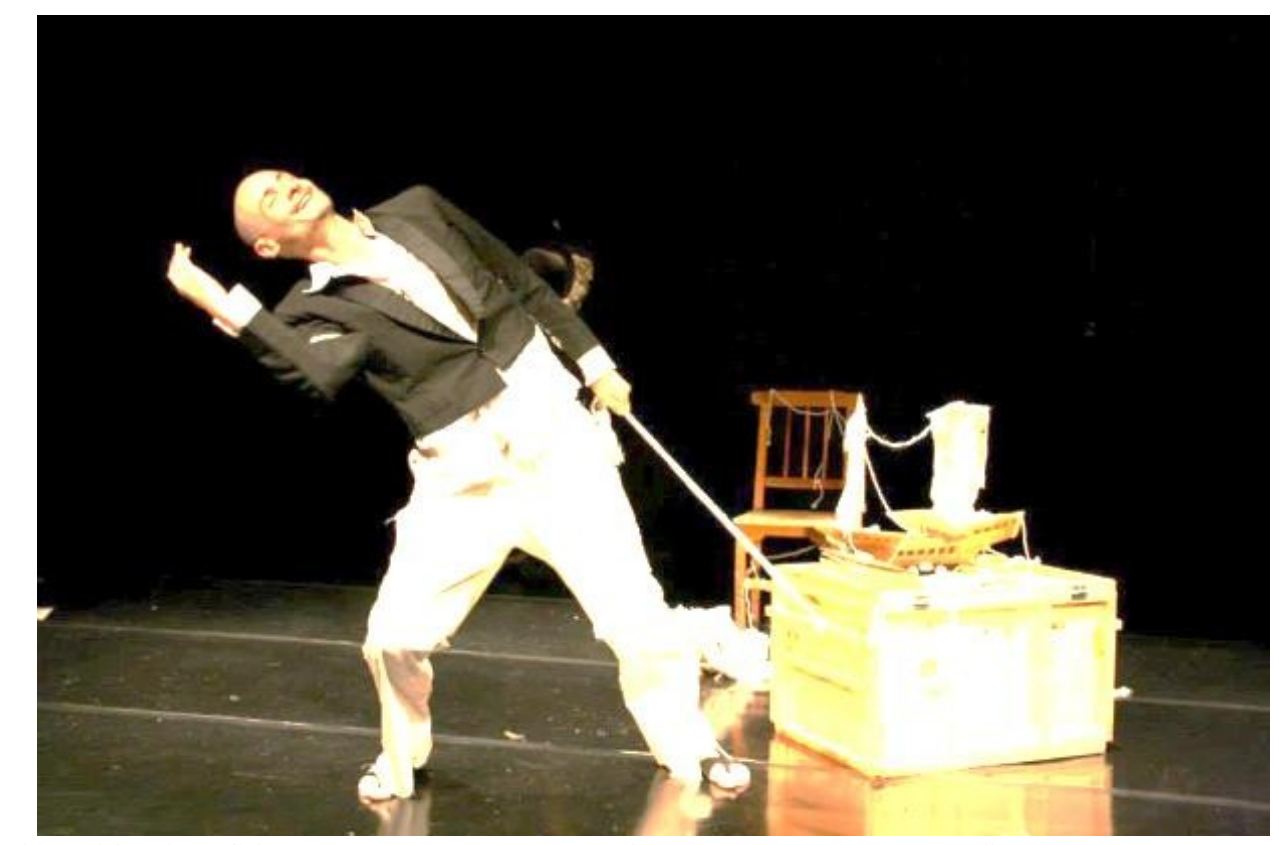

Figura 16 - Victor Seixas no espetáculo: “Tudo evolui exceto o coração dos homens”. Fonte: acervo do autor.

Esse projeto foi um grande laboratório para experimentação de diferentes possibilidades, abrindo uma gama distinta de formas de aplicar tanto os princípios da técnica como a "nova habilidade" que eu adquiri com os anos de treinamento como a aplicação de princípios da técnica na composição de cenas como na coreografia corporal dos espetáculos.

Essa trilogia veio com a ideia de defender a aplicabilidade tanto da técnica como do corpo treinado por ela em diversas possibilidades cênicas diferentes, criando espetáculo de gêneros distintos, afirmando o Mimo Corpóreo como uma técnica para a criação contemporânea.

Durante a defesa desta dissertação foi apresentado um exercício cênico chamado de $O$ universo de Espinosa, em que toda a parte conceitual do segundo capítulo desse trabalho (sobre o corpo) foi usada como roteiro para uma coreografia. Foram aplicados todos os princípios que estudamos aqui, explorando o corpo treinado por essa técnica. Na construção das coreografias os dinamoritimos mais os conceitos descritos aqui neste capítulo (micronarrativas, escalas etc.). Propomos três possibilidades de atuar corporalmente, que definimos da seguinte forma: 


\section{Corpo narrador}

Usar o corpo como metáfora para a representação/demonstração de algo que não pertence a ele, despersonificando-o e o reconstruindo dentro de outra realidade externa.

\section{Corpo sensível}

O corpo representa processos internos, emoções ou ideias e/ou como ele vivencia esses processos deixando claro para o espectador esse processo.

\section{Corpo presente}

Assumir a sua materialidade, peso e esforço através da presença em cena do intérprete em relação com o momento de encontro com a plateia, realizar ações dentro desta relação.

O DVD em anexo não tem a gravação desse exercício, que está disponível no endereço eletrônico: spinoza.angatu.net 


\section{Referências bibliográficas}

ANGER; Marie-Luise. Geometrie der Bewegung: Grundübungen des mime corporel von A bis Z. Germany: Henschel, 1998.

ALANIS; Leela. The Dynamo Rhythm of Etienne Decroux and His Successors. Scholarship. claremont.edu/mimejournal. Mime Journal, August 2013. ISSN 2327-5650 online.

AZEVEDO; Sônia Machado de. O Papel do Corpo no Corpo do Ator. São Paulo: Ed. Perspectiva, 2002.

BURNIER; Luís Otávio. A arte de ator: da técnica à representação. Campinas: Editora da Unicamp, 2002.

BARBA; Eugenio. A arte secreta do ator. São Paulo: Hucitec, 1995.

BERTHOZ; Alain. The Brain's Sense of Movement, Harvard University Press, 2000

BONFITO; Mateo. O Ator Compositor. São Paulo: Ed. Perspectiva, 2013.

CHAUI; M. Espinosa uma filosofia da liberdade. São Paulo: Moderna, 1995.

COPEAU; Jacques. Uma tentativa de renovação dramática. O teatro do Vieux-Colombier, p.19-32, in Registres I. Appels (Registros I. Apelos). Tradução de José Ronaldo Faleiro. Paris: Gallimard, 1974.

COPEAU; Jacques. Registres V: Les Registres du Vieux Colombier, II, ed. and annotated Suzanne Maistre Saint-Denis and Marie-Hélène Dasté. Paris: Gallimard, 1993.

COUTINHO; Eduardo Tessari. O Mimo e a Mímica - Uma Contribuição para a Formação do Ator Brasileiro. Dissertação de Mestrado. Universidade de São Paulo, 1993.

COUTINHO; Eduardo Tessari. Uma Cena Precisa - Procedimentos para uma Cena quase Pronta. Tese de Doutorado. Universidade de São Paulo, 2000.

DAMÁSIO; Antônio. O mistério da consciência: do corpo e das emoções ao conhecimento de si. Trad. Laura Teixeira Motta. São Paulo: Companhia das Letras, 2000.

DECROUX; Étienne. Words on Mime. Claremont: Pomona College Theatre Department for the Claremont Colleges, 1985.

. Parole sur le mime. Paris: Librairie théatrale, 1994.

. Mime corporel: textes, études, térmoignages. Saint-Jean-de-Vedas: L'entretemps éditions, 2003. Col. Lês voies de l'acteur.

DELEUZE; Gilles. Lógica do sentido. São Paulo: Perspectiva, 2006.

. Espinosa: filosofia prática. São Paulo: Escuta, 2002.

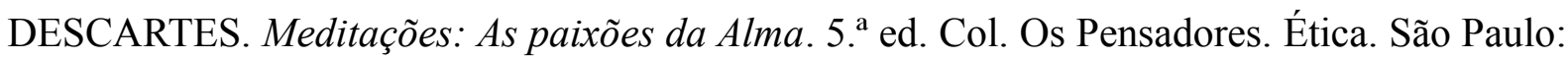
Nova Cultural, 1991.

DORCY; Jean. The Mime. New York: Robert Speller \& Sons, 1961

FELNER, Mira. Apostles of Silence: the modern French mimes. Paris: Fairleigh Dickinson University Press, 1985.

FERRACINI; Renato. Lume: 20 anos em busca da organicidade. Sala Preta, Brasil, v. 5, p. 117-128, nov. 2005. ISSN 2238-3867. Disponível em: http://www.revistas.usp.br/salapreta/article/view/57271/60253. 
FREIXE; Guy. La Filiation Copeau, Lecoq, Mnouchkine. Une lignée théâtrale du jeu de l'acteur. Collection Les voies de l'acteur. Paris: Aux éditions L'Entretemps 2014.

GLEIZER; M. Espinosa e a afetividade humana. Rio de Janeiro: Jorge Zahar Editor, 2005.

GREINER, Christine. O Corpo: Pistas para Estudos Indisciplinares. São Paulo: Annablume, 2005.

GUIRAUD; Pierre. A Linguagem do Corpo. São Paulo: Ed. Ática, 1991.

HAMIL; J. Biomechanical Basis of Human Movement. 4 ed., Philadelphia: Lippincott Williams \& Wilkins, 2015

HODGE; Alison. Actor training. London: Routledge, 2010.

HAGENDOORN; Ivar. Dance, language and the brain. Int. J. Arts and Technology, Vol. 3, Nos. 2/3, Inderscience Enterprises Ltd. 2010

KATZ; Helena. Um, Dois, Três. A Dança é o Pensamento do Corpo. Belo Horizonte: FID Editorial, 2005.

LEABHART; Sally. LEABHART; Thomas. An Etienne Decroux álbum/mime journal 2000/2001. Claremont: Pomona College Theatre Department for the Claremont Colleges, 2001.

. Jacques Copeau's School for actors/mime journal 1979. Claremont: Pomona College Theatre Department for the Claremont Colleges, 1979.

Words on Decroux/mime journal. Claremont: Pomona College Theatre Department for the Claremont Colleges, 1997.

. Incorporated Knowledge/mime journal. Claremont: Pomona College Theatre Department for the Claremont Colleges, 1995. 2007.

. Etienne Decroux. Routledge Performance Practitioners. London: Taylor e Francis,

. The Decroux Source Book. Routledge Performance Practitioners. London: Taylor e Francis, 2008.

Modern and Post-Modern Mime. Hong Kong: MacMillan Education LTD, 1989.

. Theatre and Sport/mime journal. Claremont: Pomona College Theatre Department for the Claremont Colleges, 1996.

LEBRETON; Yves. Sorgenti. Nascita del teatro corporeo. Itália: Editora Titivillus, 2012.

LECOQ; Jacques. The Moving Body. London: Methuen, 2000.

LUST; Annette. Bringing the Body to the Stage and Screen: Expressive Movement for Performers. London: Scarecrow Press, 2012.

MACHEREY; P. Introduction à l'Ethique de Spinoza, La deuxil me partie: Ia réalité mentale.

MARINIS; Marco de. Etienne Decroux and His Theatre Laboratory. New York: Icarus Publishing Enterprise and Routledge, 2015.

MASCARENHAS; George. A produção de sentido na Mímica Corporal Dramática de Étienne Decroux e na pantomima moderna. Revista Diálogos Possíveis, Janeiro/Junho de 2007 http://www.fsba.edu.br/dialogospossiveis. 2007 
MERLEAU-PONTY; Maurice. $O$ olho e o espírito. A dúvida de Cézanne. In: Textos selecionados. 2. ed. São Paulo: Abril Cultural, 1984. (Col. Os Pensadores) . Fenomenologia da percepção. Rio de Janeiro; Freitas Bastos, 1971.

MISHAHI; Robert. Le corps et I' esprit dans Ia Philosophie de Spinoza. Paris: G. Dagli Orti, 1992.

MOREAU ; J. Espinosa e o Espinosismo. Trad. Lurdes Jacob e Jorge Ramalho. Biblioteca Básica de Filosofia, 20. Lisboa: Edições 70 , 1982.

NEVES; Neide. A Técnica como dispositivo de controle do corpomídia. Tese de doutorado em comunicação e semiótica. PUC-SP, 2010.

NYE; Edward. Mime Music and Drama on the Eighteenth-Century Stage: The Ballet d'Action. UK: Cambridge University Press, 2011.

OLIVEIRA; George M. de. O devaneio do corpo: Princípios para a criação cênica em conexões com a Mímica Corporal Dramática na contemporaneidade. Tese (Doutorado em Artes Cênicas) - Programa de Pós-Graduação em Artes Cênicas. Universidade Federal da Bahia, Salvador, 2011.

PAVIS; Patrice. Dicionário do Teatro. São Paulo: Ed. Perspectiva, 1999.

PLATÃO; Fédon. Dialogo Sobre a Alma e Morte de Sócrates. Coleção: Obra Prima de cada autor. São Paulo: Martin Claret editora, 2002.

PINTO; Karen Astrid Müller. A Poética do Corpo em Movimento: do conhecimento à expressão. Tese de Doutorado, Universidade de São Paulo,2002

RENGEL; Lenira. Dicionário Laban. São Paulo: Annablume Editora, 2003.

ROPA; Eugênia Casini.(org Alete Cavaliere). Teatro russo, literatura e espetáculo. São Paulo: Ateliê Editorial, 2011.

ROUBINE; Jean-Jacques. A Arte do Ator. Rio de Janeiro: Jorge Zahar Editor, 1987.

. Introdução às grandes teorias do teatro. Rio de Janeiro: Jorge Zahar Editor, 2003.

SANTOS; M. P. Corpo: um modo de ser divino (uma introdução a metafísica de Espinosa). São Paulo: Annablume, 2009.

SCRUTON; R. Espinosa. São Paulo: Edições Loyola, 1996.

SENNETT; Richard. O Artifice. Trad. Clóvis Marques. Rio de Janeiro: Editora Record, 2009.

SEIXAS, Victor de. O caminho, as gerações e os desafios. In: Cadernos do Projeto Mímicas. no.01, São Paulo, Projeto Mímicas, 2009 p. 51-53.

SPINOZA, Benedictus. Ética. Trad. Tomaz Tadeu. Belo Horizonte: Autêntica Editora, 2009

Correspondance. Trad. Maxime Rovere. Paris: Editora GF Flammarion, 2010

. Pensamentos Metafísicos; Tratado da correção do intelecto. São Paulo: Nova Cultural Ltda., 1991.

SOUM; Corrine. Etienne Decroux e a Mímica Corporal Dramática. In: Mimus -revista online de mímica e teatro físico. Ano 1,no. 1, 2009. Disponível em <www.mimus.com.br>. Acesso em 2015. 
STELZER; Andréa. O corpo máscara do ator contemporâneo. Cadernos Virtuais de Pesquisa em Artes Cênicas. http://www.seer.unirio.br/index.php/pesqcenicas/article/view/705/645

TEIXEIRA; João de Fernandes. Mente, cérebro e cognição. 4 ed. Petrópolis: Vozes, 2011.

VARELA; F. Ciência Cognitiva e Experiência Humana. Trad. Joaquim Nogueira Gil e Jorge de Sousa. Lisboa: Instituto Piaget, 2001

. THOMPSON, Evan e ROSCH, Eleanor. A Mente Corpórea: Ciência.

ZARRILI; Phillip B. (Editor). Acting (Re)Considered: A Theoretical and Practical Guide (Worlds of Performance), Routledge; 2002. 


\section{Anexos}

7.1 Ações de divulgação do Mimo Corpóreo no Brasil

Apresentamos um breve relato de ações do Projeto Mímicas e outras duas importantes e pioneiras ações que ajudaram a promover o Mimo Corpóreo no Brasil, por meio de entrevistas com seus organizadores. A primeira ação conhecida de promoção e divulgação foi um projeto longo de oficinas e seminários realizado por George Mascarenhas e Nadja Turenko em Salvador no final da década de noventa até início de 2007 e o conjunto de oficinas ministradas por Ana Teixeira e Stephane Brodt, do Teatro Amok, sediado no Rio de Janeiro, também final dos anos noventa.

Queremos aqui apenas introduzir ao leitor as importantes iniciativas de divulgar esta arte e demonstrar que existiram ações concretas neste sentido, a grande parte das ações estão vinculadas a cursos e oficinas.

\subsection{O Projeto Mímicas}

Este projeto aconteceu entre os anos de 2004 e 2012, criado por Victor de Seixas e depois administrado por ele em conjunto de Rose Prado até o seu final, com o objetivo de fomentar à pesquisa, treinamento e conhecimento do Mimo Corpóreo.

Iniciado no ano de 2004 pela publicação do primeiro sítio na internet com informações em português sobre Etienne Decroux e o Mimo Corpóreo"s, o projeto começou a ter ações concretas a partir do ano de 2007, com o retorno de Victor de Seixas ao Brasil, começaram as oficinas e workshops, demonstrações e palestras regulares na cidade de São Paulo com a parceria da Oficina Cultura Oswald de Andrade ${ }^{\star}$ e o espaço cultural Condomínio Culturalss, os cursos regulares eram prioritariamente gratuitos e quando pagos com preços populares, e as palestras-demonstrações todas gratuitas.

Com o objetivo de realizar ações que fomentassem a pesquisa, treinamento e conhecimento do Mimo Corpóreo, bem como, apoiar e criar espaços para troca de saberes, divulgações, experimentações e aprimoramento, considerando seus diálogos contemporâneos

43. http://www.mimicas.com.br

44. Aparelho cultural vinculado a secretaria do Estado da Cultura no Estado de São Paulo

45. Espaço cultural no bairro da Pompéia na cidade de São Paulo - http://condominiocultural.org.br/ 
e interações com variadas linguagens e áreas do conhecimento. Dentre as principais ações do projeto foram:

- Mostra de Mímica Contemporânea

- Palestras e demonstrações regulares

- Núcleo de introdução e prática à Mímica Corporal e pesquisas cênicas corporais

- Site de pesquisas (www.mímicas.com)

- Publicação Impressa Anual (Cadernos do Projeto Mímicas)

- Oficinas, cursos e workshops

Em suas ações pontuais, o Projeto Mímicas recebeu a colaboração de artistas de áreas como: artes visuais, teatro e música, a fim de desenvolver novas possibilidades de comunicação e criação artística, além de disponibilizar informações e estudos.

Após o enceramento do projeto, foi mantido no ar o sítio na internet com mais informações e um canal no YouTube ${ }^{\star 6}$ com as filmagens das atividades desse projeto, oficinas, palestras etc.

7.2.1 A Mostra de Mímica Contemporânea:

Uma das ações mais importantes do projeto, a "Mostra de Mímica Contemporânea" aconteceu durante 5 anos consecutivos, as quatro primeiras versões na Oficina Cultural Oswald de Andrade e a última no Teatro Commune, sempre na cidade se São Paulo.

As últimas edições da Mostra foram um grande sucesso de público, recebendo pessoas de diversas áreas de interesse e de diferentes municípios e estados do Brasil, vindas exclusivamente para prestigiar as atividades da programação.

Além de receber um incrível retorno dos artistas convidados e do público frequentador da mostra, a sua produção recebeu propostas de grande qualidade artística de grupos, coletivos e artistas brasileiros e estrangeiros, para espetáculos, performances, cursos e outras atividades, demostrando o grande potencial dessa iniciativa e grande reconhecimento deste árduo trabalho.

A Mostra de Mímica Contemporânea abriu um espaço ímpar dentro do quadro das artes cênicas no Brasil. Foi o único evento em nosso país voltado exclusivamente a reflexão e à pesquisa do Mimo Corpóreo através do encontro de diferentes grupos de artistas, pesquisadores e pensadores sobre esta arte e assuntos correlacionados. A partir de encontros

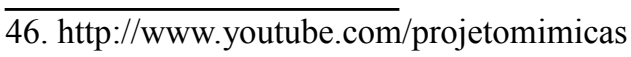


entre nomes mundialmente consagrados, pesquisadores acadêmicos, artistas, grupos e coletivos artísticos, estudantes, entre outros interessados, de modo plural, buscando a ampliação de olhares sobre a arte do Mim Corpóreo (ainda vista de forma pouco abrangente em sua complexidade de gêneros, pesquisas e criações), novas perspectivas e diálogos entre distintas estéticas e áreas do conhecimento.

Histórico da mostra de mímica contemporânea:

V Mostra de Mímica Contemporânea - DEZEMBRO DE 2012

Durante três dias em Dezembro de 2014, com o apoio do edital IBERESCENA a Mostra apresentou trabalhos inéditos na cidade trazendo companhias do Chile, Rio de Janeiro e Fortaleza, abrindo espaço para duas atividades inéditas, uma noite de improvisos corporais (WAM BAM) e a apresentação de trabalhos curtos e em processo de pesquisa no Lab@Corporal, além de oferecer oficinas e um JAM corporal no final, esta edição da Mostra foi a primeira a acontecer fora da Oficina Cultural Oswald de Andrade, e aconteceu no Teatro Commune na Rua da Consolação no centro de São Paulo.

Participantes:

- Cia Trupiniquim - Rio de Janeiro/RJ

- Cia LaEscenaFisica - Santiago/Chile

- Tomaz de Aquino - Fortaleza/CE

- Chantal Mailac - Líbano/Brasil

- N.I.C ${ }^{2} O$. - São Paulo/SP

- Colectivo El Sotano - RS/SP

- Gabriel Riquelme - Santiago/Chile

- Ricardo Contreras - Santiago/Chile

- Prof. Francisco Conte - SP

IV Mostra de Mímica Contemporânea - SETEMBRO DE 2012.

Criação e Pesquisa na Mímica Contemporânea

De 21 a 29 de setembro de 2012, a quarta edição da mostra focou sua curadoria na produção nacional, fazendo um breve apanhado de companhias com produções contemporâneas voltadas à pesquisa de linguagem e criação, trazendo artistas de quase todas as regiões brasileiras e abrindo a discussão sobre a composição corporal para o teatro contemporâneo, realizando também algo inédito, conseguindo reunir em sua abertura os 
principais mímicos de São Paulo e alguns convidados de outros estados para realizarem uma cena curta na abertura da Mostra.

Grupos/artistas:

Sonhus Teatro Ritual (GO)

LaescenaFísica com Ricardo Gaete, Chile (Santiago)

Coletivo El Sótano (RS)

Angatu, Brasil (SP)

Mimus - Companhia de Teatro (BA)

Refinaria de Theatro (SP)

Grupo Gestos Sonoros (SP)

Chantal Mailhac, Líbano

Dyego Stefann (CE)

Denise Namura, França

Bru Palmieri (SP)

Neide neves (SP)

Atividades:

Lançamento do quarto caderno do "Projeto Mímicas".

Encontro de Mímicos (abertura)

5 espetáculos e 2 performances

8 workshops e um colóquio com 5 convidados

JAM de enceramento.

III Mostra de Mímica Contemporânea - SETEMBRO 2011.

Vinte anos sem o Pai da Mímica Moderna, Étienne Decroux (1898-1991).

De 16 a 30 de setembro de 2011, a terceira edição da mostra homenageia Étienne Decroux, em seus 20 anos de falecimento, trazendo artistas como Marise Flach, sua primeira assistente em 1950 e também testemunha e grande colaboradora na elaboração dos fundamentos da linguagem "Mímica Corporal Dramática".

Grupos/artistas:

Convidada de Honra: Marise Flach (França/Itália - Piccolo Teatro di Milano)

Platform 88, França (Paris)

Ricardo Gaete, Chile (Santiago)

Moveo (Barcelona - Espanha - Vídeo Conferência) 
Angatu, Brasil (SP)

Mimus - Companhia de Teatro, Brasil (BA)

Amok Teatro, Brasil (RJ)

Cia. Luis Louis, Brasil (SP)

Solar da Mímica (SP)

Atividades:

Lançamento do terceiro caderno do "Projeto Mímicas".

Encontro de Mímicos (abertura)

6 espetáculos de companhias Brasileiras.

3 espetáculos de companhias estrangeiras

3 workshops com grupos Brasileiros

3 workshops com grupos estrangeiros

\section{MOSTRA DE MÍMICA CONTEMPORÂNEA - AGOSTO 2010.}

Caminhos, Perspectivas e Diálogos da criação.

Novas mídias culturais (performance, vídeo-instalação, instalação sonora, corpoinstalação, artes inter-disciplinares) culminam e são provocadoras das ações e pensamentos do mundo contemporâneo. A mostra fomenta as reflexões sobre a criação contemporânea brasileira sob diversos aspectos e olhares, a partir da participação de profissionais de diferentes áreas, tais como: Dança, Semiótica, Filosofia e Ciência, como a Profa. Dra. Helena Katz (PUC-SP e crítica de dança do jornal Folha de São Paulo), o Professor Dr. Antônio Alfredo Telles de Carvalho (UNEAL/AL e PB), a Profa. Dra. Fernanda Carlos Borges.

Além destes profissionais, a mostra tem a satisfação de trazer o mais importante autor sobre a Mímica Contemporânea, o Professor e diretor Thomas Leabhart (Pomona College Califórnia - EUA), um dos assistentes de Etienne Decroux, para a coordenação de um treinamento intensivo, palestra e apresentação de espetáculo-demonstração.

Atividades:

Espetáculos, workshops, exposição de arte-tecnológica, performance urbana, lançamento do Caderno 2 do Projeto Mímicas, palestras, JAM e Mesa Redonda. Além dos acessos presenciais, este ano os acessos às atividades se ampliam a partir da transmissão via Internet. 


\section{MOSTRA DE MÍMICA CONTEMPORÂNEA - JULHO 2009.}

A Mímica Corporal Dramática no Brasil e o Legado de Etienne Decroux.

Em parceria com o Espaço Cultural Pyndorama, a primeira mostra integrou o "II Colóquio Pyndorama" (série de encontros anuais, para reflexões e estudos sobre a corporalidade do artista cênico).

A I Mostra de Mímica Contemporânea veiculou ao grande público os princípios, conceitos e a estrutura técnica da Mímica Corporal Dramática, linguagem desenvolvida pelo artista francês Etienne Decroux (1898 - 1991), da qual partem os principais estudos e criações da Mímica Contemporânea, além de criar espaço para troca de saberes entre profissionais da Mímica de diferentes regiões, especialistas na linguagem atuantes no Brasil.

Profissionais participantes: George Mascarenhas (Padma - BA); Renato Ferracini (Unicamp/SP); Lenira Rengel (UFBa); Ana Teixeira (Amok Teatro - RJ); André Guerreiro Lopes (Lusco-fusco - SP); Nadja Turenko (PA/SP); Alexandre Brum Correa (RS/SP), além da curadoria, produção, coordenação de workshops e apresentação de espetáculos dos profissionais do Projeto Mímicas - Angatu (Victor de Seixas e Rose Prado).

Atividades: palestras, workshops, exposição, lançamento da primeira edição dos Cadernos do Projeto Mímicas e espetáculos.

Cartazes da I Mostra de Mímica Contemporânea e Colóquio pré-mostra:
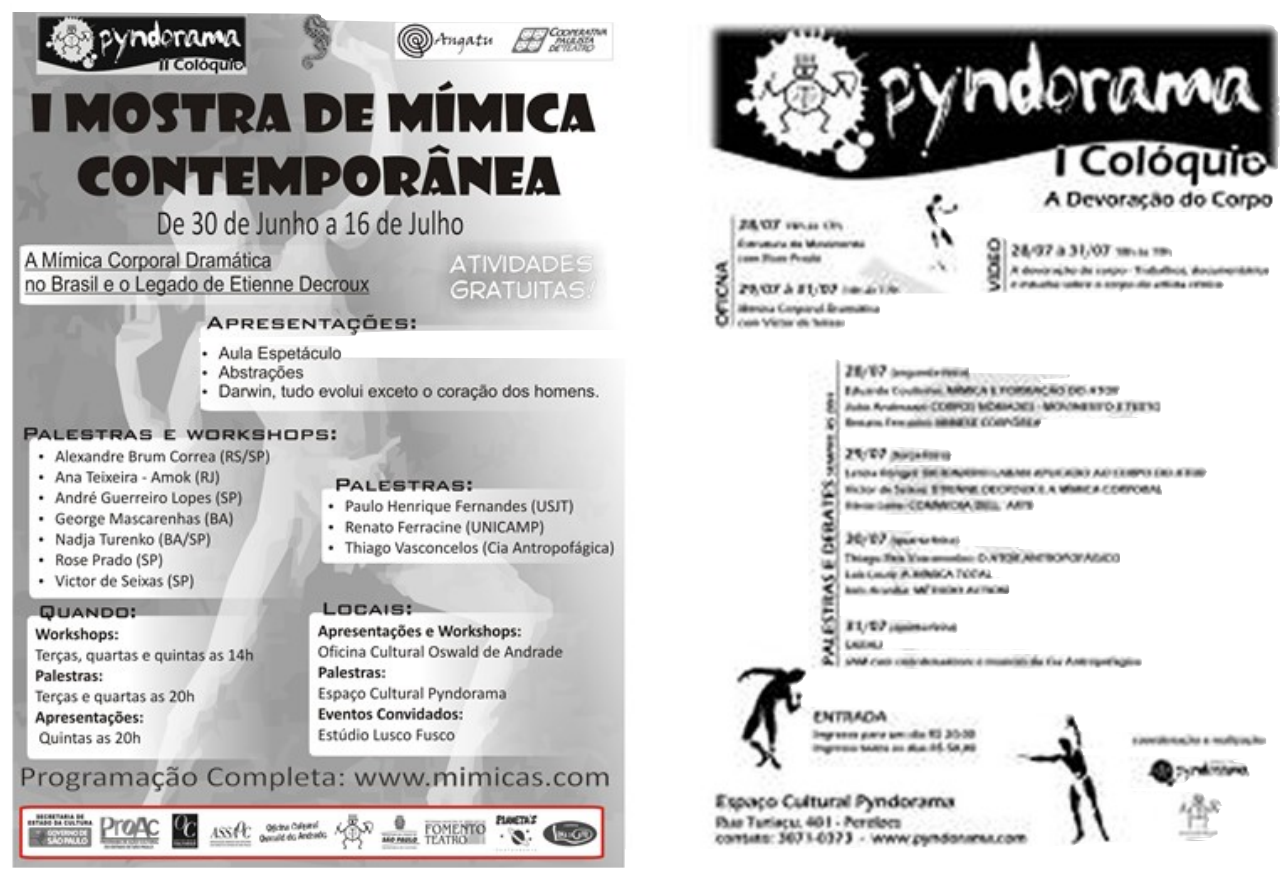
Cartazes da Mostra de Mímica Contemporânea:
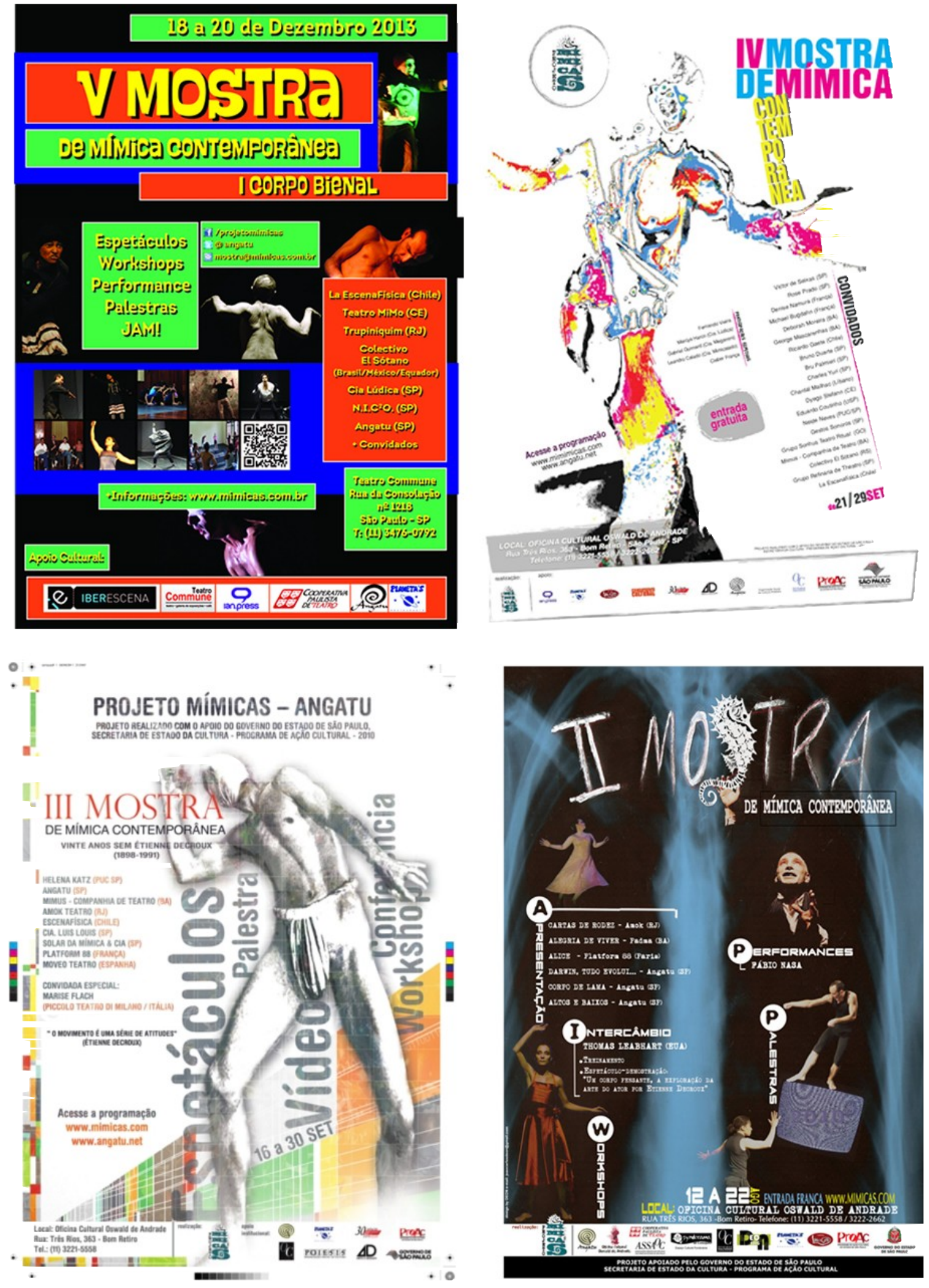
7.3 Entrevista com George Mascarenhas(*) - Julho de 2016

\section{PERGUNTA: Você coordenou um projeto que ministrava cursos regulares em} Salvador, fale um pouco sobre esse projeto.

$\mathrm{Na}$ verdade, a gente nunca teve um nome específico de projeto, às vezes a chamávamos de curso livre de Mímica Corporal Dramática e em outras ocasiões era curso permanente de Mímica Corporal Dramática, sempre um nome ou outro assim, com a ideia de manter o curso permanente. Nadja ${ }^{47}$ voltou da França em 95 e deu uma oficina na escola de dança da UFBA, e no ano seguinte ela abriu outra turma e manteve as aulas regulares, assim começou a nascer essa ideia. Eu tinha ido para a Inglaterra, e quando eu voltei, porque eu tinha feito uma parte do curso em Paris ${ }^{48}$, em 95 eu voltei para cá antes de ir para a Inglaterra também em 95, porque a escola se mudou. Então ela começou sozinha nesse período.

Foi aí, quando eu voltei definitivamente, que a abrimos esse curso e começamos a trabalhar juntos. Esta proposta inicialmente era vinculada, quer dizer, não tinha um vínculo formal como hoje em dia, mas era como um projeto de extensão dentro da escola de teatro da UFBA, estávamos em contato direto com a diretora da escola e eles tinham muito o interesse de projetos de extensão, porque tinha outros projetos e a gente dava aula na escola de teatro da UFBA de meio dia as duas. Esse era o horário que tinha sala de aula disponível e era um horário que muitos alunos aproveitavam, quem estudava de manhã e de tarde podia fazer aula e funcionou muito bem assim durante um tempo.

Foi nesse período então, a partir disso que a gente começou a dizer que era um curso livre, nunca foi assim um projeto planejado no sentido de isso vai ser de longo prazo ou não, o que a gente queria era manter permanentemente um curso de mímica onde as pessoas pudessem ter uma experiência como a nossa experiência na escola de Steven e Corinne ${ }^{49}$, um curso permanente, um lugar onde as pessoas pudessem estudar mímica.

Então fizemos isso durante esse tempo na escola de teatro e em seguida, sempre eu e Nadja, fomos professores substitutos na escola. Depois disso a escola começou a fazer uma reforma e aí a gente ficou sem espaço sem sala. E ficou bem complicado por causa do processo de reforma, a escola perdeu salas e a gente começou a fazer isso em outros lugares.

47. Nadja Turenko

48. "International School of Corporeal Mime". A escola mudou-se da França para a Inglaterra, onde ficou até seu fechamento.

49. Professores da escola, últimos assistentes de Decroux 
Então, nós fomos para vários lugares até que a gente se instalou no Theatro XVIII, no seu anexo que ficava no Pelourinho. O Theatro XVIII era um projeto de duas artistas daqui de salvador (Aninha Franco e Rita Assemany) que tinham o apoio do estado pela lei estadual de incentivo e a ideia de que esse espaço fosse um espaço público, mesmo que um projeto particular, elas tinham uma política de ingressos com valores simbólicos, tinha uma subvenção uma parte pelo estado e outra pela iniciativa privada pela lei estadual, não lembro se chegou a ter alguma coisa com a lei Rouanet na época.

Mas era um teatrão sempre frequentado, tinha projetos a semana toda, só um dia na semana que era folga, tinha também leituras dramáticas e tal. E tinha a casa anexa, o casarão que era lá no pelourinho também junto ao teatro, a casa vizinha, a casa 14. E nessa casa que conseguimos um espaço, um espaço grande, que tinha espelhos, um tablado, enfim, a gente começou a dar aula lá e nesse momento foram várias iniciativas assim, a gente cobrava muito pouco, era uma mensalidade bem simbólica e às vezes quem não podia pagar não pagava, tinha uma relação bem fácil de negociar, pois o objetivo era manter essa oficina, isso durou até o ano de 2006, quando a gente acabou. Simultaneamente tínhamos o grupo, trabalhávamos juntos e naquele momento o grupo acabou também, e as oficinas pararam ali naquele ponto.

Final de 2006 talvez pegando o verão, ou talvez em 2007 no verão, acho, que Nadja ainda deu uma oficina, mas não era mais o coletivo, era dentro do projeto pessoal dela e seus desejos, eu estava viajando... Então a gente conta assim esse projeto durou pelo menos 10 anos, teve oficinas permanentes todos os semestres a gente tinha o esquema de combinar com o período escolar, então dávamos aulas normalmente de março a junho após agosto/final de julho até dezembro o segundo semestre era sempre um pouco maior.

O segundo era sempre maior que o primeiro então a gente aproveitava o segundo para fazer uma mostra didática durante todo o tempo de curso a gente construiu uma mostra didática com os estudantes no final, apresentando em vários lugares. A última mostra didática que a gente fez, já foi dentro de um teatro, eu trabalhei em uma escola que era a faculdade social da Bahia, lá tinha um curso de artes cênicas, de nível superior, um bacharelado e uma licenciatura, e eu conduzia um projeto chamado de quartas cênicas, onde tinha liberdade de fazer o que queria, e uma das coisas que fiz foi colocar a mostra lá, o teatro de lá tem 500 e sei lá ...

Foi casa cheia, todo mundo querendo entrar foi bem assim, essa foi a última mostra, e era baseada em um texto de uma pessoa daqui. Um texto chamado: Formigas de Fogo, preciso procurar o nome do autor... 
O curso tinha a as aulas de técnica e improvisação e composição, no final a gente juntava tudo isso e fazia as mostras didáticas, eu e ela dirigíamos e os alunos apresentavam cada um apresentando a sua própria composição, o que eles tinham construído artisticamente. O que a gente fazia era amarar uma coisa na outra dar uma cara, combinar um figurino, trazer umas músicas, enfim, a gente organizava isso rapidamente, sempre tomava do curso em torno de duas semanas antes da mostra, só ensaios, amarração, vem para cá, junta isso com aquilo, faz essa sozinho... Uma organização dessas composições que eram criadas.

E lateralmente a gente tinha várias coisas que aconteceram e que junto na verdade com o curso, porque era um pouco a consequência do curso um pouco a partir da cidade saber que a gente tinha essa experiência, que foram os trabalhos ligados com as instituições a gente fez a preparação e dava aula de mímica para o projeto axé, você sabe o que é o projeto axé, não sabe?

\section{PERGUNTA: Não.}

O projeto axé é um projeto aqui de salvador que é dirigido por um italiano, Cesare de la Rocca, ele veio para cá e ficou um assustado coma situação das crianças de rua e ele começou a fazer um projeto que busca de algum modo dar dignidade e respeito para essas crianças. Então era um projeto que trabalhava particularmente com menores de rua, jovens e crianças ou abandonadas ou que tem família, mas que vivem em situação precária socialmente.

É um projeto enorme, eles trabalham especialmente pela educação com a arte, que é um dos focos. Uma das exigências é que a pessoa vá para a escola formal também, eles têm aulas de moda, música, dança, não tinha teatro tinha música e dança fortemente, mas não tinha teatro então o THEATRO XVIII, essas duas pessoas, Rita Assemany e Aninha Franco propuseram ao axé criar o grupo de teatro do axé e eu e Nadja trabalhamos com os adolescentes e esse grupo de teatro que veio a ser abrigado pela Casa XIV dentro do projeto do Theatro XVIII.

A gente dava aulas de mímica e fez a preparação para o espetáculo que Nadja dirigiu "Os miseráveis" de Víctor Hugo uma adaptação de Aninha Franco que era a diretora do THEATRO XVIII que é dramaturga também, então isso era uma coisa que aconteceu.

Outra coisa que aconteceu como projeto grande, foi: aqui tem uma escola chamada liceu de artes e ofícios da Bahia era uma instituição muito importante porque trabalhava com uma capacitação profissional formava pessoas para especialmente para os ofícios assim 
confecção de moveis assim coisas desse tipo e depois de um tempo também para as artes e na época que o liceu funcionou, nesse período as oficinas de artes eram muitos importantes.

Tinha grupo de dança e teatro e tinha aulas e houve uma época que o a secretaria de educação estadual entrou em contato com o liceu para que eles pensassem em algum projeto que pudesse ajudar a secretaria estadual a diminuir a quantidade de moveis que eram depredados na escola porque o mobiliário era destruído por várias razões... Aí teve uma equipe interdisciplinar enorme, e eles fizeram um trabalho e chamaram o um diretor teatral que era o Luís Marfuz para pensar isso junto e tal, que era do teatro.

E foi feito um projeto chamado de "cuida bem de mim" que era inicialmente era para falar disso, tratar da manutenção ou do cuidado da preservação do mobiliário escolar, mas com o convívio com os alunos com os estudantes na escola e professores e etc. começaram a aparecer outras questões especialmente quer dizer, a destruição do mobiliário era um sintoma das escolas, não era o problema principal e começaram a descobrir quais eram esses problemas, questões ligadas a violência e as drogas, das diferentes facções dentro das escolas... E foi feito o projeto "cuida bem de mim".

Esse projeto inicialmente foi feito com atores profissionais e esses atores profissionais foram treinados por Nadja com a mímica e depois de um tempo o projeto foi retomado pelo liceu ficou em cartaz durante muito tempo. Essa peça teve um número de espectadores absolutamente enorme, mais de 250 mil!

E depois disso o projeto quando acabou 3 ou 4 anos depois o liceu o retomou por causa da secretaria de educação, mas dessa vez foi feito não com atores profissionais, mas os próprios estudantes das escolas.

Fizeram seleção nas escolas públicas, os alunos se candidatavam por meio de uma de audição e esses foram escolhidos para terem um ano de oficinas e participar de algo que eles não sabiam ainda o que era, mas que no fim das contas eles entenderiam que fariam o "cuida bem de mim" que eles já tinham assistido na escola inclusive. Todo mundo já conhecia a peça. E nesse momento eu dei treinamento com a mímica e acho que fiquei no liceu, acho que uns 4 ou 5 anos pelo menos, porque ai tinha o primeiro elenco e tal, depois começou a ampliar entrarem novas pessoas, substituiriam etc.

E durante esse tempo aconteceu o "cuida bem de mim" com os estudantes das escolas públicas e todos eles formados com a mímica embora a peça tivesse de uma estrutura assim, era bem realista, nessa direção, mas tinha alguns momentos em que o jogo era permitido no sentido de ampliar o movimento para que os atores tivessem mais presença cênica, uma 
coluna mais firme, estados diferentes... Então o trabalho era bem intenso assim com aulas quase todos os dias e depois disso muita gente continuou trabalhando, alguns desses estudantes se apropriaram do trabalho e trouxeram para seus trabalhos ou como atores ou como professores algumas informações da mímica... Entendeu?

Então eram coisas paralelas a oficina que acontecia e aconteceu durante muito tempo, sempre nesse horário a gente trabalhou nesse horário de meio dia as $14 \mathrm{~h}$ era um horário de trazer pessoas e algum momento acho que teve aulas noturnas mas acho só quando Nadja estava dando aula, logo no início as aulas eram a noite depois a gente trouxe para a tarde e o curso funcionou sempre nesse horário assim a gente deu aulas nas férias cursos intensivos as vezes cursos só de repertorio, coisas assim pontuais mais concentradas e isso aconteceu durante muitas e muitas vezes duramente esse tempo.

\section{PERGUNTA: Quantas pessoas participaram desse projeto além de você e a}

\section{Nadja?}

Após um tempo com o tempo a gente começou a ter alguns alunos avançados e uma aluna avançada desse curso foi a Deborah Moreira no fim das contas porque ela começou desde a primeira turma e ela foi seguindo e foi se aperfeiçoando e tal. Ela chegou a um ponto que ela era nossa assistente dentro do trabalho, ela conduzia um dia de aula, e a gente começou a fazer uma preparação com ela para que ela pudesse também não só assumir isso de dar aula como também ter para ela a técnica.

Então ela tinha uma tutoria especial a gente treinava separadamente com ela... O nosso desejo é que tivessem outras pessoas... A gente viveu muitas coisas assim, por exemplo, de gente muito bacana que fazia um semestre e tal, mas saia porque tinha que ir para universidade ou mudava de lugar ou não podia ou tinha que trabalhar no horário, enfim várias situações.

A partir de determinado tempo Deborah não ficou somente nesse lugar de nossa estudante mais avançada dentro da técnica, pensamos em realmente fazer um projeto assim de que ela pudesse ser diplomada como a gente tinha sido pela escola. Passar por um ritual de fechamento de ciclo e tal. E isso aconteceu, ela foi para Londres ficou um tempinho na escola que era o período das férias dela, fez aulas com Steven e Corinne, nós conversamos com eles e eles deram o aval que podíamos dar o diploma a ela.

E a gente passou o ano todo treinando. Ela era a primeira pessoa que achamos que poderia ter um diploma de mímica neste projeto. E fizemos todo o ritual, igual à gente fez 
também na escola de Londres, ela teve que apresentar uma conferência demonstração, apresentou as figuras e peças e tal e no fim das contas a gente ofereceu o diploma, foi bem simpático! Então ela é a pessoa que se formou dentro desse projeto, dentro da mímica com a diplomação nossa dentro desse tempo que ele funcionou...

$\mathrm{Na}$ verdade, o que a gente queria era ter um curso permanente aonde as pessoas pudessem vir fazer e experimentar a técnica, porque ninguém a conhecia, e ninguém conhece ainda. Você sabe. Ninguém sabe o que é isso até hoje você fala e parece que continua falando grego, hoje em dia por causa dessas experiências, Salvador é uma cidade pequena nesse sentido, da comunidade de quem circula pelo teatro e tal.

Então muita gente escutou o galo cantar e não sabe onde foi tem muitas referências que voltam a informação faz um círculo e quando volta para você volta e você faz assim: anh? Não é bem isso...

Às vezes você ouve assim, por exemplo, coisas do tipo: mas é muito rigoroso! Ou o que pode e que não pode... Isso de gente que nunca pisou na sala que nunca veio experimentar uma oficina... Eu me lembro de uma situação, a gente participou de um evento e uma das pessoas presentes dizia, quando Nadja estava explicando sobre a mímica, ela dizia assim: Eu conheço muito sobre Decroux, e a gente tomou um susto, porque na verdade compreendíamos que era uma coisa muito nova e absolutamente desconhecida, e ai as informações que a pessoa trazia eram informações meio esquisitas, na verdade, a gente começou a entender de que precisava ser construído primeiro uma compreensão do que se estava fazendo e que era isso, do que era a técnica e tal...

Então durante um determinado momento o curso cumpriu esse papel, ter na cidade um lugar de referência onde se estudava e o que era aquilo, então a gente sempre abria as oficinas com uma espécie de conferência demonstração sempre quando tinha durante a mostra didática era situada aquilo como uma mostra didática e a gente explicava todo o contesto da mímica, o que era e não era, explicando as pessoas sobre como era todo o trabalho mesmo para as pessoas que vinham assistir justamente para de algum modo marcar esse entendimento do que a gente estava fazendo ali... Então tínhamos essa preocupação didática... Na cidade de explicar e cumprir esse papel... Assim quisemos ter o curso permanente pelo desejo de continuar dando aula porque isso e um modo de você continuar estudando também, praticando e tal.

Com o vínculo das aulas a gente conseguia manter um treinamento mais eficiente também nos horários antes da aula e tal e mesmo nos outros dias que não tinha aula, podíamos 
estudar coisas diferentes para ajudar na aula... Então tinham várias funções para a gente, mas não tínhamos uma meta assim, vamos ter 30 ou 40 alunos, as vezes tinham 25 alunos.

Quando as oficinas eram gratuitas, por exemplo... A gente abriu no THEATRO XVIII, as oficinas entraram num projeto no seu primeiro ano elas eram gratuitas. Quando a gente fez isso, tivemos 120 pessoas inscritas. Tivemos que fazer uma seleção, mas quando era pago, mesmo com uma mensalidade simbólica, às vezes a gente tinha 20 alunos e às vezes reduzia para 15 e a gente terminava com 9 ou 10 no final do semestre. Também, porque se tinha uma exigência com a presença e um compromisso com as aulas, lá pelas tantas quem via que não ia dar conta não ficava e ia embora, uma espécie de seleção natural.

Também, a gente não fazia um esforço de sedução, no sentido de adaptar, no sentido de facilitar. A gente não tinha essa preocupação. Era um modelo de aula inclusive muito próximo ao que a gente tinha na escola e com o rigor também no trabalho e com o trabalho, com a técnica.

\section{PERGUNTA: Você tem ideia de quantas pessoas passaram pelas oficinas?}

Funcionou assim, eu me lembro de ter feito uma conta só por alto, porque alguém perguntou para a gente sobre esse período de 10 anos. Nós, tivemos no total, contando todos os alunos que participaram, os elencos que a gente preparou também entram nessa conta, assim por cima foram mais de 1.200 pessoas que participaram desse projeto de algum modo.

Então isso cria uma espécie de massa crítica, cria uma referência embora absolutamente diluída também porque nunca não é muito claro esse lugar de comunicação de entendimento mesmo do que se faz do que é e que não é e tal mas foi um momento rico assim, muito divertido também, e quando eu voltei da Inglaterra, assim, uma coisa que a gente começou a fazer que não tinha antes era o estudo do repertorio de Etienne Decroux, isso não tinha os meninos aprenderiam "a usina", a gente fez "a usina" com os alunos, a gente fez "a lavadeira", "o carpinteiro" a gente fez até "o jornal", "La femme oiseau", a gente fez muitas coisas do repertório, tanto dentro do período normal digamos como nos cursos de férias.

$\mathrm{Na}$ verdade, um curso que era bastante espelhado na experiência da escola de Steven e Corinne, bem estruturado assim, com a s quatro disciplinas aulas de técnica, improvisação composição e finalmente começamos a incluir o repertório. O repertorio sempre foi como estudo nunca foi apara a cena nunca apresentamos em mostras didáticas nada disso o repertório claramente como possibilidade de estudo. E os alunos avançaram tecnicamente quando começávamos a estudar o repertorio. 
Também tinha um detalhe que era o seguinte: a gente teve alguns alunos que continuaram de um ano para o outro, então quando chegava no início tinha um monte de gente nova que entrava, o começo sempre era assim uma revisitação, sempre tinha também aquele jogo entre os avançados e os iniciantes. Os avançados faziam demonstrações, tinha uma brincadeira com isso também.

O curso funcionou durante nesse período muito espelhado na metodologia na estruturação que era na a escola evidentemente com uma carga horária menor, a gente trabalhava uma hora e meia, duas horas por dia e as aulas não eram todos os dias. Dávamos as vezes 4 dias de aula por semana eu acho.

Em algum momento a gente deu aula 3 dias, só dependia do lugar, mas era nunca assim... Só no começo que as aulas eram todos os dias depois a gente começou a alternar um pouquinho para a gente também ter um espaço para nós.

\section{PERGUNTA: Fale um pouco sobre a companhia de vocês, vocês chegaram a}

\section{formar uma, não?}

Foi que aconteceu, a companhia na verdade se chamou "teatro por um fio", e depois ficou como companhia do "teatro visível", a gente mudou assim e tal no meio do caminho, mas isso já pelo fim. As datas corretas... Eu teria que olhar tudo, porque eu não sei muito de cabeça como foi e quando aconteceu... Quando eu voltei da Inglaterra, logo que eu voltei Nadja foi chamada para dirigir um espetáculo, ela não queria dirigir nada, ela achava que não podia dirigir e tal, e Deborah era aluna dela, tinha sido aluna dela na escola de Teatro da UFBa e insistiu que ela devia dirigir e Maria Marighela, as duas tinham sido alunas na escola de teatro.

E elas tinham um projeto juntas. Elas queriam fazer alguma coisa juntas. Queriam fazer um espetáculo que fosse baseado em alguns autores e na verdade tinham um desejo de fazer alguma coisa com Clarice Lispector. E elas insistiram para que Nadja as dirigisse, ela ficou com muita dúvida e também ainda não existia o texto.

Tem uma estória ótima que é a seguinte: Elas tinham estudado com uma professora de literatura na escola de teatro e já lá tinham o desejo de adaptar um sopro de vida de Clarisse Lispector. Falaram com a professora... Ela foi e voltou, e no final das contas disse que não tinha como fazer aquilo e tal... Então Deborah disse: A gente quer fazer a gente vai fazer! E ela conta que durante o carnaval, e o carnaval aqui e um pouco longo, você sabe né? 
E durante o carnaval ela se trancou no quarto e em 15 dias ela fez uma proposta de texto, que na verdade é livremente inspirado no sopro de vida e tem referências tem citações... Chamaram o texto de: "Clarices", foi a primeira peça que Nadja dirigiu.

Eu cheguei da Inglaterra um pouco antes da estreia, talvez 3/4 meses antes. E eu entrei para trabalhar com assistente de direção. A gente trabalhava com a Nadja na preparação das meninas. E quando cheguei da Inglaterra, Nadja estava fez um projeto para trazer Steven e a Corinne, eles vieram para cá, eles vieram com a peça "Ressonance", que é um espetáculo duo onde eles faziam os duos amorosos do repertorio de Decroux.

E deram uma oficina, que foi lotadíssima, e uma conferência que está publicada na revista mimus ${ }^{50}$, é uma conferência que se chama Etienne Decroux e a mímica corporal. Então essa conferencia que ela deu esse ano que foi 1998, e quando eles vieram para cá, eles ficaram aqui 10 dias eu não me lembro, mas em torno disso, comendo moqueca todos os dias Corinne queria comer moqueca, todos os dias! E só não comeu moqueca no dia da apresentação do espetáculo, mas isso é outra história, e eles foram ver um ensaio de Clarisses e Corinne e Steven deram sugestões então tinha uma coisa realmente próxima assim, isso foi durante as férias, talvez julho, talvez agosto, algumas coisas assim, acho que Clarisses estreou em outubro, em setembro começamos a dar aulas.

Quando eu voltei, ainda estava fresco da escola com tudo na cabeça, também queria imediatamente fazer uma peça, queria fazer uma coisa que pudesse artisticamente entrar na cidade, e mostrar olha estou trabalhando a partir dessa linha, e fiz o solo "Francisco" que Nadja dirigiu com o texto de Deborah, que era inspirado, baseado livremente na vida de são Francisco de Assis. Eu queria na verdade não puxar pelo lado da santidade, mas o lado da vida do sofrimento das suas hesitações, suas dúvidas, tortura física, desse aspecto e a gente construiu a peça "Francisco".

No mesmo ano que "Francisco", no THEATRO XVIII, Nadja fez lá uma leitura dramática de uma carta de Artaud que ela tinha feito em um congresso de psicanálise, a equipe do XVIII propôs para dela transformar em uma peça.

E ela fez um solo, "todas as horas do fim" que era dirigido por Rita Assemany que é atriz, uma das idealizadoras do THEATRO XVIII, então ela fez esse solo que era a primeira parte com texto de Artaud e a segunda parte era com textos de Janis Joplin que foram adaptados por Aninha Franco.

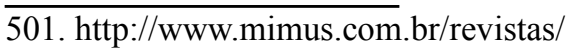


Então pronto, a gente tinha essas três peças, "Clarices", "Francisco" e "Todas as horas do fim".

Assim, durante muito tempo a gente teve várias pessoas que queriam trabalhar assim. Então, Maria Marighella e Laila Garin queriam fazer alguma coisas juntas, Nadja foi chamada para dirigir essa proposta que as duas fizeram juntas, que se chamou: "quando a cotovia voa", que era baseado no texto original que Deborah escreveu para elas que era um texto sobre a vida de Joana D'arc o texto original de Deborah se chamava "Joana D'arc" e a peça se chamou "quando a cotovia voa", porque tinha uma associação com a cotovia e tal, que era o apelido de Joana... E com inserção de poemas de Carlos Marighella... Teve essa releitura dessa peça...

Então estávamos com 4 peças em repertorio, Maria a essa altura estava começando a fazer as aulas de Mímica, um dia Maria e Deborah chamaram a gente para jantar e propuseram: porque a gente não monta um grupo? Tínhamos 4 peças e todo mundo já tinha se revezado de alguma forma, inclusive Maria que foi assistente de direção para "todas as horas do fim", então tinha esse jogo que a gente naturalmente estava fazendo entendeu?

Fazendo essas coisas e tal um pouco pela afinidade e tal, mas sem nenhuma formalização.

Então a gente resolveu fazer uma espécie de cooperativa, não era exatamente uma cooperativa inicialmente foi registrado inclusive como empresa e tal que era um núcleo solidário criativo.

A ideia é que a gente pudesse fazer uma rede de trabalho com outras pessoas. E passou muito tempo assim, gastando energia e trabalhando para criar uma rede de relações na cidade e etc. Além de manter evidentemente o curso, as oficinas que a gente fazia. Com uma certa dificuldade de produzir artisticamente, depois que a gente se formalizou, não conseguimos fazer outras montagens.

O que conseguimos fazer foi manter esse repertorio em cartaz, a gente fez isso muitas vezes inclusive a ida para o Festival de Teatro de Curitiba que foi uma das ações, depois que de fazer a temporada de "Clarises" aqui, fizemos no palco giratório... Também fizemos em duas ocasiões uma mostra do repertório no próprio THEATRO XVIII inclusive.

Então foram várias ações que foram feitas, mas a gente não conseguiu produzir uma coisa nova, exceto mais já no fim. Tem um diretor aqui em salvador que chama Filinto Coelho, que ele tem um projeto chamado: todo mundo faz teatro. Filinto a gente conhecia ele desde o tempo da escola do colegial, eu e Nadja. 
Ele também dirige peças e numa conversa, ele é muito amigo de Nadja, não lembro quem propôs, mas surgiu essa ideia de fazer uma peça dele, que seria adaptada para nos quatro na verdade esse texto ele usa para o curso dele e ele faz isso com 30 atores e tal, mas ele propôs uma adaptação em que nós fizéssemos todos os personagens da peça, dentro de uma possibilidade assim de troca de personagens etc.

E era um espetáculo musical com temática assim muito próximas da cultura da Bahia, a gente achou que poderia ser uma coisa bacana de fazer porque era um jeito também de fazer de lidar com a mímica dentro de uma outra roupagem

E ai a gente conseguiu um patrocínio na época, eu acho que pelo FAZ CULTURA (Lei Estadual de Incentivo da Bahia), não tenho muita certeza, acho que foi edital desses editais da Telemar enfim, de telefonia.

Antes disso para ocupar uma pauta que a gente tinha a gente fez uma coisa delicia, que era muito simples, mas que foi o que teve mais visibilidade nesta época por causa da temática.

Se chamava "sarau atrás do trio elétrico", a gente fez perto do carnaval, e era, na verdade, assim contando a história do trio elétrico, e éramos nós quarto e tinha um pouco de música e tal, e era algo muito elegante. E a gente contou com a participação de Aroldo Macedo que é filho de Osmar Macedo que é um dos criadores do trio elétrico. Ele fez a trilha do tigre essa última peça que estou fazendo, a trilha original a composição é dele, Aroldo, então o cara é incrível.

O sarau era assim: cada dia uma pessoa era convidada, um artista, cantor, para cantar trechos de música e coisas que lembrava e gostava. Ele (Aroldo) foi convidado um dia e disse que iria em todos... E foi a todos os saraus! Tocava guitarra Baiana e contava as histórias do pai e de Dodô, que é também um dos inventores do trio elétrico. E aí a gente fez isso até a estreia dessa outra peça que se chamava: "bloco dos infames".

E o "bloco dos infames" foi a última coisa que fizemos juntos... Quando acabou a temporada, acho que em novembro, em dezembro a gente entendeu que esse período de trabalho já tinha se resolvido... Digamos assim, que os desejos de cada um de fazer uma coisa diferente e cada um foi seguir o seu caminho... Então foi um pouco assim...

Para detalhes mais detalhados eu teria que olha com mais precisão recortes de jornal... A gente tem tudo isso... 


\section{PERGUNTA: isso merece um estudo somente disso!}

E exatamente, mas você sabe que estou escrevendo sobre isso... Sobre o que aconteceu aqui... Sobre essa entrada aqui...

Porque tem várias coisas que são importantes, inclusive tenho um trabalho que vai ser publicado que já dá uma indicação disso, tem as referências de Luís Otávio Burnier e tal, mas a primeiro, espetáculo baseado nesta linguagem, digamos assim, de alguém que retornou com esse treino foi "O banquete de Alice", peça de Nadja, a criação e dela dirigida por Elisa Mendes e eu fiz a assistência de direção na época, que foi na entressafra entre paris e Londres.

Tinha uma coisa que eras bem forte nesse sentido da experimentação da mímica... Era um espetáculo bem bonito... Então estou escrevendo sobre isso sobre esses espaços, entendeu?

Depois que eu vim para a UFBA eu cheguei à escola no momento que teve uma mudança de currículo e a gente precisava um conjunto de optativas e a minha chefe de departamento pediram que tivesse dentro do conjunto de disciplinas optativas as disciplinas de Mímica Corporal Dramática.

Então você tem hoje em dia duas disciplinas de Mímica Corporal Dramática, eu acho que não tem isso em nenhum outro curso, tem esse espaço aqui pelo fato desse trabalho que fizemos, desse tempo todo, espaços assim...

(*) George Mascarenhas é doutor em Artes Cênicas (PPGAC/UFBa), Mestre em Artes Teoria e História da Arte pela Universidade Federal da Bahia (1999), Formado em Mímica Corporal Dramática pela Ecole de Mime Corporel Dramatique (Londres)(1998), Licence de Estudos Teatrais pela Université de la Sorbonne-Nouvelle - Paris III (1995). Professor do curso de teatro da Faculdade Social da Bahia (2004-2010), prof. substituto no Bacharelado em Interpretação Teatral (2006) e Bacharelado Interdisciplinar em Artes (2010) da Universidade Federal da Bahia. Ator, diretor, professor e pesquisador, a partir da técnica de Mímica Corporal Dramática de Etienne Decroux. Coordenador da Mimus - Revista online de mímica e teatro físico. Professor Adjunto no Curso de Teatro da Universidade Federal de Sergipe (UFS) (2010-2014). Atualmente é Professor Adjunto na Escola de Teatro da Universidade Federal da Bahia. 
7.4 Entrevista com Ana Teixeira(*) - Julho de 2016.

PERGUNTA: Após vocês voltarem de Paris, era importante a questão pedagógica, vocês tinham o interesse em manter treinamentos regulares ou o foco principal era a companhia?

As duas coisas estavam intricadas, também trabalhando com uma técnica com um método específico, vocês precisam de pessoas que respondam às suas necessidades para poder dialogar na sala de ensaio, mas a pedagogia e criação para nós, com essa vida de grupo, desde então, são um único projeto.

Foi em 95 e 96 quando cheguei ao Brasil, era muito novo isso aqui, tinha um estranhamento das pessoas... Um engessamento... Desde então essa ideia de que a técnica e uma coisa importante para o ator na formação do ator, não e mais novidade, hoje isso está mais integrado, a gente compreende melhor a necessidade de um conhecimento maior de seu corpo, de um domínio maior do corpo do ator.

Enfim, havia um estranhamento muito grande naquela época as pessoas se surpreendiam com a proposta da oficina, que era uma oficina de teatro uma oficina para o ator e que dedicava muito, muito do seu olhar do seu cuidado ao trabalho corporal, não era tão comum....

A gente chegou e imediatamente começamos a dar aula na $\mathrm{CAL}^{51}$ que é uma escola aqui do Rio de Janeiro, então para nos foi a primeira experiência com ensino regular, e foi marcante até pela compreensão para gente de que aquele modo de transmissão não era o modo adequado para nós, na verdade, cada experiência em nossa chegada foi muito importante para apontar isso, porque a gente chegava com essa bagagem e a gente estava começando a fazer a transmissão disso...

Essa pergunta e só em relação as oficinas de mímica corporal, não é?

\section{PERGUNTA: Sim.}

A gente começou dando aulas em muitos festivais, O FIT de belo horizonte, depois a gente foi pelo ECUM, que acho que foi a oficina que você fez, todas essas oficinas foram muito interessantes porque elas se contrapunham a essa maneira de transmissão e logo pouco tempo depois, a gente teve uma sede e a gente teve a experiência de transmissão dentro da sede, então todas essas experiências forma igualmente importantes.

51 Casa das Artes de Laranjeiras - http://www.cal.com.br 
Temos a nossa sede desde de 2003, mas a gente passou a abrir para ter atividades a partir de 2004. Os primeiros anos dávamos cursos de mímica corporal, tinha essa intenção de não só treinar pessoas para poder trabalhar conosco, como o objetivo de formar pessoas de transmitir o legado.

\section{PERGUNTA: conseguiram formar?}

Sim, a Renata Colasso, por exemplo, que foi a minha primeira aluna, foi aquela que seguia todas as pequenas oficinas que a gente ia dando, que com quem a gente trabalhou dentro da companhia e que depois de trabalhar com a agente ela foi para Londres e entrou para ao Theatre De L'Ange Fou, foi uma pessoa bem formada por exemplo, eu diria.... Ela chegou formada la...

Mas depois disso outras pessoas, mas ai já não eram exatamente formadas em Mímica Corporal eram formadas em uma linguagem onde a Mímica Corporal tem um papel muito estruturante, estruturador.

\section{PERGUNTA: Como se deu no caminho de vocês essa transição partindo da} Mímica Corporal a dialogar com outras técnicas, vocês ainda mantêm uma base com a Mímica Corporal?

A gente tem, mas não tem um treinamento na Mímica Corporal, mas eu acho que nosso teatro continua muito ancorado num teatro decrouxiano, mais do que a técnica propriamente dita, mas a gente reelaborou muito desses princípios técnicos, mas em outras abordagens, em outras maneiras de abordar que foi se dando através de um método que a gente foi construindo que se chama: treinamento e improvisação, onde tem uma grande parte técnica onde os princípios e os elementos técnicos da Mímica Corporal são trabalhados e em outra abordagem...

\section{PERGUNTA: Essa transcrição foi por uma necessidade artística?}

Foi antes de tudo uma necessidade artística porque a Mímica Corporal é... Primeiro porque eu percebi rapidamente que não queria fazer um teatro separado, um gênero de teatro a parte do teatro, eu queria fazer teatro em toda a sua extensão e explorar essa casa em todas as suas possibilidades de linguagens, não via porque me aprisionar a uma única linguagem. 
E depois tinha um problema que eu via no entorno das pessoas que eram formadas na mesma técnica que eu, no mesmo teatro que eu, porque acho que viemos de uma tradição teatral, isso é muito forte, é mais que uma escola...

E eu via que havia um problema criativo porque havia um aprisionamento numa estética em uma linguagem que para mim colocava alguns limites. Então me confrontando a outras influências importantes que eu tive, que é o teatro do extremo oriente, que vem do teatro do extremo oriente e minha parceria com o Stephane Brodt que vem do Théâtre du Soleil, e tem uma presença muito forte do Théâtre du Soleil e da Ariane Mnouchkine em nosso trabalho...

Então a gente pode confrontar essa herança, vamos dizer assim, a outras visões e inserir esta tradição dentro desse universo maior, mais largo, em dialogo, em movimento... Então isso para mim foi muito importante porque isso completamente podia responder a busca que a Mímica Corporal por si só não tava respondendo...

Então sim, acho que foi por aí que começou eu acho...

Queria colocar em dialogo, e a primeira coisa que a gente fez como grupo também, talvez não por acaso... A gente foi montar o primeiro espetáculo, acho que começou na verdade...

Mas eu me dou conta que quando a gente foi fazer nosso primeiro espetáculo a primeira coisa que a gente fez foi colocar a técnica de Decroux em confrontação com o universo inteiro de Antonin Artaud, e estudando as relações que haviam entre eles historicamente, mas sobretudo esses olhares sobre o fazer teatro e sobre a técnica, da voz e do corpo, foi aí que começou...

“Cartas de Rodez", que fundou realmente nossa teatralidade, nosso campo de pesquisa com a Mímica Corporal inclusive.

\section{PERGUNTA: Esse período de oficinas de Mímica Corporal, você sabe quantas} pessoas passaram pelos cursos?

De número... Poxa, nunca fiz a conta, mas olha... Muita... Gente! Muita gente, porque eu dei muitas oficinas, eu dou menos oficina agora, mas ainda dou muita oficina, porque a pedagogia é uma parte muito grande de nosso trabalho, a gente dedica muito, muita da nossa energia, de nossa pesquisa e ela está completamente ligada ao nosso processo criativo!

Realmente... Muita gente, um dia ainda vou fazer essa conta! 
Se essa pergunta for só sobre a Mímica Corporal vai ter um número um pouco mais limitado, eu não tenho a preocupação de ser uma legatária da Mímica Corporal...

Eu acho que é a liberdade de explorar linguagens é próprio de nosso trabalho de criação, não sei, não vejo por que... Agora, mas eu também acho que uma única janela você pode abrir muitas coisas, mas isso e muito pessoal... São escolhas artísticas.

\section{PERGUNTA: Técnica é importante para o ator?}

Sim! A técnica é fundamental para qualquer atividade artística ou qualquer atividade humana, técnica ela é fundamental... E tem uma diferença entre a técnica e a formação do artista.

Transmitir uma técnica não e necessariamente formar um artista, hoje a minha preocupação é muito maior com a formação do artista do que com a transmissão de uma técnica específica ou uma técnica híbrida.

Mas a técnica sim ela e fundamental, ela que dá liberdade, amplia as possibilidades de expressão, traz as chaves para a compreensão das leis que regem nossa arte e das possibilidades de transgredir essas leis por ter domínio delas... E tudo mais...

Não claro o treinamento, ele é mais que um veículo só para a transmissão de uma técnica, treinamento também vincula outros valores que são importantes no dia a dia de um grupo, porque o treinamento envolve várias técnicas...

(*) Ana Teixeira é pedagoga, fundadora e diretora do Amok Teatro do Rio de Janeiro e diretora artística da Casa do Amok. No Amok Teatro ela dirigiu diversos espetáculos, apresentados no Brasil e no estrangeiro. Todos os espetáculos do grupo obtiveram um grande reconhecimento da crítica e do público e diversos prêmios do teatro nacional. Com Cartas de Rodez (1998) recebeu o prêmio Shell de direção, o Prêmio Mambembe de melhor espetáculo e a indicação pela direção. Com O Carrasco (2011), recebeu o Prêmio Governo do Estado do Rio de Janeiro de melhor espetáculo e a indicação pela direção. Dirigiu Macbeth (2004), Savina (2006), O Dragão (2008), Kabul (2009), Histórias de Família (2012) e Salina (2015). Com Stephane Brodt, dirigiu também os espetáculos: Memórias do Velho Mundo, O Dibuk e Agreste Malvarosa de Nilton Moreno.

Com trinta anos de experiência pedagógica nas artes cênicas, Ana Teixeira desenvolve uma pesquisa continuada sobre a arte do ator e ministra oficinas em escolas, universidades e festivais no Brasil e no estrangeiro. 
7.5 DVD - Multimídia 